\title{
Affecting Access to the Independent Media Arts: \\ Policy and Preservation Initiatives in Canada
}

\author{
by
}

Michele L. Wozny, MA Film Studies

MA thesis submitted to the Faculty of

Graduate Studies and Research in partial fulfilment

of the requirements for the degree of

Master of Arts

in Film Studies

\author{
Carleton University \\ OTTAWA, Ontario
}

First Submitted: June 26, 2009

(C) Michele L. Wozny, 2009 
Library and Archives Canada

Published Heritage Branch

395 Wellington Street Ottawa ON K1A ON4 Canada
Bibliothèque et

Archives Canada

Direction du

Patrimoine de l'édition

395 , rue Wellington

Ottawa ON K1A ON4

Canada
Your file Votre référence

ISBN: 978-0-494-60280-5

Our file Notre référence

ISBN: $978-0-494-60280-5$
NOTICE:

The author has granted a nonexclusive license allowing Library and Archives Canada to reproduce, publish, archive, preserve, conserve, communicate to the public by telecommunication or on the Internet, loan, distribute and sell theses worldwide, for commercial or noncommercial purposes, in microform, paper, electronic and/or any other formats.

The author retains copyright ownership and moral rights in this thesis. Neither the thesis nor substantial extracts from it may be printed or otherwise reproduced without the author's permission.

\begin{abstract}
AVIS:
L'auteur a accordé une licence non exclusive permettant à la Bibliothèque et Archives Canada de reproduire, publier, archiver, sauvegarder, conserver, transmettre au public par télécommunication ou par l'Internet, prêter, distribuer et vendre des thèses partout dans le monde, à des fins commerciales ou autres, sur support microforme, papier, électronique et/ou autres formats.
\end{abstract}

L'auteur conserve la propriété du droit d'auteur et des droits moraux qui protège cette thèse. $\mathrm{Ni}$ la thèse ni des extraits substantiels de celle-ci ne doivent être imprimés ou autrement reproduits sans son autorisation.
In compliance with the Canadian Privacy Act some supporting forms may have been removed from this thesis.

While these forms may be included in the document page count, their removal does not represent any loss of content from the thesis.
Conformément à la loi canadienne sur la protection de la vie privée, quelques formulaires secondaires ont été enlevés de cette thèse.

Bien que ces formulaires aient inclus dans la pagination, il n'y aura aucun contenu manquant. 


\begin{abstract}
Bereft of an adequate archival infrastructure, both the administrative history and the audiovisual output of the national network of the Independent Media Arts Alliance has been left to languish on the shelves of not-for-profit, artist-run centres across Canada. This thesis demonstrates that the absence of a national framework for the systematic preservation of independently produced audiovisual work is the result of the delimitation of federal cultural policy governing film and artistic practices, which has had a profound effect on the perceived archival relevance of work produced within distinct realms of cultural production, including the media artwork produced through funding from the Canada Council for the Arts. The lack of political will to provide the resources necessary to establish a cultural policy infrastructure with an archival framework that would accommodate the systematic preservation of independently produced audiovisual work has resulted in an acute preservation crisis within the independent media arts community.
\end{abstract}




\section{Acknowledgements}

The author wishes to express her thanks to the following individuals:

Paul Litt and André Loiselle (Carleton University)

Kelly Langgard and David Poole (Canada Council for the Arts)

Richard Lochead and Steve Moore (Library and Archives Canada)

Jennifer Dorner and Peter Sandmark (Independent Media Arts Alliance)

Douglas M. Gouthro

Thank you all; this would not have been possible without your generous support. 


\section{Table of Contents}

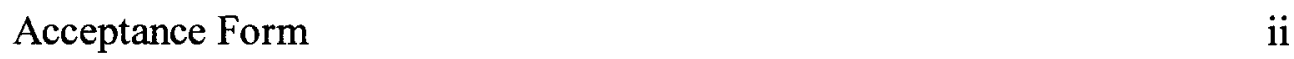

$\begin{array}{ll}\text { Abstract } & \text { iii } \\ \text { Acknowledgements } & \text { iv } \\ \text { Table of Contents } & \mathrm{v} \\ \text { Introduction } & 1-14 \\ \text { Chapter 1: } & 15-50\end{array}$

The Development of Federal Policy to Support Film Practices and the Arts in Canada

Chapter 2:

$51-89$

Policy Development within the Canada Council and the Creation of the Media Arts Sector

Chapter 3:

$90-123$

The Development of Federal Policy Governing Audiovisual

Archival Practice in Canada - Key Issues

Conclusions

$124-133$

Bibliography

$134-139$ 


\section{Introduction}

Why has it proven so difficult to secure a federal preservation infrastructure that would systematically archive publicly-funded media artwork in Canada? The growth and subsequent delimitation of federal cultural policy governing film and artistic practices has had a profound effect on the perceived archival relevance of audiovisual work produced from within distinct realms of cultural production, which has fostered a discourse that separates independently produced media artworks, such as those funded through the Canada Council for the Arts, from those works produced within industrial or educational frameworks that are likewise supported through government agency. This discourse is reflected in the developmental history of archival policy that has governed the preservation of audiovisual records in Canada and has resulted in a contemporary policy framework that does not safeguard an overwhelming majority of independent media artworks.

Bereft of an adequate archival infrastructure, both the administrative history and the audiovisual output from the entire national network of the independent media arts community has been largely left to languish on the shelves of not-for-profit, artist-run centres across Canada. And while the archival relevance of moving images themselves was initially suspect, which jeopardized the better part of the early audiovisual output produced by a disparate national community of independent producers, the aura of high culture that was attributed to and bred from within the Canada Council further placed at risk the incipient 'experimental film' that this agency would become mandated to support. Yet, Canadian federal policy would come to acknowledge the worth of other types of film and video-based work, 
eventually providing shelter for audiovisual records produced through the National Film Board (NFB), the Canadian Broadcasting Corporation (CBC), and more recently, Telefilm Canada. The output from the Media Art Sector at the Canada Council for the Arts has not been likewise protected. In fact, it has been the progression of a three-tired history of federal cultural policy development in Canada throughout the $20^{\text {th }}$ century, the growth of the film, arts and archival environments, which has shaped and affected the contemporary preservation crisis within the independent media arts community. ${ }^{1}$

Audiovisual preservation has at its roots a simple fact - all such work is technologically dependent, which amplifies its vulnerability across time. The very nature of most audiovisual records, written as they are by machines, means that the salvation of such work is inherently linked to the speed at which technology changes; as audiovisual equipment becomes obsolete, partnered content becomes unsupportable and must be migrated to newer formats that are contemporarily compatible. This is a monumental task for preservationists, taxing both human and financial resources and indeed, a vast quantity of video from only forty years ago currently exists on formats that are now virtually unplayable. ${ }^{2}$ And while in Canada

\footnotetext{
${ }^{1}$ The Canada Council changed its name to the Canada Council for the Arts in 1994, as part of an 'improved transparency package,' as Clive Robertson points out, yet both 'the Council' or 'the Canada Council' often take preference over the longer title. I, like Robertson, will use each of these titles interchangeably. Clive Robertson, Policy Matters: Administrations of Art and Culture (Toronto: YYZ Books, 2006), p. ix.

${ }^{2}$ Library and Archives Canada (LAC) is developing an Audiovisual Migration Action Plan to cover the years 2009-2014, within which 1/2" EIAJ, 2" Quad and 2" Helical tapes are ranked as 'extinct' while Betamax, reel to reel and cassette tapes are 'critically extinct' and $3 / 4$ " U-Matic tapes (once the industry standard) are considered 'endangered.'
} 
certain gauges of film have faired better than others throughout the $20^{\text {th }}$ century, ${ }^{3}$ the world at large is also witnessing the wide embrace of digital technology, which has quickly placed even the once ubiquitous array of $16 \mathrm{~mm}$ filmstock in jeopardy. ${ }^{4}$

This thesis, however, will not investigate the technological aspects that hinder the migration of audiovisual work, nor will it examine the various physical and administrative processes inherent to the archival preservation of audiovisual material so as to keep such records publicly accessible. Rather, this thesis turns its attention first and foremost to the history of Canadian cultural policy, as the evolution of such policy in the $20^{\text {th }}$ century has indelibly influenced and affected the contemporary preservation crisis within the independent media arts community. Not only do media artists need to know their own history in order to contextualize the work they themselves are producing, but Canadians also stand to benefit greatly from the remarkable record that these works document, an aspect of Canadian heritage that indeed evokes particular junctures of time and place within Canadian society. Yet without a commitment to systematically incorporate independently produced audiovisual work into the archival and preservation policies of a national cultural framework, the bulk of media artwork created by the vast network of independent Canadian producers cannot survive - there will be no trace of either the administrative or cultural history of the nation-wide independent media arts community.

\footnotetext{
${ }^{3} \mathrm{LAC}$ considers itself expert in the restoration of $28 \mathrm{~mm}$ film, for example.

${ }^{4}$ At the time of writing, only two Canadian labs remain open to the processing of $16 \mathrm{~mm}$ colour filmstock, Technicolour Vancouver and Niagara Custom Labs (Toronto). The Black and White Film Factory (Toronto) also specialized in black and white filmstocks.
} 
This thesis will therefore demonstrate that the absence of a national archival framework for the systematic preservation of independent media artwork is the result of a series of historical developments that run through three policy domains, which will be explored in three separate chapters. Chapter 1 addresses the slow advancement of Canadian federal policy over cultural affairs in the first half of the $20^{\text {th }}$ century, which relegated early film practices to government service and shied away from establishing structured policy for the arts. Chapter 2 then examines the interplay between arts activism and internal policy development, which led to the establishment of the Canada Council for the Arts (1957), the formation of the Independent Media Arts Alliance (1980), ${ }^{5}$ and then, the creation of the Media Arts Sector within Council (1983-84). Chapter 3 traces the evolution of audiovisual archival practices in Canada in relation to developments in both federal cultural policy and international archival policy, with a focus on Canada's national infrastructure. The current preservation crisis within the independent media arts community is, in effect, the result of a structured absence that is demonstrable through the combined historical weave of these policy threads, an absence that has neglected to provide the resources necessary for the accommodation of independently produced media art within archival environments.

\footnotetext{
${ }^{5}$ The Independent Media Art Alliance (IMAA) is a national network of artists and organizations who employ or service the use of film, video, audio and newer media within artistic practices. It exists primarily as a lobby group to address national policy issues that affect the health of the entire network and does not therefore examine matters that are otherwise governed by provincial or municipal policy. Member-groups within the network, which is most often referred to as 'the Alliance,' are predominantly supported at the organizational level by the Canada Council, where artists also earn grants to support individual works. And although most centres and many artists also receive provincial and municipal funding, few would be in practice without the base-funding provided through the Canada Council for the Arts. For further information on IMAA, please consult www.imaa.ca
} 
In conducting research for this thesis, it became evident that the bulk of the literature written on behalf of the independent media arts community concentrates on the aesthetics of the work itself, but not on the policy infrastructure from within which this community and its cultural contributions have emerged. It is only recently that critical writing has begun to focus on the political history behind the development of certain artist-run centres or organizations, ${ }^{6}$ and only a very select number of published works have addressed policy matters from within or around artist-run culture at the national level, such as the seminal text written by Clive Robertson. ${ }^{7}$ Much of the information within this thesis regarding the independent media arts community was therefore gathered through primary research at the archives of the Independent Media Arts Alliance (IMAA) in Montreal, which was then interwoven with information gleaned through research conducted at the Canada Council for the Arts and Library and Archives Canada (LAC). As the thesis situates the contemporary preservation crisis within the independent media arts community in relation to specific policy formation at the Canada Council and the development of an audiovisual archival environment at the national level in Canada, it will therefore serve to establish a core foundation for further scholarly investigation into the historic relationship of cultural policy and arts activism within the independent media arts community in Canada.

\footnotetext{
${ }^{6}$ For example, Making Video 'In': The Contested Ground of Alternative Video on the West Coast, ed. Jennifer Abbott (Vancouver: Video Inn Studies, 2000), or Kevin Allen, Sweet Sixteen: An Amble through the History of the Alberta Media Arts Alliance Society (Edmonton: AMAAS, n.d.).

${ }^{7}$ Robertson's book focuses on the Canada Council's Visual Arts Sector, not the independent media arts community, and while there is cross-over, especially in formative years, as yet there has been no thorough examination of how the history of the Independent Media Arts Alliance relates to policy formation at the Canada Council and/or the development of the Media Arts Sector.
} 


\section{Cultural Policy and Independent Media Art in Canada}

John M. Bumsted underscores two common usages of the word culture, distinguishable predominately by variance of purpose. Anthropologically used to describe constant social flux, culture embodies the values, beliefs and customs expressed amorphously by a people. In the words of Raymond Gagné, culture is therefore "a given people's particular set of preferences, predispositions, attitudes, goals: its particular way of perceiving, feeling, thinking, and reacting to objective reality." ${ }^{8}$ In this anthropological sense, to archive culture would be to reflect society; on a national scale, this would logically include the indigenous, grass roots, ethnic and regional communities of a country. One might consequently assume that any archival strategy that sought to document the cultural evolution of a nation would likewise embrace the histories of such communities, and in Canada, this would therefore include those contributions ensconced within IMAA, itself a nation-wide network of varied media arts organizations that exists within the broader expanse of Canadian and international artist-run culture. ${ }^{9}$

Alternatively, Bumsted concedes that culture can also be read as an ideological currency that is used by the intelligentsia and the state to refer to "the

${ }^{8}$ Raymond Gagné, "French Canada: The Interrelationship between Culture, Language and Personality," in Canadian History Since Confederation: Essays and Interpretations, B. Hodgins and Robert Page, eds. (Georgetown, Ontario: Irwin-Dorsey, 1972), p. 526.

${ }^{9}$ Much more will be said about the evolution of artist-run culture in Chapter Two, but for now a few words to contextualize the term. According to Clive Robertson, "The appearance of 'artist's spaces' was noted as a phenomenon in 1977, when the American periodical Artsnews observed, 'The spread of alternative spaces may well provide the stamp of identity for the seventies'." (p. 2) The author further suggests that he and Marcella Bienvenue each "contributed separate essays for ANNPAC/RACA's first Parallélograme Retrospective, 1976-77, which were the only texts of that time that incorporated the specific phrase 'artist-run centre'.." Robertson, p. 15. 
training and refining of the moral, intellectual, and aesthetic sensibilities. ${ }^{\prime 10}$ This conceptual framework, frequently referenced through value attributed to 'high' culture, has proven important to cultural policy arguments as Canadian governments have indeed attempted to fix a relatively homogenous identity upon a diverse populous through symbols and icons that carry common currency; as such, high culture folds into common myth and can be used to help bolster national identity. Value-laden divisions between high and low culture, embedded in subtle contradistinctions between 'films' versus 'movies' or 'art' versus 'entertainment,' emerged early in Canada and indeed influenced the formation of federal cultural policy. Such etymological intimation resulted in the development of discrete film practices that separated film communities, both from the arts and from each other, well into the second half of the $20^{\text {th }}$ century. This exacerbated the devaluation of certain types of film within archival circles and led to developments within archival policy that had grave historical consequences for the acquisition of certain kinds of audiovisual records within Canada's national institutions, which further jeopardized the preservation of contemporary media artworks.

This thesis situates emerging filmic practices and the growth of arts activism within the early framework of federal cultural policy development in Canada during the first half of the $20^{\text {th }}$ century so as to demonstrate how particular uses of film produced esteemed valuations, which in turn provided for the development of early preservation practices. As Chapter One unfolds, it becomes clear that the federal government of Canada was spurred to develop clearer film policy from the 1930s

\footnotetext{
${ }^{10}$ J. M. Bumsted, Interpreting Canada's Past (Toronto: Oxford Press, 1986), p. 399.
} 
onward as a result of convergent forces, both economic and social, that favoured a role for film as an educational tool for nation-building. Conversely, the governments of the day evaded formal policy development on behalf of the arts, and also largely ignored the role that film played in the sphere of public entertainment. Such federal policy (or lack thereof) was challenged, and subsequently informed, by increased activism on the part of filmmakers and artists, which eventually led to the demarcation of film activity as supported by the federal government, and the separation of art from industry.

It would be the release of the 1951 report from the Royal Commission on Arts, Letters and Science that urged the Canadian government to finally address the production of 'prestige' films, while it also advocated support for the 'voluntary selfhelp movements' in Canada through the establishment of a national arts council. With the formation of the Canada Council in 1957, the federal government, continuing to push for national unity, twinned culture with education. Ian Jarvie acknowledges that high culture defence strategies are often used by the cultural elite to "bring inchoate masses to accept the sense of nation and culture possessed by the elites." ${ }^{11}$ Further promotion of nationalism through a formal council for the arts would thus position the media arts community of Canada squarely within the realm of high culture. And henceforth, federal policy in the second half of the $20^{\text {th }}$ century actively implicated the cultural community in increased nation-building efforts.

\footnotetext{
${ }^{11}$ Ian Jarvie, "National Cinema: A Theoretical Assessment," in Cinema and Nation, Mette Hjort and Scott MacKenzie, eds. (London and New York: Routeledge, 2000), p. 80.
} 
Media artists, however, had aligned themselves with the aspirations of early remonstrations from community arts movements across Canada in the 1940s; although they desperately wanted a cultural policy infrastructure to better serve their work, they were much less interested in joining the ranks of high culture than in creating their own nation-wide community network. As Clive Robertson argues, "the manifestations of the artist-run culture movement in Canada has been widespread and enduring for many reasons aside from its existence within a particular conjuncture of nation-building through state funding."12 These activists did indeed govern the direction of the artist-run culture movement as they succeeded in establishing a set of strong, national lobby groups, from the early Canadian Federation of Artists and on through to the establishment of the Independent Media Arts Alliance.

Yet, as Foucault asserts and Robertson reiterates, we are all unavoidably 'politicized by policy ${ }^{\prime 13}$ therefore, one must question whether the self-governance of the independent media arts community, (in as much as this can exist within a national network of artist-run centres predominately funded through policy established by a federal agency), has itself a role to play in both the how and the who of power that has, to date, left the media arts without an archival infrastructure. For throughout the community-building process, as artists "expected themselves to be good administrators, artists, workers, and democrats," 14 they also became tools in the hands of their prime benefactor, the Canada Council. Indeed, Council continues to parlay

\footnotetext{
12 Robertson, p. 3.

${ }^{13}$ Robertson, p. iii.

${ }^{14}$ Robertson, p. $v$.
} 
the needs of the media arts community in service of Council's own attempts to increase funding to the (high) arts.

As Robertson goes on to state, "From Foucault we understand that ... while it is possible to work with government without working for government, it also becomes necessary to admit that, within such a working policy space, routine conflicts over authority and autonomy are not so easily dissolved." ${ }^{15}$ Certainly, artist-run centres have a role to play in assuaging their current archival predicament, given that their embedded agency within the Canada Council does indeed interlace with the ultimate, ethical responsibility that the Council itself ought have toward the preservation of media artworks that are created as a result of the support that Council is mandated to provide to this independent sector. Consequently, Chapter Two traces how policy developments within and beyond the infrastructure of the Canada Council have been influenced by the independent media art community itself.

Referring to more recent developments in Canadian feature film policy, Michael Dorland quotes, and comments upon, conclusions reached by L'Association professionnelle des cinéastes, addressed to the Canadian Society of Cinematographers in 1964: " Public taste is something which can be formed, or deformed, according to circumstances.' And in Canada, public taste had clearly been deformed by the American monopoly in feature distribution and exhibition: 'We have called the result cultural colonialism...",16 While this thesis does not specifically address feature film

\footnotetext{
${ }^{15}$ Robertson, p. iv.

${ }^{16}$ Michael Dorland, So Close to the States: The Emergence of Canadian Feature Film Policy (Toronto: University of Toronto Press, 1998), p. 123.
} 
policy, except as it entwines with archival issues or the development of policy that pertains specifically to the evolution of the independent media arts sector, certainly, from World War I through to the mid-20 ${ }^{\text {th }}$ century, an anti-American platform was adopted by activists and the federal government of Canada. Used as a cultural defence strategy, the stance has proved to be a powerful policy trigger, as pundits first attempted to solve sectarianism, then salve regionalism and promote a stronger sense of nationalism within Canada. Throughout the $20^{\text {th }}$ century, the nation-building argument has supported policy developments that sought to strengthen government film production, increase distribution and build audience. Yet as Chapter Three elucidates, the same argument did not extend to the provision of long-term policy on behalf of the preservation of Canadian audio-visual history, denying a framework for the systematic preservation of independently produced audiovisual records within the national archival infrastructure.

Chapter Three also explores the evolution of audiovisual archival policy in Canada in order to examine how governance policies from within the Canada Council have themselves played a role in the contemporary preservation crisis within the media arts community. A critique of the exact nature of the Council's involvement in the development of federal policy that has established the contemporary preservation infrastructure that now ministers to Canada's moving image heritage is critical to complete an understanding of how and why the crisis within the independent media arts community has evolved. For indeed, while IMAA continues to play a role in influencing a solution to the preservation crisis, "the social and cultural interventions 
and ambitions of artist-run centres are re-designated by funding agency policy."17 Any effective solution to the preservation predicament within the independent media arts community will require the political will of all parties.

Unfortunately, very few of the audiovisual works created in the independent media art sector over the past fifty years have been systematically preserved under appropriate archival conditions. Indeed, throughout the 20 th century, the political will necessary to maintain a cohesive and integrated federal strategy that would clearly delineate archival responsibility for such material has vacillated. The body of work produced through the NFB, however erratically preserved, has fared much better than that produced through the Canada Council, primarily because federal government policy had historically addressed the largely documentary output from the NFB, not as independent, but rather, as governmental, as "an object and instrument of administration by the state." 18 In Chapter Three, therefore, this thesis also demonstrates how developments in archival policy over independently produced audiovisual documents were founded upon early valuations of moving images, which led to demarcations that separated types of film practices in accordance with purpose (educational and industrial), and pitted them against cultural practices that evolved through 'experimental' high art or commercial 'entertainment' paradigms. For indeed, such historical practices and related federal policies have created a national audiovisual archive that reflects only a small part of Canadian moving image heritage.

\footnotetext{
${ }^{17}$ Robertson, p. 1.

${ }^{18}$ Robertson, p. iv.
} 
Artist-run centres, predated by co-operatives and collectives, are "multiplycoded and constructed as intermedia spaces for production and display practices, as material sites, and as loci for cultural and community activities." ${ }^{19}$ Therefore, the various media arts practices emerging from within artist-run centres are not monolithic: independent media artwork is produced in both analogue and digital formats; it can be documentary, experimental, animated or dramatic; it is short, midand feature-length, produced with technology in the form of new media, video, film, and/or audio; it can be exhibited in outdoor installations and may be transmitted via overhead, front or rear projections; it adapts to web-based, gallery or in-situ environments; and while some of it crosses disciplinary lines, single-channel films and videos are also regularly screened at festivals, seen on television or otherwise viewed or heard via new technology carriers. In this respect, the plethora of work produced by the independent media art sector does differ from that traditionally produced through government institutions, such as Telefilm, $\mathrm{CBC}$ or the NFB. ${ }^{20}$

Which begs the question: Does the reluctance of Canada's archival environment to embrace the systematic preservation of independent media art stem from difficulties that are more associated with how to archive the gamut of independent media artwork $?^{21}$ Or are there more fundamental issues that prevent media art from taking its place within Canada's national archival infrastructure?

${ }^{19}$ Ibid.

${ }^{20}$ While it is acknowledged that both the NFB and Telefilm have funded explorations into new media technology, financing both research and the production of media-based works that breach the traditional boundaries of the small and large screen, this work is the exception, not the norm.

${ }^{21}$ Although significant research on archiving media art is conducted at the Daniel Langlois Foundation (Montreal), this thesis maintains a national and federal focus that will not incorporate the private or provincial arena. Interested readers are encouraged to visit: www.fondation-langlois.org 
Would Canadian independent media artworks be better served beyond the national archival infrastructure? Such questions, of course, implicate the contemporary role of the Department of Canadian Heritage where provisions for a national framework and the distribution of preservation resources throughout Canada's cultural infrastructure are envisioned. And while important to the contemporary preservation crisis within the independent media arts sector, the historical approach of this thesis can only scratch at the surface of contemporary federal policies that have set current criteria to mete out meagre financial resources to and within Canadian institutions.

The exploration within this thesis into the evolution of three-tiered cultural policy development in Canada will help, however, to historically situate the current preservation crisis within the independent media arts community, and in the process, clarify why national archival repositories contain but a trace of their contribution to Canadian cultural heritage. Such an historical understanding is crucial to those who seek a successful strategy that would see the systematic preservation of publicly funded, independently produced, media artworks, such as those created through the grant programs that are supported by policy directives from the Canada Council for the Arts. 
Chapter One: The Development of Federal Policy to Support Film Practices and the Arts in Canada

Historians who write about early Canadian cultural history theorize a milieu that set divisions between high and low culture, divisions that are revealed in terminology that distinguishes between film and movies, between art and entertainment, indeed, between culture and industry. Since confederation, artistic practices within Canada have seen a range of political influences; from early arts patronage and the struggle to build cultural awareness, to the political use of culture to build the nation, Canadian politics moved through colonial bids for east-west unification, custodial debates defining provincial versus federal jurisdiction, and protectionism against American influence. The place occupied by independent filmmakers, indeed the very definition of independent as pertains to media production in Canada, has likewise shifted as a result of changes in political policy that came to govern cultural practice. It is the purpose of this chapter to trace early developments that led from an overall unwillingness on the part of the federal government to intervene in cultural affairs to an infrastructure that would begin to support film and artistic practices in Canada. This will place artistic film practice within the broader cultural landscape, and in the process, identify how federal policy both affected the metamorphosis of emergent filmmaking practices and also produced a federal institution responsible for the arts, one that would eventually embrace the independent media arts community within Canada. 
Early Beginnings

Research into support for the arts in Canada in the late $19^{\text {th }}$ and early $20^{\text {th }}$ centuries frames the evolution of early art practice within colonial government patronage. Largely applauding efforts by British representatives to Canada, Maria Tippett states: "From Confederation to the outbreak of the Second World War, Canada's viceroys did more than any other group within the public service to give direction to the country's cultural life... fulfilling what many of them considered to be their mandate: unifying the culturally diverse and geographically dispersed people of the Dominion through exposing them to the institutions, sentiments, and culture of Great Britain."22 Earl Grey, for example, stressed that the biggest danger Canada faced was ultimate disintegration, should the east and west not solve their 'regional orientation.' The arts, it was felt, could serve a useful purpose by fostering a sense of togetherness, of belonging, if the vastness of Canada, sparsely populated with a wide range of ethnicity, embraced English customs and values by adopting traditional English art practices. ${ }^{23}$

Canada's governors general felt that it was their duty to help the country take its place among the more 'culturally advanced' nations of the world, to help Canada

${ }^{22}$ Maria Tippett, “'A Mad Desire to Bring About State Control': Government Patronage and the Arts," Making Culture: English-Canadian Institutions and the Arts before the Massey Commission (Toronto: University of Toronto Press, 1990), pp. 63-64.

${ }^{23}$ Mary Vipond's research reveals that a "web of personal relationships and friendships ...linked together a 'network' of professionals, academics, business men, and other members of the English Canadian elite in informal patterns of communication." Mary Vipond, "The Nationalist Network: English Canada's Intellectuals and Artists in the 1920s," Canadian Review of Studies in Nationalism, Vol. 5.1 (Spring 1980), p. 34. 
through its 'rather crude and material stage." ${ }^{24}$ Tippett delineates that "the unusual practice, however, was not to bring in institutions from Britain, but to foster and encourage local ones." 25 She cites the activities of the Earl of Dufferin (1872-78), Canada's third governor general, as integral to the subsequent development of the Royal Canadian Academy of Arts (1880), while the efforts of Governor General Marquis of Lorne furthered the establishment of the National Gallery of Canada (1880) and the Royal Society of Canada (1882). Clearly, these Canadian institutions mirrored their British counterparts, modelled as they were on pre-existing cultural centres in the United Kingdom.

Unification through the development of a strong sense of nationalism was the political mantra throughout the First World War and well into the 1930s. Sir Wilfrid Laurier was a staunch supporter of the arts and according to Tippett's research, Laurier went on record as early as 1896 , stating that he wished to set up a system by which artists might receive 'monetary awards. ${ }^{, 26}$ By 1903, speaking to the Royal Academy of the Arts, Laurier announced "that he had been told by the minister of finance that there was now a surplus revenue of thirteen million dollars and he hoped the day would soon come when a portion of that sum could be devoted to the encouragement of Canadian art." 27 Tippett also lists tokenistic actions taken by several other prime ministers; in 1920, Arthur Meighan "presided over the opening of

\footnotetext{
${ }^{24}$ Maria Tippett , "The Origins of the Canada Council: 'The Most Generous Sugar Daddy Art Has Ever Known'," in Probing Canadian Culture, Peter Easingwood et al., eds. (Augsburg: AV-Vert, 1991), p. 39.

${ }^{25}$ Tippett, in Making Culture, p. 64.

${ }^{26}$ Tippett, in Making Culture, p. 70.

${ }^{27}$ Ibid.
} 
Carroll Aikin's Home Theatre in the Okanagan, ${ }^{28}$ while R.B. Bennett "provided for the construction of the Winnipeg Auditorium ... awarded knighthoods ... and made Lucy Maud Montgomery and tenor Edward Johnson officers of the Order of the British Empire. ${ }^{29}$ Further, William Lyon Mackenzie King spoke up on behalf of the arts when, as leader of the opposition in 1934, "he not only advocated that the government provide a building in which to house the National Gallery but suggested that a national theatre as well as a national opera might share the gallery's space in a building devoted solely to the arts." ${ }^{30}$ As such, there was early evidence of ad hoc political will to advance the arts in Canada, yet there remained no formal, regulated policy that would directly facilitate and administer to the needs of the arts community.

Audrey Forster argues that "the acceptance of artistic activity as an integral and important aspect of everyday life has been a slow process in Canada." ${ }^{31}$ What Forster underscores is not a lack of artistic activity; indeed he goes to great length to document "the tenacity and dedication shown by early artists, musicians, actors, and authors in their struggle to keep the arts alive." ${ }^{32}$ The critical point he makes, rather, is that beyond sporadic patronage, artists living in Canada during the first halfcentury after confederation could not make a living from their work. Given that there

\footnotetext{
${ }^{28}$ The Okanagan Valley is the south-central region of lake-linked land in southern British Columbia, originally settled by the people of the Okanagan First Nations.

${ }^{29}$ Tippett, in Making Culture, p. 71.

${ }^{30}$ Ibid.

${ }^{31}$ Audrey Forster. "From the CPR to the Canada Council," in A Celebration of Canada's Arts 1930-1970, Glen Carruthers and Gordana Lazarevich, eds. (Toronto: Canadian Scholar's Press Inc., 1996), p. 213. Emphasis mine.

${ }^{32}$ Forster, p. 213.
} 
was no unified cultural policy, no transparent and systematic means of bestowing monetary grants to either institutions or directly to artists, the arts community could not directly benefit from political suggestions that spoke of institutionalized acculturation.

Meisel and Van Loon point out: "As a British colony and Dominion, Canada was, during much of its formative period, under the cultural domination of its mother country. While English Canada undoubtedly benefited from the cultural links with Britain, they retarded the development of many indigenous initiatives and the training of Canadians capable of doing first-class work in the arts."33 With the exception of ad hoc gestures generally bestowed upon the upper echelon of the artistic elite at the whim of select officials, the government appeared less interested in fostering a healthy nation-wide artistic community than in using the arts to further the political goals of a British colony: east-west unification, the reification of outpost citizens, and the beautification of settlements.

\section{The Development of Independent Film Practices}

Interestingly, filmmakers are not included in Forster's list of 'early artists,' nor are they mentioned anywhere in Tippett's research into Canada's early cultural development. How then, did the filmmaking community in Canada evolve - how would certain filmmakers eventually come to see themselves as part of the artistic

\footnotetext{
${ }^{33}$ John Meisel and Jean Van Loon, "Cultivating the Bushgarden: Cultural Policy in Canada," in The Patron State: Government and the Arts in Europe, North America, and Japan, Milton C. Cummings et al., eds. (New York: Oxford University Press, 1987), pp. 282-83.
} 
community? It is documented that in June 1896, Montreal hosted the first public screening of a film in Canada, thus establishing early domestic exhibition practices as parallel to the dates of film premières around the world. Film also began to appear in vaudeville theatres across the country at this time as travelling showmen toured from city to city and country to country to showcase the marvel of a new technology, thus creating loose distribution circuits. Surviving sales catalogues and records from distribution companies of the era demonstrate the extensive number of works that migrated through world-wide circuits, including within Canada. The Canadian public therefore, had access to film from its inaugural beginnings. ${ }^{34}$

Films were also being made in Canada at the turn of the century: in 1897, three films were shot in Niagara Falls, for each of Lumière (France), Edison (United States of America), and Biograph (Great Britain), all foreign concerns. Notably, the bulk of very early films produced in Canada continued to be turned out by offshore companies, their contents either industrial or propagandistic in nature. The Canadian Bioscope Company, for example, was founded as a branch of Urban (Great Britain), with a mandate to make films for the Canadian Pacific Railway (CPR). Primarily advertisements to stimulate immigration to the west, the first CPR reels, Living Canada, were known as 'scenics' and they were distributed throughout Great Britain, although few Canadian citizens would have seen them at the time they were released.

\footnotetext{
${ }^{34}$ For example, from the paper trails left by American Mutoscope and Biograph, Kemp Niver composed the Biograph Bulletins 1896-1908, while Denis Gifford produced The British Film Catalogue 1895-1985: A Reference Guide; both are important chronicles of early film traffic. Canadian film historians, D. J. Turner and Micheline Morisset, have also compiled The Canadian Feature Film Index: 1913-1985, which is an invaluable catalogue for feature film scholars and curators as it documents, where possible, production dates and places, cast and crew, the location of inaugural premiere, and vitally, whether or not the films are still in existence and if so, in what format(s).
} 
Just as early art practices were touted as political tools for unification and nationbuilding, early films were also used, initially as promotional tools to help stimulate the Canadian economy.

Political propaganda began to emerge on screen in Canada as early as 1899 , when the government of Great Britain, intent on raising patriotic feelings in the colonies, commissioned Biograph to shoot footage of Canadian volunteers leaving Québec City for the South African Boer War. By WWI, under the governance of Prime Minister Sir Robert Laird Borden, ${ }^{35}$ Canada had joined Britain's Imperial War Office's Cinematographic Committee (1916), which was formed first and foremost to accommodate requests to shoot footage of the war. Also during WWI, the Canadian government appointed Max Aitken (Lord Beaverbrook) to oversee the output of early wartime films. Through the production of the Canadian Eye Witness war series, it was discovered that film could carry a powerful psychological message to both soldiers and the enemy alike. The apex of Aitken's influence on the Canadian film scene was within his role as Minister of Information to the Canadian government where he encouraged exploration of 'the film tag,' a two-minute moralistic war propaganda prototype that was screened before feature films; some popular examples included 'Save Coal', or 'Buy War Loans'. ${ }^{36}$ Gary Evans claims that this was the first wave in

${ }^{35}$ Borden ruled as a Conservative between 1911 and 1917 and then, as a Union Government representative until 1920. Prime Minister Borden also commissioned artists to go to the front during World War One and paint, and indeed, he spoke at the opening exhibition that showcased these works, which was held as the Canadian War Memorials Fund Exhibition.

${ }^{36}$ Gary Evans, John Grierson and the National Film Board: The Politics of Wartime Propaganda, 1939-1945 (Toronto: University of Toronto Press, 1984), p. 22. 
Canada's struggle to shake the matronly control of the British Monarchy, "to publicize its position as an independent nation expressing imperial solidarity."

Increasingly, American business also came to Canada to shoot dramatic films: "Canada did have a short-lived domestic feature film industry of its own ... between 1919 and $1923 \ldots$ the 'fruitful years' when a number of companies used Canadian settings, casts, and crews to turn out films that compared favourably with prevailing international standards." 38 Peter Morris has painstakingly traced the early development of Canadian film production from 1895-1939, and he identifies The Kalem Company as "The first American company to travel into Canada to film Canadian dramas on location." ${ }^{39}$ Kalem purportedly incorporated 'Canadian themes' into some movies, such as: The Cattle Thieves (1909) - a Royal Northwest Mounted Police drama; Her Indian Mother (1910) - "the story of a half-breed"; and, For the Flag (1911) - "the story of a French Canadian girl who defends the honor of the French flag." ${ }^{40}$ Although the exception, some Canadian-based companies also shifted their stylistic approach to move with the times. For example, CPR, who hired American and British companies to produce and distribute their films, "recognized that the 'interest' films it had sponsored in 1902-1903 could no longer reach the same numbers of people. Audiences had changed. Movie-goers wanted drama; routine travelogues would only bore them." 41

\footnotetext{
${ }^{37}$ Evans, p. 20.

${ }^{38}$ John Thompson and Allen Seager, Canada, 1922-1939: Decades of Discord (Toronto: Toronto University Press, 1985), p. 176.

${ }^{39}$ Peter Morris, Embattled Shadows: A History of Canadian Cinema, 1895-1939 (Montreal: McGill-Queens University Press, 1978), p. 40.

40 Ibid.

${ }^{41}$ Morris, p. 42.
} 
Morris claims that four Canadian production companies were established prior to WWI, although he is also careful to note that "American personnel were heavily involved in all four of the Canadian companies active in fiction film production before the First World War: The British American Film Company of Montreal (incorporated in July 1912); the Canadian Bioscope Company of Halifax (incorporated in November 1912); the Conness Till Film Company of Toronto (incorporated in April 1914); and, the All-Red Feature Company of Windsor (incorporated in July 1914)." ${ }^{, 42}$ According to Morris, it was the British American Film Company that produced the first short Canadian drama, The Battle of Long Sault, released in 1913, which was followed by "yet another Indian drama," Madeleine de Verchères, produced by Arthur Larente, "a Montreal pioneer distributor and exhibitor." ${ }^{43}$ The Canadian Feature Film Index lists Evangeline (1913) as the first Canadian dramatic feature film, a Canadian Bioscope production based on a Longfellow poem, its heroine a displaced Acadian. ${ }^{44}$ As Canadian audiences became increasingly receptive to dramatic work, the stylistic shift in form also brought with it the elucidation of stories that were felt to speak more directly to Canadian experience, and to Canadian audiences.

\footnotetext{
${ }^{42}$ Morris, p. 47.

${ }^{43}$ Morris, p. 48. The footnotes acknowledge a discrepancy in dates, citing both 1908 and 1914 as the release date; however, The Canadian Feature Film Index cites the production date as 1922.

${ }^{44}$ D. J. Turner and Micheline Morisset, Canadian Feature Film Index: 1913-1985 (Ottawa: Ministry of Supply and Services Canada, 1987), p. 1. These researchers identified a film as 'Canadian' if it was produced by an incorporated Canadian production company, regardless of cash flow or crew; further, Library and Archives Canada considers a film to be feature-length if it is over 60 minutes long.
} 


\section{Film Practices within Canadian Government Institutions}

As the independent sector began to evolve, the Canadian government continued to use film as a promotional tool, this time in the name of trade and commerce. Charles Backhouse writes a detailed account of early Canadian film history (1917-1941) that acknowledges that federal government officials were busy preparing to establish the first government sponsored film production centre. By Order of Council, September 19, 1918, the Exhibits and Publicity Bureau became "an organization for the taking of motion picture negatives, development of films therefrom and the making of lantern slides and still photographs." ${ }^{45}$ Backhouse also underscores that while American film companies brought in "large sums of American money in the course of their operations ... the government seemed unaware at the time of the need to protect the already unstable local feature film industry."46

An official press release highlights the government's perspective: "Publicity is a means to an end, and in the case of the Trade and Commerce department the inauguration of a motion picture bureau is the beginning of a publicity campaign to make Canada known, as she really is, at home and abroad."47 As Backhouse states, "The mainstay of the Bureau's production was the Seeing Canada series, a number of highly successful one-reelers extolling the nation's scenic attractions and industrial capacity from sea to sea." 48 It was, after all, the Department of Trade and Commerce that ran both the Imperial War Office and the new Exhibits and Publicity Bureau in

${ }^{45}$ Charles Backhouse, Canadian Government Motion Picture Bureau, 1917-1941 (Ottawa: Canadian Film Institute, 1974), p. 7.

${ }^{46}$ Backhouse, p. 13.

${ }^{47}$ Backhouse, p. 7.

${ }^{48}$ Backhouse, p. 11. 
post-WWI Canada; these were indeed trade films used to drum up business, be that through immigration or industry.

According to Backhouse, the Exhibits and Publicity Bureau was "the first such continuing government publicity unit in the world." 49 The new effort to centralize film production within one government department at the federal level was not popular, however, neither among other departments, who had already established their own production and distribution mechanisms, nor within the budding entrepreneurial private sector, who felt that such a monopoly robbed them of a good portion of their livelihood. Nevertheless, Backhouse suggests that the Bureau exceeded expectation (and budget) when in 1919, at the Trade Fair in Lyons, France, they were able to screen over 14,000 trade films, including Canadian-made industrial and travelogue films, clearly establishing a functional exhibition arena that supported federal government film production.

By 1921, shifts in personnel and a subtle reorganization of the publicity unit resulted in a newly named Canadian Government Motion Picture Bureau (CGMPB), formally established in 1923. Still under the purvey of the Department of Trade and Commerce, Deputy Minister O'Hara expanded with a new mandate that more clearly enunciated that, "The Bureau was established for the purpose of advertising abroad Canada's scenic attractions, agricultural resources and industrial development... Another purpose of the establishment of the Bureau is the distribution of Canadian pictures in Canada, as they afford a valuable educational medium by which one part

\footnotetext{
${ }^{49}$ Backhouse, p. 8.
} 
of Canada is enabled to know the other." ${ }^{50}$ In keeping with the post-WWI push for a renewed sense of nationalism within Canada, the new functional objective within the Bureau targeted the use of film as an educational tool. As such, early policy in support of Canadian film remained directed at works that were produced within and for the Canadian federal government. These films were to support inter/intra-national public relations; as such, self-sponsored film production became a tool to move federal government platforms. Cultural development was not seen as part of the film package beyond the loose educative mandate, cloaked as it was under the rubric of nationalism.

In 1920, the new director of the Canadian Government Motion Picture Bureau, Ray Peck, had already announced that "an indigenous feature film industry in Canada was out of the question and that Canada should seek to persuade USA producers to make 'Canadian-content' films." attitudes during the Twenties had much to do with official government policy towards the commercial film industry in Canada.,"52 Indeed, Peck goes on to state that "the rapid disappearance of the Canadian film industry can be explained more readily in economic than in artistic terms... Giant and predatory Hollywood studios devoured independent Canadian producers ... not because they were Canadian but because they were independent.",53

\footnotetext{
${ }^{50}$ Backhouse, p. 10.

51 Backhouse, p. 13.

52 Ibid.

${ }^{53}$ Thompson and Seager, pp. 176 and 177.
} 
Wyndham Wise cites 1922 as the year that "the vertical integration of the Hollywood film industry squeezed out ... Canadian producers." ${ }^{, 54}$ When the American owned Famous Players Canadian Corporation bought out the largest Canadian exhibition chain in 1923, independent Canadian filmmakers effectively lost control over the public face of film. ${ }^{55}$ As long as Canadian film continued to be seen as a tool to support trade, not a cultural product that in and of itself could be traded, the independent producer, like artists in general, took a back seat; neither would be supported by federal cultural policy in these formative years.

\section{Emerging Cultural Policy}

Tippett claims that in Canada, while certain government officials were "willing to support a small number of professional cultural producers and their organizations, they knew that for most Canadians ... [art] was a recreational activity that was not thought to require assistance." ${ }^{56}$ Although filmmaking was not widely thought of as a cultural product in Canada, even less, an artform, it was indeed a rapidly growing commodity in American entertainment business, and developing within a commercial framework that was quickly overtaking international cultural markets. But while the Canadian government's production of industrial trade film was

${ }^{54}$ Wyndham Wise, Take One's Essential Guide to Canadian Film, September, 2001, p. 40.

${ }^{55}$ In 1916, Adolph Zukor and Jesse Lasky amalgamated to form Famous Players-Lasky, a production and exhibition company that had Paramount Pictures as its distribution arm. In 1920, Zukor bought Paramount and also incorporated the Famous Players Canadian Corporation. Then, in 1921 the Canadian Motion Picture Distribution Association was created by The Motion Picture Producers and Distributors Association of America; by 1922, the largest Canadian exhibition chain, owned by the Allen brothers, went bankrupt.

${ }_{56}$ Tippett, in Probing Canadian Culture, p. 41. 
itself driven by business-like interests, the style of these films was not adjusting to public taste as they took on an increasingly pedantic undertone. And still, the work produced by struggling independents, including the dramatic shorts and features that were being produced, was ultimately deemed 'recreational,' and therefore inconsequential; it fell beyond federal jurisdiction, as was the case for all cultural activity. $^{57}$

Vipond lists the challenges facing Canada in the 1920s as follows: "the ebbing of population growth, the increasing cultural and economic penetration of the United States, the rupturing of the East-West unity of the old National Policy, still-simmering ethnic antagonisms, the acceleration of urbanization and industrialization, the breakdown of traditional morality - and with it all, the lingering colonial mentality."58 As federal attention turned toward these issues, some believed that increased communication across provincial boundaries, a Canadian mass-education of sorts, would best address the ills of the state. Much in keeping with the inward shift in the approach to distribution at the CGMPB, a pan-Canadian educational objective slowly became embedded in the discourse of the times.

According to Tippett, the federal government had not championed the arts for several reasons, first and foremost because culture was seen to rest largely within the

${ }^{57}$ Canadian entrepreneurs who managed to make early theatrical dramatic films, not to edify but to entertain, include: L. Ernest Ouimet, Le Feu qui brûle (1918); Harley Knoles, The Great Shadow (1920); Ernest Shipman, Back to God's Country (1919), God's Crucible (1920) and The Man from Glengarry (1922). Interestingly, R.B. Bennett and Arthur Meighen both invested in what is often cited as the turning point in Canadian cinema, Carry on Sergeant (1929), an expensive, silent, feature film, released in Toronto a month after the Canadian premiere of the talkies. See Thompson and Seager, p. 1.78 .

$$
{ }^{58} \text { Vipond, p. } 43 .
$$


purvey of education, and education was legally "a provincial matter over which the federal government had no jurisdiction." 59 Indeed, "the Canadian constitution clearly assigns education to provincial jurisdiction, and culture is considered by most provinces to be so intimately related that the provinces must have unchallenged responsibility and primacy." ${ }^{60}$ However, just as a heightened image of film materialized as a useful educational tool, a certain profile of the 'entertainment' film also gained footing with splintered advocacy across provincial jurisdictions. Laws were soon set to regulate film exhibition, for example, and film censorship boards were established, first in Ontario and Quebec (1912), then in Alberta, British Columbia, and Manitoba (1913). ${ }^{61}$ Furthermore, the Ontario Motion Picture Bureau was also created in 1917 , its primary mandate, education. Therefore, as it became increasingly difficult to finance Canadian films for the theatrical market, Canadian film practices now seemed destined to assert themselves within the realm of education.

By 1928 , as a result of both the deepening international flood of primarily American feature films and increasing pressure for aid from the independent film community, the Canadian government, under the leadership of Prime Minister Mackenzie King, supported a position taken by the British government. ${ }^{62}$ Jack Ellis describes the situation as follows: "The [Imperial] Conference, recognizing the value

${ }^{59}$ Tippett, in Probing Canadian Culture, p. 41.

${ }^{60}$ Meisel and Van Loon, p. 281.

${ }^{61}$ Morris, p. 55.

${ }^{62}$ William Lyon MacKenzie King was Canada's Liberal Prime Minister, in power from 19211926, then again in 1926 after a brief break for Conservative Arthur Meighen. When MacKenzie King regained power in 1926, he held office until 1930, losing to Conservative Richard Bedford Bennett before being reelected again for a final reign, 1935-1948. 
of films for propaganda purposes, whether direct or indirect, in connection with Imperial trade, as well as for other purposes ... recommends that attention would be devoted to establishing and maintaining contact between the different parts of the Empire in relation to film production with a view to the sharing of experience and the promotion of the production of such films as will best serve the interests of the several parts of the Commonwealth."63 On behalf of all Commonwealth nations, the United Kingdom ratified the Cinematography Film Bill at the Imperial Conference, and then began applying the Quota Act; tariff laws against the distribution of imported films sought to regulate the influx of foreign, especially American, productions and thus allow domestically produced films a chance to proliferate across Commonwealth screens.

According to the research of Kristen Thompson and David Bordwell, "The result was a sharp rise in the demand for British films ... A considerable portion of production, however, was devoted to making 'quota quickies' - cheap, short films that barely met the legal requirements for a feature."64 Within Canada, the Quota Act did little to augment authentic domestic film production, nor was there an increase in the exhibition of Canadian films in the long term. As long as Canadian filmmakers failed to get adequate financial support to produce independent dramatic films that could compete within Hollywood's studio infrastructure, they would not secure

${ }^{63}$ Jack D. Ellis, John Grierson: Life, Contributions, Influence (Carbondale: Southern Illinois University Press, 2000), p. 61.

${ }^{64}$ David Bordwell and Kristen Thompson, Film History: An Introduction (New York: McGraw-Hill, 1994), p. 266. 
theatrical releases to distribute and exhibit their own Canadian content to domestic audiences.

However, Canadians increasingly feared American domination over mass communication media; specific to radio, lobby groups such as the Canadian Radio League, formed by Graham Spry and Alan Plaunt, mobilized over 6,000 members. A sense of nationalism was implicit in their slogan, 'We have a choice between the state or the United States.' In 1929, the Aird Commission, Canada's first Royal Commission on Broadcasting, was created to examine the danger that American programming posed to Canadian culture, with the underlying premise that control over radio would help Canada build their nation. The issues addressed by Sir John Aird in the Royal Commission on Broadcasting were as follows: national input into programming; responsibilities of broadcasters to both the private and public sectors; subsidization of culture versus the protection of business interests; regulation of freedom of expression; long-term financing for the creation of a public national broadcasting company; and, debates over whether technology or programming should drive the industry. By 1929 , the recommendations from the Royal Commission on Broadcasting clearly favoured the establishment of a public broadcasting network and the British Broadcasting Corporation was the model recommended to Canada. ${ }^{65}$ Under an educative banner of national unity, a case was being made to link Canadians through federal cultural policy.

\footnotetext{
65 "The decision had been reached, said Bowman, because 'the drift under private enterprise ... would lead broadcasting on this continent into the same position as the motion picture industry has reached." Charles A. Bowman, editor of the Ottawa Citizen and fellow commissioner on the Aird Commission, quoted by Thompson and Seager, p. 182.
} 
Indeed, Vipond's research into the 1920s shows that initially both intellectuals and artists saw themselves primarily as nation-builders who were "performing the critical function of crystallizing community identity by dispensing meaningful symbols and articulating common goals." ${ }^{66}$ By the 1930s, such nationalists "felt a need for the elaboration and institutionalization of previously informal or nonexistent links. "67 Further, "class and leadership assumptions ... gave ordinary Canadians little role to play except as the consumers of nationalist propaganda." ${ }^{68}$ Focused activism, such as that materializing within the film and broadcasting communities, enjoined artists and intellectuals to create the impetus necessary to force the Canadian federal government to address cultural issues, which applied not singularly to radio broadcasting, or independent filmmaking, but also to the arts community at large. And although, as Tippett reports, the federal government had also kept the cultural community at arm's length because the government felt it "was not being given any direction as to what its role should be by the cultural community itself," ${ }^{, 9}$ the Aird Commission had attested the contrary. Canadians needed and wanted national governance over culture, not reactionary solutions in the aftermath of the advent of new technologies. Further, fundamental issues such as freedom of expression and debates over public-private subsidization had become keystones in the ensuing discussions over federal responsibility for culture.

\footnotetext{
${ }^{66}$ Vipond, p. 34.

${ }^{67}$ Vipond, p. 43.

${ }^{68}$ Vipond, p. 46.

${ }^{69}$ Tippett, in Probing Canadian Culture, p. 42.
} 
By the 1930s, the Canadian public had indeed given the federal government a mandate to wrestle for more control over Canada's ability to build itself in its own image; only a national arm could reach across the country and with concerted effort, pull cohesive policy together. For the film community, this meant that by 1931 , Prime Minister Bennett, under the Federal Combines Investigation Act, appointed Peter White to ascertain the full affect of the monopoly of the Famous Players Canadian Corporation over the motion picture industry in Canada. A case was brought against Famous Players by the provinces of Saskatchewan, Alberta, British Columbia and Ontario; heard by the Ontario Supreme Court, without jury, the case was lost in March of 1932. In increasing numbers, the Canadian people at large were pressuring the federal government to increase its jurisdiction over cultural matters that clearly could no longer be salved with piecemeal provincial policy.

\section{The National Film Board of Canada}

When, in 1937, Ross McLean, then private secretary to the Secretary of State for External Affairs, Vincent Massey, filed a report on behalf of the Canadian film community, he urged "sweeping changes in policy and personnel in London and in Ottawa." ${ }^{70}$ McLean had travelled frequently to London and as a film enthusiast, he was well aware of the kind of Canadian Government Motion Picture Bureau films that were being distributed through Canada House. The style of montage travelogue and industrial films still being made at the Canadian Government Motion Picture

\footnotetext{
${ }^{70}$ Backhouse, p. 25.
} 
Bureau was seriously outdated, which was coupled with the fact that there were not adequate sound facilities at the Bureau that might accommodate this major technological advance in the industry.

McLean also understood the negative impact that the ineffectual Quota Act had had on Canadian and British film production, exhibition and distribution. Once popular domestic shorts had now been replaced by American double features, which "cut deeply into the market for the shorter Canadian films." ${ }^{, 71}$ And, McLean was also connected to the British documentary film movement, which by the mid 1930s was very strong; the movement had attracted international attention with novel storytelling platforms and an increased emphasis on location filming that portrayed the gritty reality of the everyday English. McLean recommended that John Grierson, an activist at the forefront of the new documentary film movement, conduct an independent survey of Canada's film holdings and distribution activities abroad. Grierson had been a producer within the Film Unit of the Empire Marketing Board in Great Britain and had travelled to Canada in the course of this work. When the Empire Marketing Board closed in 1933, Grierson's film production team was also hired to establish a Film Unit at Great Britain's General Post Office, which regularly held film exhibition events. As such, they hosted international film notaries such as Moholy-Nagy, Paul Hindemith, D.W. Griffith, Josef von Sternberg, Len Lye, Eisenstein and Robert

\footnotetext{
${ }^{71}$ Backhouse, p. 14.
} 
Flaherty; Grierson was no stranger to the artistry and innovation of film production on the international stage. ${ }^{72}$

Forsyth Hardy writes that while canvassing Canada in order to write up his report for Prime Minister MacKenzie King, Grierson spoke to a wide array of people across the country: newspaper editors, politicians, scholars and civil servants. "On one point they were all agreed: that the film should be used to diminish sectionalism and give Canada a sense of its relationships at home and overseas." ${ }^{, 73}$ Clearly, Grierson was determined that filmmaking remain propagandistic, essentially educational, and thus, separated from the entertainment industry. ${ }^{74}$

When he delivered his report to the federal government in June 1938, Grierson "stressed the need for coordination between all phases of policy, production and circulation, and urged the distribution of all Canadian publicity films be routed through one competent agency., ${ }^{, 75}$ In 1939, The National Film Board of Canada Act

\footnotetext{
${ }^{72}$ Grierson was also a Rockefeller scholar who travelled extensively through the United States; he had backstage access to Hollywood and also met the highly influential theorist, Walter Lippmann. Like Mackenzie King, Grierson much admired Lippmann's work and believed in his theory that society required management, specifically, manufactured consent, therefore it was bequeath to any government to support its people by giving them the information needed in order to make guided decisions.

${ }^{73}$ Forsyth Hardy, John Grierson: A Documentary Biography (London: Faber \& Faber, 1979), p. 93.

${ }^{74}$ There is also evidence of highly artistic, short-form, dramatic Canadian work made in this era, such as the Canadian Cameo series, produced by the Associated Screen News (ASN). Le Ballet des ondines (Ballet of the Mermaids), for example, was released in 1938; it is a hand tinted, $10 \mathrm{~min}$. film, with voice over, and was shot on nitrate filmstock. It can be viewed on the website of Library and Archives Canada, via Virtual Silver Screen, www.collectionscanada.ca/silverscreen. The short was directed by Gordon Sparling and produced by B.F. Norrish, the latter formerly a private producer for the Essany Film Unit. Norrish had also worked for the Trade and Commerce branch of the Canadian government before he headed up the film unit within the Exhibits and Publicity Bureau in 1917. According to Ted Magder, ASN "maintained a processing laboratory that prepared the positive release prints in Canada for all but one of the American companies. ASN was a profitable operation..." Ted Magder, Canada's Hollywood: The Canadian State and Feature Films (Toronto: University of Toronto Press, 1993), p. 27.

${ }^{75}$ Backhouse, p. 27.
} 
was passed and with the establishment of the National Film Board of Canada, the Canadian Government Motion Picture Bureau would be absorbed by 1941. Grierson took over at the helm of the NFB with a mandate 'to help Canadians in all parts of Canada to understand the ways of living and problems of Canadians in all parts.' Although this was by now a familiar refrain, it was the first time that the social education of Canadians had been so firmly planted into the hands of a stand alone federal institution geared exclusively toward filmmaking. As such, public discourse around education and culture coalesced with that of nation-building.

It is also important to note that the Government of Canada financed the NFB with an independent budget. "By its constitution, the Film Board has more direct power probably than any other film-propaganda organisation among the United Nations."76 Jack Ellis underscores that Grierson developed this type of administrative structure as a result of his experiences in England from both within the Empire Marketing Board and the G.P.O. Film Unit, so as to "eliminate the waste of energy and public money represented by Treasury governance of every detail of expenditure and employment... [it was] a deliberate attempt to secure the freedom necessary to creative work and creative people but still within a framework of public responsibility."77 As creativity also became part of the plan, the government of Canada was becoming increasingly involved in cultural affairs at the national level, albeit through sponsorship of a federal institution that would soon use film as an unwavering tool of propaganda.

\footnotetext{
${ }^{76}$ Ellis, p. 126.

${ }^{77}$ Ibid.
} 
While Grierson himself continued to make clear distinctions between 'movies' (entertainment) and 'film' (educational documentaries), he also insisted upon high production values and the development of an artistic element at Canada's new documentary film production centre. As such, the NFB went on to make laudable films that reaped rewards and garnered international acclaim. Churchill's Island won an Academy Award in 1942; War Clouds in the Pacific was released only days before Pearl Harbour; the Canada Carries On series launched with worldwide distribution; the first French language films at the NFB were produced for a national circuit; and, significant domestic distribution systems were established through regional film libraries, which began showing and renting NFB productions across an essentially rural Canada by 1943.

Yet aside from the exquisite anomaly of the Animation Unit, the NFB continued to exist to document. As Grierson himself would state, "I took on cinema as a pulpit, and used it as a propagandist and this I put unashamedly because, in the still unshaven philosophies of cinema, broad distinctions are necessary. Art is one matter, and the wise, as I suggest, had better seek it where there is elbow room for its creation; entertainment is another matter; education, in so far as it concerns the classroom pedagogue, another; propaganda another, and the cinema is to be conceived as a medium like writing, capable of many forms and many functions." 78 Thus, even as many Canadian filmmakers now found themselves working within or directly on behalf of a federal institution, and primarily involved in producing

\footnotetext{
${ }^{78}$ Ellis, p. 93.
} 
nationalistic, educational propaganda, their directed purpose was to make film with high production values. But indeed, film as 'art', would not have much elbow room within Grierson's NFB.

\section{Arts Activism}

Meanwhile, the sheer magnitude of Canadian artists had swelled and this group of cultural producers, aware of the zeitgeist, also began pushing hard for their own space, and for federal attention. Maria Tippett states that during the Second World War, Canada's cultural community "now saw themselves not simply as nationbuilders, educators, and beautifiers but as custodians of the values that Canada and her allies were struggling to preserve." 79 Artists, some of whom worked within the NFB institution, had also become active in the war effort, but given that there were now fewer resources, far less philanthropic patronage and concurrent government cuts to the National Gallery and CBC programming of arts and music, artists were propelled to organize. There was the creation of the Labour Arts Guild in Vancouver, the Writers', Broadcasters' and Artists' War Council in Toronto, the Seven Arts Club in Montreal, and the establishment of a national organization, the Canadian Federation of Artists - all are testimony to what Audrey Forster affirms as "the first stirrings of widespread discontent ... within Canada's artistic community." ${ }^{80}$ Forester claims that the publication of the Canadian Review of Music and Art (1942-1948)

\footnotetext{
${ }^{79}$ Tippett, in Probing Canadian Culture, p. 43.

${ }^{80}$ Forster, p. 217.
} 
spurred artists to further action, ${ }^{81}$ especially when that journal published an announcement of the opening of the Québec-based Institute of Music and Dramatic Arts, reporting statistics that clearly evidenced the uneven spread of provincial support for the arts. ${ }^{82}$ As early as 1942, "the Review was calling for the formation of a federal ministry of fine arts." 83

Paul Litt argues that by the end of WWII, "a confident and ambitious Canadian nationalism had grown out of the great accomplishments of the nation in World War II." ${ }^{, 84}$ Yet while post-WWII Canada certainly "experienced an exponential growth in its cultural activities," ${ }^{, 85}$ Meisel and Van Loon argue that this was largely because "educational systems had to adapt to the changed circumstances and did so in part by offering courses which were deemed suitable for generations which would enjoy more leisure... Arts and crafts courses proliferated and attracted large numbers of students ... There was also a substantial growth in the number and size of universities which professed fields of study in culture and the arts." 86

When a large group of artists, critics, educators, and curators from across the country met at Queen's University for the Kingston Conference of the Arts, they were part of the first such gathering of its kind in Canadian history. "During the four-day conference in June 1941, they discussed art and democracy, government sponsorship

\footnotetext{
81 Ibid.

${ }^{82}$ In 1942 , over $\$ 620,000$ was spent on the arts by the province of Québec, while Ontario

${ }^{83}$ Forster, p. 218.

${ }^{84}$ Paul Litt. "The Massey Commission as Intellectual History: Matthew Arnold Meets Jack
} divulged only $\$ 50,000$. Kent Cooke," Canadian Issues/Themes Canadiens: Practicing the Arts in Canada, Vol. XII, 1989, p. 25.

\footnotetext{
${ }^{85}$ Meisel and Van Loon, p. 277.

${ }^{86}$ Meisel and Van Loon, p. 279.
} 
of the arts, and the artist's role in the war effort." ${ }^{87}$ By June of 1944 , a group of twelve national cultural organizations had come together to collectively write the 'Artists' Brief. ${ }^{88}$ This coalition of activists, who would shortly form the Canadian Arts Council, ${ }^{89}$ next proceeded with what is known as the March on Ottawa (1945), where the 'Artists' Brief' was filed before the Special Committee on Reconstruction and Re-establishment, also known as the Turgenon Committee. Principally, the document demanded that the government establish a federal body to minister to the arts, more specifically, that a "non-political board be established to dispense public aid to the arts." $" 90$ The brief called for a nation-wide system of community art centres, a government publishing house, a national library and, finally, a reorganization of the existing cultural agencies, including the CBC and the National Gallery of Canada.

Tippett writes that, “The 'Artists' Brief' was a remarkable document because it set forward a plan that allowed for the co-existence of amateur and professional, national and local, alike. Implicit in it was the belief that by supporting practicing amateurs, intelligent audiences, and professional superstars, the government could build a strong cultural life." ${ }^{91}$ Further, as Paul Litt documents, "Artists were

\footnotetext{
${ }^{87}$ Tippett, in Probing Canadian Culture, p. 44.

${ }^{88}$ The organizations were: Royal Canadian Academy of Art, Royal Architectural Institute of Canada, Sculptors Society of Canada, the Canadian Society of Painters in Water Colour, Canadian Society of Painters, Etchers and Engravers, the Canadian Group of Painters, the Canadian Society of Graphic Artists, the Federation of Canadian Artists, the Canadian Authors' Association, La Societé des Ecrivains Canadiens, the Music Committee, the Canadian Society of Landscape Architects and Townplanners, the Dominion Drama Festival, Canadian Handicrafts Guild, Canadian Guild of Potters, and the Arts and Letters Club.

${ }^{89}$ The Canadian Arts Council, formally established in 1945, is now known as the Canadian Conference of Arts. It still operates as a national umbrella organization, although its former status in the 80 s, as "the most powerful and effective cultural lobby in the country" has diminished somewhat. Meisel and Van Loon, p. 281.

${ }^{90}$ Forster, p. 218.

91 Tippett, in Probing Canadian Culture, p. 45.
} 
concerned about their marginal status in Canadian society and impressed with how Roosevelt's New Deal in the United States had provided government support for artists through its Works Progress Administration." 92 Hence, three chapters of recommendations filed with the Turgenon Committee "dealt with a federal agency that would become the centre of cultural activities... including proposals respecting most federal cultural agencies, copyright, and tax measures affecting the arts and the artist." ${ }^{93}$ Under the umbrella of the Canadian Arts Council, artists were now actively working with a mandate to make the arts a creative factor in the national and regional life of Canadians, and artists themselves an integral part of society. ${ }^{94}$

Thus, developments within the film and broadcasting community, coupled with the advocacy that resulted from the Kingston Conference, had provided the Canadian government with a clear mandate from its citizenry to now justify federal 'interference' in cultural affairs. Further, in as much as the BBC was used as a model for the CBC, the establishment of the British Arts Council (1945) had also provided the Canadian federal government with a model upon which to develop a national cultural arts agency. For while the Canadian government had previously discussed and rejected European arts council models that had been established on church and aristocratic patronage because they were felt to be subservient to elitist high culture,

\footnotetext{
${ }^{92}$ Litt, "The Massey Commission as Intellectual History," p. 23.

${ }^{93}$ André Fortier and Paul Schafer, Development and Growth of Federal Arts Policies in the Arts, 1944-1985 (Ottawa: Department of Communications, May 1985), p. 9.

${ }^{94}$ It is generally accepted that the impetus toward communal resources had its roots in the Community Arts Centre movement, which was indeed present in both Canada and Great Britain. Dot Tuer writes, "Artists in the 1940s were as concerned with decentralizing culture as a system of community arts centres as they were with recommending the establishment of a government body to supervise cultural activity that would become the Canada Council." Quoted in Robertson, p. 18.
} 
the government had also dismissed the adaptation of American foundation models for much the same reasons.

Then, with the formation of the Security Council of the United Nations and Canada's post-WWII membership in North Atlantic Treaty Organization (NATO), Canada, within its new role as a member of the United Nations Educational, Scientific and Cultural Organization (UNESCO), found itself a player on the international cultural stage. It had now become essential that Canada, like all member states, organize and participate in UNESCO through a ministry of art and culture. The federal government could no longer back away from the challenge put forth, the challenge to create a national infrastructure that would provide support to the arts in Canada.

\section{The Royal Commission on National Development in the Arts, Letters and Science}

With some of the pieces now firmly in place, Liberal Prime Minister Louis St. Laurent, though still wary of federal interference in provincial cultural arenas, launched the Royal Commission on National Development in the Arts, Letters and Science in 1949, announcing that it was "in the national interest to give encouragement to institutions which express national feeling, promote common understanding and add to the variety and richness of Canadian life, rural as well as urban." 95 This Royal Commission, more commonly known as the Massey-Lévesque Commission, released its findings and recommendations two years later, in 1951,

\footnotetext{
${ }^{95}$ Prime Minister St. Laurent, quoted by Tippett, in Probing Canadian Culture, p. 47.
} 
after touring the country and gathering masses of information from individuals and groups involved in the arts and industries, those involved in the production and promotion of Canadian culture. ${ }^{96}$

Forster analyzes the results of the Massey-Lévesque Commission from the old public relations platform when he states the following as a principal finding: "Canada lagged far behind the other industrialized nations in cultural exchanges... there was, it was learned, no central body to which the Department of External Affairs could turn for expert guidance in the shaping of Canada's image abroad." ${ }^{, 97}$ According to Tippett, however, the report from the Massey-Lévesque Commission was "proBritish, anti-American, and anti-materialist ... an elitist moral vision of culture, ...(that) left little room for Canadians other than those who belonged to the British and French charter groups. ${ }^{998}$ Indeed, the cultural defence strategy implicit within the report placed the 'high' arts within an ethos of nationalism that still lingers within the cultural sector.

Film was specifically addressed within the report from the Massey-Lévesque Commission (henceforth referred to as the Massey Report), in two separate chapters, Chapter IV: Films in Canada, and Chapter XIX: The National Film Board. Generally, the Commission reported that in terms of independent film production in Canada, "the cinema is not only the most potent but also the most alien of the influences shaping our Canadian life. Nearly all Canadians go to the movies; and most movies come

\footnotetext{
${ }^{96}$ For an in-depth analysis of the Commission and the Report, see Litt, The Muses, the Masses and the Massey Commission (Toronto: University of Toronto Press, 1992).

${ }^{97}$ Forster, p. 221.

${ }^{98}$ Tippett, in Probing Canadian Culture, p 47.
} 
from Hollywood... [which] refashions us in its own image."99 The Massey Report went on to state: "The documentary film, for all its popularity and increasing use, still represents only a minute fraction of total film consumption in Canada. For general film entertainment, Canadians want commercial features; and in this field there is practically nothing produced in Canada ... although developments in feature films Canadian in character are taking place in Québec."100

Citing that there were only 20 independent film companies in the country, the Massey Report further acknowledged the plight of the independent producer, stating it was "essential that production by private companies be encouraged." ${ }^{101}$ Hence, in one specific recommendation, the NFB was "to continue its policy of commissioning films from private producers... [and] increase its efforts to co-operate with private producers and to encourage private film production." ${ }^{102}$ Thus, although acknowledging the lack of an infrastructure to support the production of independent film, the Massey-Lévesque Commission was not offering a solution to the predicament of 'recreational' film; rather, it was pitching continued support for the NFB, for educational, short-form, documentary-style productions. The Massey Report also affirmed "general agreement that the activities of the Board in the distribution, production, procurement and evaluation of films, and in research and experimental

${ }^{99}$ Report from the Royal Commission on National Development in the Arts, Letters and Science, Ch. IV: Films in Canada, p. 50. This report will subsequently be referred to as the Massey Report.

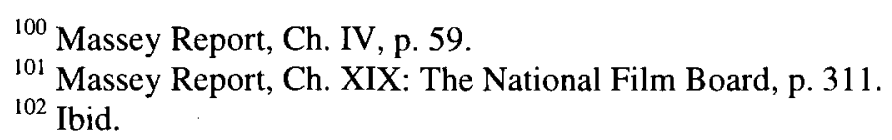


work, should be developed and expanded. These activities, we think, are rightly regarded as an essential service of public information."103

However, within the chapter on the NFB, under the separate heading, Research and Experiment, the Massey-Lévesque Commission detailed "the need for facilities in research and experiment ... in view of the expected requirements of television broadcasting in Canada in the near future." ${ }^{104}$ The production of 'experimental' film, which was implicated within this context, was thus addressed in reference to distribution models afforded by technology, i.e. television. And while the Massey Report affirmed that the private sector was indeed capable of producing such 'experimental work,' as private producers were "kind enough to show us some excellent films they had produced," ${ }^{105}$ the report also acknowledged that the NFB had likewise produced 'warmly praised' work of this nature. Further, "one of the reasons for our belief that the National Film Board should continue to produce films... [is that] only the National Film Board has at its command the equipment and resources necessary for sustained research and experiment." ${ }^{106}$ Thus, even as the MasseyLévesque Commission tied the dearth of independent production to a lack of resources, which prevented independent filmmakers from being able to research and experiment with film as their medium, it also saw the NFB as the primary site for such 'experimental' production, the outlet for which would be broadcast television.

\footnotetext{
${ }^{103}$ Massey Report, Ch. XIX, p. 307

${ }^{104}$ Massey Report, Ch. XIX, p. 311.

${ }^{105}$ Ibid.

${ }^{106}$ Ibid.
} 
Importantly, the Massey Report also acknowledged the existence of what it called "prestige films." It appears as though there was sufficient criticism from across the breadth of the country regarding the pedantic subjectivity inherent in most NFB productions to merit this attention. In support of private production, the report contrasted the ideology behind NFB films, "the delicate task of reconciling the didactic purposes of the sponsor with the creative instincts of director and producer," 107 against the freedom of films such as "have been produced in cooperation with a board of review representing the [National] Film Society and four other national organizations interested in adult education." 108 The Massey Report not only highlighted the production of such 'prestige' film, but also acknowledged the cooperation between "self operating film circuits," a community-driven distribution system that had helped circulate film across Canada. ${ }^{109}$

Formed post-1945 in reaction to budget cuts at the NFB, community-based distribution circuits had kept films flowing into rural areas. As the Massey Report acknowledged, "a similar voluntary self-help movement"110 existed in more densely populated areas, which allowed for the formation of "groups of individuals interested in seeing films [that] formed themselves into film councils."111 At the time of the writing of the Massey Report, there were purportedly 250 such film councils in Canada representing over 6,000 different organizations. The National Film Society of Canada (NFS), for example, had been founded in 1935, "to encourage the study and

\footnotetext{
${ }^{107}$ Massey Report, Ch. IV, p. 56.

${ }^{108}$ Massey Report, Ch. IV, p. 58.

${ }^{109}$ Massey Report, Ch. IV, p. 54.

${ }^{110}$ Ibid.

${ }^{111}$ Ibid.
} 
appreciation of the technique and art of the motion picture through the private showing to its members of selected films of an artistic or experimental nature."112 In order to foster a national film circuit, "the main target groups for the NFS services would be: the provincial departments of education and the universities; adult education groups; technical groups (requiring specialized films); and cultural groups. ${ }^{, 113}$ The Society opened eight municipal branches, in Montreal, Ottawa, Kingston, Toronto, Hamilton, Edmonton, Calgary and Vancouver. Clearly, while there were not many independent Canadian production companies, by the mid- $20^{\text {th }}$ century, clustered production and significant distribution activity indeed existed at the community level, led by activists who both produced film and developed appreciative audiences for such 'prestige' work.

\section{The Canada Council}

After the release of the Massey Report, which indeed advocated "the establishment of a 'Canada Council for the Encouragement of the Arts, Letters, Humanities and Social Sciences, ${ }^{, 114}$ the Canadian Arts Council, along with all of its member groups, worked hard to call attention to the issues that continued to face the average Canadian artist. The goal was to "press the government for a Canada Council," $" 115$ and in 1954, a cabinet committee was indeed established at the federal

${ }^{112}$ Yvette Hackett, "The National Film Society of Canada, 1935-1951: Its Origins and Development," in Flashback: People and Institutions in Canadian Film History, ed. Gene Walz, (Montreal: Media Text Publications Inc., 1986), p. 137.

${ }^{113}$ Hackett, p. 140.

${ }^{114}$ J. L. Granatstein, "Culture and Scholarship: The First Ten Years of the Canada Council," Canadian Historical Review, LXV, 4 (Toronto: University of Toronto Press, 1984), p. 441.

${ }^{115}$ Litt, The Muses, the Masses and the Massey Commission, p. 235. 
level in order to review the feasibility of creating such a federal cultural institution.

Given the complexity of provincial jurisdiction over educational-cultural affairs, a post-war paranoia that seemed to associate mass culture with communism, ${ }^{116}$ debates over a perceived inadequacy of existent cultural institutional models, and the overreaching notion that arts culture was by nature elitist, little would have been achieved without $\$ 100$ million of death duties left by Izaak Walton Killam and Sir James Dunn. Supportive politicians were, however, able to convince the decisive powers at large that in the public eye, this extraordinarily large sum of money would produce the best results for the government by tying culture to Canada's failing post-secondary educational institutions. ${ }^{117}$ Hence, $\$ 50$ million went into a University Capital Grants Fund, and the remaining \$50 million set up an Endowment Fund for the Arts, "whose earnings would support a programme of grants and scholarships for the arts, humanities, and the social sciences to be administered by a body to be called the Canada Council."118 The Canada Council Act was passed on 15 February, 1957, and via Bill 47, the efforts of the cultural community were rewarded with the establishment of the Canada Council for the Arts.

${ }^{116}$ Litt states, "The Cold War had made intellectuals and the general public alike acutely concerned about the meaning of liberal democracy and the need to defend it against rival political ideologies... Mass culture was to be feared because it seemed so closely related to the propaganda employed by both communist and fascist totalitarian regimes." Litt, The Muses, the Masses and the Massey Commission, p. 249.

117 Tippett claims that Privy Office economic advisor Maurice Lamontagne is said to have advised St. Laurent to invest the funds into arts and education. (Tippett, "The Origins of the Canada Council", p. 49). Granatstein writes that John Deutsch, Secretary of the Treasury Board, and J.W. Pickersgill, Minister of Citizenship and Immigration (former political adviser to MacKenzie King and St. Laurent), first suggested this split to Lamontagne, who had long been campaigning for an arts council. Granatstein, p. 441.

118 Tippett, in Probing Canadian Culture, p. 50. 
Claude Bissell wrote that for artists in Canada, a "new age had dawned ... the days of poverty and self-justification were over." ${ }^{, 19}$ In terms of the history of the media arts, however, much more activist work would be necessary before any such new age as may have dawned for visual artists, for literary artists or for musicians, would allow for the organized support of 'prestige' or 'experimental' film work. Film would not immediately take its place in the Council stable - in fact, it would take several more decades of hard lobbying by artists before a space would be made for media art within the structure of the Canada Council for the Arts, as will be acknowledged in the following chapter. As federal policy on behalf of film in Canada developed over the next 50 years, it would eventually provide increased clarity and distinction for the formative arms that now separated film-as-education from film-asentertainment and thus, ever so slowly, federal policy would also enable the Canada Council for the Arts to fully embrace independent media art, as these independent practices came to distinguish themselves from other types of government supported filmmaking activities.

Through the lens of cultural policy, this chapter's investigation into the early history of Canadian film practices and the developing activism within the arts community has referenced the political, the economic and the social, for film culture "encompasses the whole environment in which films are made, distributed, seen and discussed, and in which they create meaning." ${ }^{20}$ Discourse during the first half of the

${ }^{119}$ Granatstein, p. 444.

${ }^{120}$ Carole Sklan. "Peripheral Visions: Regionalism, Nationalism, Internationalism," in Film Policy: International, National and Regional Perspective, ed. Albert Moran (New York: Routeledge, 1996), p. 236. 
$20^{\text {th }}$ century separated filmmaking from artistic practice, as the multi-purposed needs of a young Canadian society grew in face of technological developments that were revolutionizing the world. Understanding these formative years helps build a more holistic picture of early Canadian film culture as this indeed informed the further development of federal cultural policy and directed how future policy would grow to include film, and later video, as an arts practice that would become supported within an arts council framework. Critically, as this thesis will demonstrate in Chapter Two, the further understanding of historic cultural policy developments and the arts activism that enabled the emergence of a Media Arts Sector at the Canada Council for the Arts also permits a more accurate assessment of the environment that has given rise to the current audiovisual preservation crisis within contemporary Canadian society. 


\section{Chapter Two: Policy Development within the Canada Council and the}

\section{Creation of the Media Arts Sector}

The refinement of federal cultural policy in Canada in the latter half of the $20^{\text {th }}$ century advanced in tandem with the steady evolution of artist-run culture, a nonprofit movement that actively promoted, and indeed prospered from, deepening policy developments within the Canada Council. And with direct input from the burgeoning and increasingly vocal, multi-disciplinary community of media art practitioners, the Canada Council's commitment to media art culture would broaden in an osmotic exchange with the expanding network of non-profit, artist-run centres it served. Yet as the Council originated the foundation of its own internal policy, which would evolve to eventually encompass film and video practices, it did so within a progressively delimited federal framework that circumscribed film activity. In order to better understand the position of the independent media arts community in relation to the wider context of Canadian film culture, this chapter traces federal support for both the film and the arts communities in the second half of the $20^{\text {th }}$ century, most specifically, where such policy development has affected the establishment of the Independent Media Art Alliance (1980), and the Media Arts Sector within the Canada Council for the Arts (1983).

As has been outlined in Chapter One, the appeal for the creation of cultural infrastructure that would support and cultivate artistic activity in Canada had been building steadily throughout the first half of the $20^{\text {th }}$ century, and this was formally iterated within the final report from the Royal Commission on Arts, Letters and Sciences (1951). Yet according to Maria Tippett, the major failing of this report was 
attitudinal, in that "believing that 'amateurism' was a problem to be overcome ... The Report ignored the community centre idea set forth in the 'Artists' Brief' of 1944.",121

Thus, while the original mandate of the Canada Council, articulated in the Canada Council Act of 1957, stated that the Canada Council was "to foster and promote the study and enjoyment of, and the production of works in, the arts, humanities and social sciences," 122 it was the evaluation of what constituted a work of art that hung in the balance.

\section{Formative Policy Debates within the Canada Council}

Early years at the Canada Council were marked by the struggles of any new organization: the establishment of a secure location; ${ }^{123}$ employment of personnel; and of course, policy development. Including the Director, Dr. Albert William Trueman, ${ }^{124}$ four permanent staff were initially hired to administer the bequeathed funds, which were equally apportioned into a University Capital Grants Fund and an Endowment Fund for the Arts. ${ }^{125}$ All of the 19 original Council members were

${ }^{121}$ Maria Tippett, in Probing Canadian Culture, pp. 47-8.

${ }^{122}$ Frank Milligan, "The Ambiguities of the Canada Council," in Love and Money: The Politics of Culture, ed. David Helwig, (Ottawa Ontario: Oberon Press, 1980), p. 61. Note: the Canada Council Act was revised in 1985 - see http://laws.justice.gc.ca/en/C-2/text.html.

${ }^{123}$ Canada Council's original interim offices were handed down by Louis St. Laurent himself, as parliament had just dissolved and an election campaign was under way. J.L. Granatstein, p. 445.

${ }^{124}$ Trueman had been the president at the Universities of Manitoba and New Brunswick, and he also held positions at the National Film Board as the Government Film Commissioner and Chairman (between 1953 and 1967), in addition to becoming the first Director of the Canada Council, a position he held from 1957-1965. His initial colleagues at the newly formed Canada Council included: Associate Director, Eugène Bussière; Lillian Breen, Secretary of Council; and a stenographer, who is not named. Milligan, pp. 445-446.

${ }^{125}$ This thesis will not directly address issues that affected the administration of the University Capital Grants Fund, except where such policy intersects with the establishment of the Arts Division; indeed, the educational sector was formally cleaved from Canada Council to form the Social Sciences and Humanities Research Council in 1977. 
appointed by the federal government through order-in-council, with staggered years of service to ensure fluid turnover. ${ }^{126}$ Initial growing pains necessarily focused on the establishment of clear policy for the two main branches, policy that would minister to each the arts and educational arm of the Canada Council.

According to Jack L. Granatstein, the original governing councillors had more political experience than arts experience, and it is said that the Council members relied heavily upon Trueman's advice. ${ }^{127}$ To compensate for a lack of first-hand knowledge in arts management, the councillors sought advice from the Rockefeller, Ford and Carnegie Foundations, all of which cautioned that the Canada Council would not see any noticeable results in their quest to support artistic excellence for five to ten years; they also forewarned of direct pressures from prospective clients within the arts community itself. ${ }^{128}$ Indeed, the Council would have to not only balance the needs of its two client bases, cultural and educational, but of necessity, also create policy that would redress federal-provincial tension over jurisdictional control of these two domains, and hence, face some of the repercussions of regionalism inherent in Canadian politics.

Political debates over Council policy on cultural equity issues that breached provincial jurisdiction arose fairly quickly. In 1960, George-Henri Lévesque referred to the Council as a "bicultural and bilingual institution" as he pushed for linguistically

${ }^{126}$ The inaugural board was established to ensure that at any given time each province was represented, in addition to properly balanced representation 'in the Canadian tradition,' which in 1958 translated into four women, four Anglophone, and four Francophone councillors. Granatstein, p. 446. p. 448.

127 "In the early years every request for money carried Trueman's assessment." Granatstein, 128 Ibid. 
balanced adjudication of requests for funding. ${ }^{129}$ Lévesque expressed concern that "French Canadians were not getting their fair share of scholarships...," and stated that Council "should provide roughly one-third of its assistance to French Canada." Within the confines of the initial expectations of the federal government, the new Council was indeed to inspire and promote nationalism through its arts and education policies. The pressure Lévesque exerted, "to promote federal spirit and friendly understanding between our two ethnic groups, ${ }^{, 131}$ resulted in the establishment of a Special Committee on Scholarships, which extracted the first comprehensive nationwide statistical data from within the Canada Council. Granatstein claims that the initial figures were inconclusive on the point of favouritism, although he also states that "when awards were categorized by region, Ontario did better than it should have in proportionate terms, the Maritimes got its just desserts, that the West did not, and that Quebec ordinarily did well.,"132

Ensuing policy discussions within Council highlighted the potential ramifications of political interference in Council affairs as the institution strategized how best to position itself as an organization that would operate independent of provincial-federal manoeuvring. To establish just such a policy platform, Director Trueman issued the following statement in 1963: "[Council] makes no attempt to distribute the income of the Endowment Fund in accordance with provincial or regional population." ${ }^{.133}$ The initial strategy at Council was rather to begin its work by

\footnotetext{
${ }^{129}$ Granatstein, p. 469.

${ }^{130}$ Ibid.

${ }^{131}$ Ibid.

${ }^{132}$ Granatstein, p. 470.

${ }^{133}$ Ibid.
} 
increasing audiences across Canada through the promotion of artistic excellence within already professionalized arts: "We believe that our resources should go to the support of full-time professional artists and organizations that are likely to achieve some degree of national prominence and to efforts to create an audience for first-class performances. ${ }^{\prime 134}$ As such, Council would continue to support a granting mechanism that rewarded on the principal basis of artistic merit, which stemmed from the foundation model of arts management that the councillors themselves had studied; it was a position that essentially supported the promulgation of a taste culture for the elite, and thus, quite contrary to what artists themselves had tabled within the 'Artists' Brief' of 1944.

Ian Jarvie describes a policy process that justifies the preservation of an elite cultural community as a cultural defence used strategically to ward off the overwhelming anthropological advance of 'local enculturation processes. ${ }^{135}$ Unsurprisingly, given the vast expanse of the arts community, regional disparity and the discrepant needs of multiple artistic disciplines, the Council was quickly challenged by growing activism within arts-based co-operatives, collectives and societies, which had already called into question meritorious sponsorship. The arts community had spoken deliberately in the 'Artists' Brief' and as artists continued to organize through the Canadian Arts Council, they sustained the call for support of a Canada-wide network of artistic centres, so as to foster higher quality work of course,

\footnotetext{
${ }^{134}$ Claude Bissell, quoted in Granatstein, p. 450.

${ }^{135}$ Jarvie, p. 83.
} 
but also to enable the emergence of progressively more and more talent from across the country.

Susan Crean writes, "artists all over the world (not just in Canada) have for years questioned the dubious practice of certifying artists [as] performed by critics, dealers, art directors, administrators, patrons and all the other art officials... We should be cautious about any limits that are used, particularly those involved in the pursuit of "excellence" - which is often the most arbitrary and capricious of all." ${ }^{136} \mathrm{~A}$ strengthened community of activists, who were much less interested in materialistic rewards for artistic merit and the continuation of philanthropic patronage that supported only the professional elite, instead called for support for an increased breadth of artistic activity across a networked arts environment.

The Canada Council realized that it was essential that its policy portrayed an organization that remained objectively balanced between the dichotomies of localnational, individual-organizational, and federal-provincial. ${ }^{137}$ And as Council struggled to balance itself between such competing interests, the Third Annual Report of the Canada Council (1960) asked: "Should money be used essentially to raise the standard of the arts ... or should it be devoted to spreading whatever arts there may be as widely as possible among the people?"138 Although early councillors had indeed supported 'raise' over 'spread', the organization now began to question this policy. Milligan speaks to the issue as 'the antinomy between enjoyment and production, use

\footnotetext{
${ }^{136}$ Susan Crean, quoted in Milligan, p. 64. Original emphasis by Crean.

137 Jarvie, p. 83.

${ }^{138}$ Milligan, p. 70.
} 
and creation, consumers and producers." ${ }^{139}$ Essentially, Council would have to decide how to increase funding for localized and individual production, risk the encroachment of 'local enculturation,' and also continue to develop and support preexisting artistic practices. ${ }^{140}$ By 1961, the Canada Council's Annual Report had already articulated "that part of its income from the Endowment Fund which it can devote to the arts belongs in a sense to the artists themselves... It is the Council's function to ensure that the funds are awarded in a way that may be expected over the years to do the most good. To determine what in fact will do good the council therefore turns to the artists among others for advice." 141

As the Canada Council worked to develop a system of governance that moved away from any appearance of favouritism or cronyism, it struggled to create policy that would effectively establish an arm's length decision-making process that would free Council from direct pressure, both from its nation-wide, arts-based clientele, and from the political parties of the day. For although the Canada Council was established "to operate as an arm's length institution, independent of government direction and interference," $" 142$ even in its early, financially independent years, Council was never

${ }^{139}$ Milligan, p. 61.

${ }^{140}$ Granatstein gives a detailed account of Canada Council involvement in the three ballet companies, which exemplifies the overriding meritorious and centrist attitude toward artistic practice circa 1957. He analyzes a commissioned report by Kenneth Le Mesurier Carter, a chartered accountant, as follows: '“As a long term investment for Canada,' Carter said, 'this company [National Ballet] should be supported until it is self-supporting on tour.' The two other companies were less important in Carter's Toronto-centric approach: they should be encouraged to tour their regions, they could live on modest budgets, and before any increase was made in their grants, 'their achievements and plans should be reviewed."' Granatstein, pp. 456-7.

${ }^{141}$ Milligan, p. 63. Emphasis by Milligan.

${ }^{142}$ Mary M. Johnson, "The Federal Government and the Politicization of the Canada Council: Exploring the Fine Line Between Accountability and Interference." (Master's thesis, Carleton University, 2000), p. 1. 
far from federal sight. Milligan states: "The government was frequently reminded of the Council's existence by the necessity of appointing new members to the governing body." 143 So while Council strategized how best to rationalize an appeal for direct annual funding from the federal government, which between 1957 and 1963 was under the Progressive Conservative leadership of John Diefenbaker, Council would also come under increased scrutiny. To create a workable relationship that established distance between itself, as an autonomous bureaucracy, and the federal government, whose influence would wax and wane with shifts in party governance over the decades, Council needed clear and firm internal policy that would irrefutably establish the arm's length arrangement under which it was originally conceived.

The Council therefore developed so as, "not to impose its own standards of taste, leaving the setting of standards to its advisers and juries drawn from the ranks of artists themselves,"144 and thus, the groundwork was laid for what would become a peer adjudication system of 'due process. ${ }^{145}$ By adopting the 'arm's length' jury-bypeer mechanism, Canada Council established a defensible system that "summed up the notion that the council should concern itself, not with forming its own judgment of the merits of an application, but with defining and overseeing the process by which it was to be judged by the peers of the applicant." ${ }^{146}$ As such, each jury of peers was

${ }^{143}$ Milligan, p. 71.

${ }^{144}$ Milligan, p. 64.

145 The exact date when the very first peer jury was established within Council remains elusive, however for more information on the history and evolution of the arm's length principle as it is used internationally as a public policy tool to administrate arts funding, readers are encouraged to consult The Arm's Length Principle: An International Perspective Past, Present and Future, Research and Evaluation, (Ottawa: Canada Council, 1985).

${ }^{146}$ Milligan, pp. 64-65. 
hand picked by Council Officers, who remain responsible for striking the appropriate balance for each adjudication session according to the priorities of the day: juries were then to be bilingual, regionally equitable, and later, gender balanced, culturally sensitive, etc. ${ }^{147}$

Clive Robertson states that, "for the Canada Council to remain an arts council and not a ministry of culture in disguise, decisions made by the Canada Council can only be legitimated by peer assessment and review. Such legitimations remain reliable as long as we acknowledge that the process of identifying 'peers' will produce a contested space." 148 So while it has been acknowledged that "artists judging artists, though far from a perfect system, is the best there is,"149 it is also clear that through this process, artists became reciprocally embedded in Council affairs. Canada Council, on the other hand, can in turn maintain its reputation as an agency that leaves its public face impartial. Through jury-by-peer due process, Council remains better able to answer to incrimination, both by governments and artist-run culture at large, and is therefore freed from meddling, in that it can claim to have no overt hand in the creation of taste culture, but rather, functions as an administrative bureaucracy.

${ }^{147}$ Depending on the program within the Arts Division, some Canada Council Officers remain able to award unique discretionary grants, although this is the exception, not the rule.

${ }^{148}$ Robertson, p. vii.

${ }^{149}$ Milligan, p. 65. Cited from a 1978 report, The Future of the Canada Council, submitted by the Arts Advisory Panel, which was established by Council in 1965. 


\section{Secretary of State}

Forcier and Schafer report that when Lester B. Pearson replaced Diefenbaker as Prime Minister in 1963, the new Liberal government immediately set about organizing a centralized framework that would see all cultural organizations reporting directly to one minister within one portfolio, that of the Secretary of State. "This structural change was defined in an amendment to the Department of State Act and was to have considerable repercussions on future federal cultural policies: without naming it as such, the government had established a Department of Cultural Affairs, with a minister who was to devote most of his time to the development of the arts in Canada.",150

Prior to this, the Prime Minister had directly received reports from the Canada Council and in turn submitted them to Parliament, while Public Archives Canada, the National Film Board, the National Gallery and the National Library of Canada were all accountable to the Minister of Citizenship and Immigration, but national museums were the responsibility of the Minister of Northern Affairs and Natural Resources. Now entrusted with co-ordinating the ongoing development of a holistic cultural policy framework for Canada, the offices of Secretary of State reported directly to the Priorities and Planning Committee of the Cabinet. And while such plans and priorities for the offices of Secretary of State were being established, Prime Minister Pearson decided to extend another $\$ 10$ million to the Canada Council, largely because of the wide expansion of Canada's university network and the "perceived necessity to staff

${ }^{150}$ André Fortier and Paul Schafer, Development and Growth of Federal Arts Policies in the Arts, 1944-1985 (Ottawa: Department of Communications, May 1985), p. 18. 
the universities;"151 indeed, a major study was already underway to ascertain whether or not the disparate needs of academia and the arts should split the Canada Council.

In 1964, Secretary of State Minister Maurice Lamontagne encouraged the Council to apportion this last batch of money over three years, for as Milligan points out, there was no guarantee of future financial aid, nor did the federal government "give any indication of the scale of operations that the government was prepared to support." ${ }^{152}$ Throughout this early period of acute uncertainty, the Canada Council had provided direct support to only select film related events, as follows: the Canadian Film Institute received a grant of $\$ 216,000$, for film acquisition and cataloguing (1958); la Cinémathèque Canadienne received $\$ 15,000$, to publish information on Canadian film (1965); la Coopération de Montréal received \$14,000, to produce four films (1965); and, le Conservatoire d'art cinématographique de Montréal received $\$ 20,000$, in support of the Montréal International Film Festival (1965). ${ }^{153}$ For the time being, Council seemed to stretch over the film community like a tripod, balancing its minimal support across that essential triangle so vital to mediated arts: production, exhibition and distribution.

As such, financial aid to the film community from the Canada Council aimed principally at an organizational (versus individual) level, with a clear bias for dissemination activities that favoured national (versus local) initiatives; awards for the plethora of centrally based organisations can be read, not as regional (Québec-

${ }^{151}$ Granatstein, p. 471.

152 Milligan, p. 72.

${ }^{153}$ Media Arts 1985: A Brief History of the Development of Media Arts Funding and the Media Arts Sector, (Ottawa: Canada Council, Spring 1985). 
Ontario), or local (Montréal-Ottawa), but rather as national in scope, given that they did "in all fairness promote the interests and serve the needs of the two main cultural groups of our country." ${ }^{154}$ Moreover, the cultivation and promotion of Canadian film culture through such distribution and exhibition initiatives reveals inaugural policy that sought to foster an awareness that would augment the potential for national discourse and subsequently raise the cultural collateral of Canadian film within the federal policy framework to which Council was now beholden. In that the Council thus fostered the promotion, study and enjoyment of culture, it was true to its mandate, and as it also honoured its founding spirit of nationalism, it neatly overlapped provincial-national/cultural-educational dichotomies. ${ }^{155}$ However, even without the overt promotion of film as an elite art form, Council continued to endorse high culture through its delimited support for artistic initiatives within "organizations that are likely to achieve some degree of national prominence and ... to create an audience." ${ }^{156}$ The local enculturation process was, for now, still being held at bay. In fact, as early as 1960 , policy debates within Council on the subject of direct funding for localized film production focused upon whether or not to provide support to individuals at all. The argument against funding the creation of such new work rested on the justification that the bulk of the proposals which came directly from filmmakers could find production support at the NFB, while broadcast journalists

\footnotetext{
${ }^{154}$ Lévesque, quoted in Granatstein, p. 469.

155 John Meisel and Jean Van Loon refer to "lively government involvement with culture ... [as] 'competitive federalism' ... [a] rather bizarre Canadian phenomenon [that] was triggered in the first instance by separatist tendencies in Quebec." Meisel and Van Loon, p. 281.

${ }^{156}$ Claude Bissell, quoted in Granatstein, p. 450.
} 
might themselves turn to the $\mathrm{CBC}$ to foster career development. ${ }^{157}$ Certainly, the Massey Report produced by the Royal Commission on the Arts, Letters and Sciences had reinforced that "the National Film Board should continue to produce films,", even suggesting that only the NFB had the resources necessary to sustain research and experimentation. It was becoming evident that if the Canada Council was to cultivate any independent media production activity, filmmakers would have to carve out a distinctive niche that would hold their work apart from client services already offered within pre-existing government sponsored institutions.

\section{Independent Feature Film Policy}

By the mid-1960s, university students had taken up cameras, creating a strong underground swell that expanded the character of the independent film sector with the increased production of feature-length films, both dramatic and documentary. Significant works were: Bitter Ash (Larry Kent, 1963); Winter Kept Us Warm (David Sector, 1965); and, Seul ou avec d'autres (Denys Arcand, Denis Héroux, Stéphane Venne, 1962). The NFB also began producing its first feature-length films, including: Pour la suite du monde (Pierre Perrault et Michel Brault, 1963); Drylanders (Don Haldene, 1963); Le chat dans le sac (Gilles Groulx, 1964); and Nobody Waved Goodbye (Don Owen, 1964). In fact, as the NFB became more and more involved in the production of feature film it also engaged with federal government policy development through Secretary of State offices, in order to address the augmenting

\footnotetext{
${ }^{157}$ Granatstein, p. 468.

${ }^{158}$ Massey Report, Ch. XIX, The National Film Board, p. 311.
} 
needs of the feature film community at large. Notably, independent commercial filmmakers, such as Budge Crawley of Ottawa (Amenita Petilensis, 1964) were still fighting against what they continued to perceive as a government monopoly over film production and distribution in Canada, that is, publicly sponsored work produced through the CBC and the NFB that had historically denied the private sector both a livelihood and a place on the cultural mantelpiece, essentially through dwarfed audience potential.

In 1958, the Industry Development Committee of the Association of Motion Picture Producers and Laboratories of Canada had already submitted a draft brief to the Diefenbaker government, arguing that "a stronger commercial film industry has a useful contribution to make to our national struggle ... it is now an objective of our Association to increase our participation in this work." 159 Then, during the ensuing reign of the Liberals under Prime Minister Lester B. Pearson (1963-68), policy activity included the formation of The Interdepartmental Committee on the Possible Development of Feature Film Production in Canada, chaired by Guy Roberge, Government Film Commissioner at the NFB. Guy L. Côté, then president of the Association professionnelle des cinéastes, wrote several reports for the Committee, in addition to producing his own films; Côté was also one of four people who ran the Canada Council funded Montréal International Film Festival. ${ }^{160}$

${ }^{159}$ Dorland, p. 59. Other cornerstone reports of this era include The Firestone Study, Film Distribution, Practices Problems and Prospects (1964) and of course, The Standing Committee on Broadcasting, Film and Assistance to the Arts (1966), with First Chairman, Gerard Pelletier. For a full exploration of such issues, consult Dorland, Chapter Four: Reconfiguring the Public Sphere, pp. 58-84.

${ }^{160}$ The Canada Council was also involved in the feature film arena through its support for building and distributing film collections at the Canadian Film Institute (CFI), as well as through the financing of publications on Canadian film, also at the CFI and at la Cinémathèque Canadienne. 
The direct result of keen and renewed interest in the role of feature film and broadcasting policy on the part of the Canadian federal government produced, however, what Michael Dorland refers to as, "the displacement of what was initially a discourse about cultural development by one of industrial development."161 According to Dorland, on the $25^{\text {th }}$ anniversary of the NFB (1964), Secretary of State Minister Lamontagne "repeated much of the substance of the 1956 speech he had written for then Prime Minister Louis St-Laurent ... a rationale for the policy of state intervention in the domain of cultural production to redress the disequilibrium between Canada's economic growth and the poverty and isolation of Canadian cultural life." 162

Feature film policy activity of this era finally culminated with the Canadian Film Development Corporation Act, passed in February of 1967, "to foster and promote the development of a feature film industry." 163 The Canadian Film Development Corporation (CFDC) was to support commercial film within the preestablished international industrial framework, thus pitching the Canadian featurelength film into a hierarchical and materialistic governance strategy. Dorland bemoaned the nature of future independent film production in Canada: "Ironically ... the filmmakers themselves had all the while clamoured for the establishment of a traditional film industry that would only reinstitute the tyranny of the conventional script." 164 Indeed, while feature filmmaking in Canada was going down the corporate

${ }^{161}$ Dorland, p. 111.

162 Ibid.

${ }^{163}$ Dorland, p. 136.

${ }^{164}$ Dorland, p. 113. Here Dorland is referencing the fate of an emerging film practice, that of direct cinema. 
road, ${ }^{165}$ thus cleaving this production practice from any prospective niche that the

Canada Council might fund, Council was again left to reassess its role within the film production community.

\section{Challenge for Change, Shorts and Television}

The White Paper on Broadcasting, issued as a result of The Standing

Committee on Broadcasting, Film and Assistance to the Arts (1966), stated the purpose of Canadian broadcasting policy as follows: “The determination to develop and maintain a national system of radio and television broadcasting in Canada is an essential part of the continuing resolve for Canadian identity and Canadian unity."166 Similarly, the Broadcasting Act of 1968 also linked cultural policy to national unity. ${ }^{167}$ Meanwhile, the Canadian government was itself struggling to find an appropriate means to support indigenous, short-form, media-based practices that could feed Canadian content to the public through the increasingly voracious platform that television presented.

The Challenge for Change program that ensued was created through subsidy from seven different federal departments in order to reinforce "the image of Canada

${ }^{165}$ This is a reference to an independently funded, regionally produced, feature-length fiction film, Goin' Down the Road (Don Shebib, 1970). Although a few independent filmmakers would persist to work beyond government funding in the feature-length format, while the NFB also continued to sporadically fund this length of work, most feature-length filmmakers opted for a more commercial route and began to finance their work through the CFDC.

${ }^{166}$ Marc Raboy, Missed Opportunities: The Story of Canada's Broadcasting Policy (Montréal: McGill-Queens University Press, 1990), p. 171.

${ }^{167}$ According to Forcier and Schafer, p. 23, the 'Artist's Brief,' as submitted to the Turgenon Committee, had also made this direct link back in 1944. 
as an advanced democratic nation," 168 and it was established within the administrative structure of the NFB. The program was, after all, intended to "encourage dialogue and promote social change," ${ }^{169}$ and the NFB, as an organization that had always served its government through educational purpose, now sought to pitch this work at the television market, as part of the struggle to soothe Canadians into one smooth nation. So, while the Massey Report from the Royal Commission on Arts, Letters and Sciences had taken the high road when it advised against a National Film Board of Canada that would "become simply or principally a supplier of films for television," ${ }^{170}$ Challenge for Change reopened debates over the role that regional film and video production might have in relation to cable television.

While independent film and video producers found limited release through cable television, community broadcasting emerged "with the concurrent development of relatively inexpensive light-weight video production technology and local cable distribution systems with unused channel capacity ... ideally suited to decentralizing and deprofessionalizing media production, while increasing access and public participation."171 Indeed, Marc Raboy claims that the Special Senate Committee on Mass Media, established in 1969, "brought together for the first time all the diverse experiences then taking place in both the traditional, or mainstream, media, and the new, or alternative, media in Canada... the technological threshold of the late 1960s was recognized as offering a potentially novel approach towards the radical social and

${ }^{168}$ Janine Marchessault, "Amateur Video and Challenge for Change," in Mirror Machine: Video and Identity, Janine Marchessault, ed. (Toronto: YYZ Books, 1995), p. 13.

${ }^{169}$ Marchessault, p. 13.

${ }^{170}$ Dorland, p. 40.

${ }^{171}$ Raboy, p. 202. 
political demands of the period." ${ }^{172}$ As Janine Marschessault further states, the aims of the Challenge for Change project were very simple: "Give the disenfranchised and marginal communities of Canada a voice by giving them access to the media (film and later super 8, video and cable television). ${ }^{, 173}$ According to Marchessault, video had became a tool within a "highly instrumental view of cultural development... [that] reflected the Liberal's two-fold policy to democratize and regionalize culture, a strategy largely aimed at integrating the margins into the mainstream of Canadian life." 174 Interestingly, this new policy would also provide an impetus for the cultivation of a niche for community-based media art production within the Canada Council.

\section{The Stabilization of the Canada Council}

As the government of Canada continued to address national film and broadcasting policy through Secretary of State, the Canada Council hosted several public seminars. First, Seminar ' 65 took place in Saint Adèle, Québec; it was cosponsored by the federally supported Centennial Commission, which had been established by Ottawa to mark the upcoming centenary of Canada's confederation (1967). The conference itself boasted attendance of almost 150 artists; Secretary of State Minister Lamontagne gave the opening address, while national representation also included officials from government agencies across the country. Peter Dwyer,

\footnotetext{
${ }^{172}$ Raboy, p. 201.

${ }^{173}$ Marchessault, p. 13.

${ }^{174}$ Marchessault, p. 14. She acknowledges D.B. Jones, Movies and Memoranda: The National Film Board of Canada, Canadian Film Institute, Ottawa, 1981, pp. 171-172.
} 
then Associate Director of the Canada Council, addressed the artists at Saint-Adèle reassuringly when he proclaimed that, "We have tried to make the Council's actions responsive to your advice, so that they were (whenever it seemed possible) reflecting a consensus of the artistic community." "175 According to André Fortier, who would become the Director of the Canada Council in 1971, "Participants at Seminar 65 recommended that the Canada Council continue to be the principal agency for distributing funds from the government or from other sources of support for the arts." 176

The Canada Council followed up on the success of Saint-Adèle one year later, when Seminar 66 was held in Scarborough, Ontario. Under the theme, The Unity of Visual Arts in Society, participation at the conference was limited to one hundred, while those participants made fifty recommendations "respecting art education, information and research, taxation, the environment and a variety of other topics of great interest to artists." forefront of this part of the arts community's future hopes... [and] even asked to organize a meeting of provincial education ministers, devoted to the teaching of the visual arts." ${ }^{178}$ It would appear as though, on the surface, the Council was indeed successfully balancing the needs of the arts community and those of the federal government in its dual role as both private and public servant, although to date, Council remained without clear policy on how, or whether, it would expand to

\footnotetext{
${ }^{175}$ Peter Dwyer, quoted in Milligan, p. 88.

${ }^{176}$ Fortier and Schafer, pp. 18-19.

${ }^{177}$ Fortier and Schafer, p. 19.

${ }^{178}$ Ibid.
} 
address localized independent film or video production, beyond the minimal support it had provided thus far through the established Visual Arts Sector.

Judy Lamarch was the Secretary of State Minister when Council, directly on the heels of Seminar 66, submitted a successful three-year budget plan to Cabinet, who approved the request for $\$ 17$ million in the fall. Finally, "annual appropriations were introduced and became the steady financial support for the Council in 196768." $" 179$ Fortier and Schafer state: "This event marked the beginning of a new relationship between the government and the Canada Council, which appreciably affected the evolution of federal arts policies." ${ }^{180}$ As Milligan claims, "In 1968, an understanding was reached between the Council and the Treasury Board which seemed to reconcile the new financial relationship with the established autonomy of the Council in the conduct of its activities. It was agreed that the Council would in future submit details of its program plans to substantiate its requests for annual appropriations - like any department or agency of the government... [while Council] retained complete freedom, within each sector of its program, to spend its money as it wished." 181 This unique construction of the Canada Council as a federal agency meant that Council was "in some ways a public agency and, in others, a private foundation ... a distinctively Canadian hybrid."182 Indeed, as the Council's financial needs increased, so too would its exponential need for the full support of its artsbased constituency.

\footnotetext{
${ }^{179}$ Fortier and Schafer, p. 19.

${ }^{180}$ Ibid.

${ }^{181}$ Milligan, pp. 73-74.

182 Granatstein, p. 445.
} 


\section{Awarding the Media Arts at Canada Council}

The Canada Council began to build its ties within the arts community more

formally, initially through the establishment of the Arts Advisory Panel, in 1965.

Soon thereafter, the Canada Council was to also award its first media arts

organization with the single, largest amount it had issued to date. In 1967, a grant of

$\$ 40,000$ went to the Vancouver-based artist-run centre, Intermedia. ${ }^{183}$ Sara Diamond writes:

The Canada Council had rallied to support Intermedia, an organization founded by key figures in the Vancouver art world such as Jack Shadbolt, Roy Kiyooka, Michael Morris, Iain Baxter and Alvin Balkind ... Initially, Intermedia was celebratory, with events and exhibitions that explored analogue and digital technology as well as multidisciplinary art practice. The initial rhetoric of Intermedia implied a positivist and uncritical rush towards new technologies as a solution to a Canadian economic and social identity crisis. Its mandate was to bring together the potential of art, science and industry... Vancouverites hailed the moment as a 'new alchemy,' championing the artistic possibilities inherent in 'new electronic technologies,' the 'fusion of art and technology.

Thus, within the spirit of rising counter-culture movements, newly inclusive federal policy developments had effectively made some room for the production of media arts; it was the combination of new financial arrangements and the advent of video technology that provided the first concrete signs of evolutionary support from within the Canada Council for an increasingly diverse spectrum of media arts practitioners.

\footnotetext{
${ }^{183}$ The Canada Council for the Arts, "Appendix 1: Visual Arts Chronology 1958-1993: A Brief History of Visual Arts Funding," in Artists' Centres: A Twenty Year Perspective, 1972-1992 (Ottawa: The Canada Council, September, 1993).

${ }^{184}$ Sara Diamond, "Turn that Camera Inside Out: Some Thoughts on Synaesthesia," in Making Video 'In', p. 68.
} 
In fact, both video and experimental film artists had emerged from the visual arts movements of the 1960 s, including the raft of independent filmmakers who participated in Intermedia (David Rimmer, Al Razutis, Dallas Selman, Taki Bluesinger and Gerry Gilbert). ${ }^{185}$ Canadian experimental film was also reaching new international audiences at this time, as evidenced by Wavelength (Michael Snow, 1967), which took top prize at the Knok ke-le-Zoute Festival in Belgium. Independent media artists were also actively criss-crossing the country creating a "communications environment,' according to Michael Goldberg. Such activity led to the formation of la Société Franco-Manitobaine, which emerged in Winnipeg in 1970. Intermedia also lent its support to the establishment of International Video Exchange Directory/Bottin Vidéo international, "to encourage worldwide exchange of non-commercial videotapes, ${ }^{186}$ plus a 1973 conference, Matrix, which drew over 160 participants from Canada, the U.S., Europe and Japan. ${ }^{187}$ Ultimately, as Goldberg acknowledges, "Intermedia became so large, it eventually split into several more specialized groups, including Intermedia Press, Metro Media, the Video Inn, and the Western Front."188

Indeed, the Canada-wide community of media arts practitioners now stretched across traditional arts disciplines, as media art came to include cinema, photography, video, holography, performance, installation and audio art. By 1972, the Canada Council was funding several centres that incorporated media arts practices, and while

\footnotetext{
${ }^{185}$ Michael Goldberg, "Before the Generation Loss: the Early Years of Video", in Making Video 'In', p. 35.

${ }^{186}$ Seven updates of the directory were to follow.

${ }^{187}$ The name Matrix was chosen "to suggest a network that is decentralized and flexible, like telephone exchange, ham radio or geodesic domes - if some of the lines are cut, the system can still function as a whole." Goldberg, p. 36.

${ }^{188}$ Goldberg, p. 34.
} 
the Visual Arts Sector had established a Film Program in $1969,{ }^{189}$ the flurry of production activity also generated a Video Program in 1975, primarily to accommodate this growth in cross-disciplinary arts practices. Council increased funding to centres that dealt uniquely with media arts, including: Independent Filmmakers Co-op of Montreal (the first film production co-op); the Canadian Filmmakers Distribution Centre (Toronto); and the Pacific Cinémathèque (an exhibition oriented co-operative in Vancouver). The first operational grants for video production centres went to Vidéographe (Montréal) and Video Ring (Toronto).

And as the Canada Council began to fund various explorational media art practices through the Visual Arts Section, it also started to tie this support to the creation of individual works, moving slowly toward the full embrace of its mandate, which had always included 'the production of works in the arts.' In 1972, Council held the first juried Film Production grant competitions, awarding the Atlantic Filmmakers Co-op (Halifax), the Toronto Filmmakers Co-op, the Association Coopérative de productions audiovisuelles (Montréal), Satellite Video Exchange Society (Vancouver), Visus (Toronto) and Metro Media (Vancouver). Significantly, Michael Goldberg and Trish Harman received the first video production grants awarded to individuals ${ }^{190}$ these were, in fact, discretionary grants allocated by

${ }^{189}$ A chronology of significant events on the Media Arts page of the Canada Council website records, for 1969: "Cinema and Photography introduced as a distinct discipline." Downloaded in the summer of 2003, www.canadacouncil.ca

${ }^{190}$ These statistics were compiled from various sections within the report, Artists' Centres: A Twenty Year Perspective, 1972-1992, introduced by Edythe Goodridge, Head of the Visual Arts Section. "Attachment B: Media-Based Artists' Centres" lists funding statistics specific to media arts culture, while "Appendix 1: Visual Arts Chronology 1958-1993: A Brief History of Visual Arts Funding" records galleries and inter-disciplinary artist-run centres that were listed as Visual Arts activities. It should be noted that these 'parallel' art galleries, such as the Clouds 'n Waters Gallery in 
Council Officers in advance of the first juried Video Production grant competition, which took place in 1975.

\section{Federal Cultural Policy and Funding Parameters for the Media Arts}

While the individual artist-run centres that began to arise across Canada have each their own story to tell in the struggle to secure ongoing operational funding, they all invoke Clive Robertson, who astutely affirms that "the social and cultural interventions and ambitions of artist-run centres are re-designated by funding agency policy, and by artists themselves, to fit a narrower or more specific ... discourse." ${ }^{191}$ In 1971, for example, the Canadian Horizons Program was launched within the Canada Council as an extension of the New Horizons program, itself created by the federal government through Health and Welfare. Canadian Horizons provided money for some film and audio-visual projects, one of which indeed had established Video Inn in Vancouver. According to Goldberg, Horizons "had outlived its usefulness for funding small, local history projects, ${ }^{192}$ and during an informal meeting with a government official, Robert Kennedy, "a rambling chat behind Parliament Hill ... I requested that ... room be made for social experimentation by artists." ${ }^{193}$ Video Inn received $\$ 20,000$ to begin operations from the soon to be extinct New Horizons Program.

Calgary (est. 1974), chose to showcase new mediated art works such as were emerging from the realm of highly cross-disciplinary artist-run culture.

${ }^{191}$ Robertson, p.1.

192 Goldberg, p. 36.

${ }^{193}$ Ibid. 
Then, two other programs were established in place of the New Horizons Program, ostensibly to create jobs for the unemployed: Opportunities for Youth; and, the Local Initiatives Program. Fortier and Schafer claim that “... many professional arts organizations, currently subsidized by the Canada Council or provincial or municipal arts programs, got started through initial assistance granted under both programs... [which] helped attain the objectives of democratization and decentralization contained in the federal cultural policy." 194 Yet, the Canada Council was itself reluctant to accept funding through federal initiatives such as these, for the parameters of such regulated government programs did not fit well into the arm's length relationship they struggled to affirm.

Indeed, Robertson problematizes such relationships as the "nudging of individuals and collectives into more formal entities by funding agencies." ${ }^{\prime 95}$ It must be acknowledged that within artist-run culture at large "the project of artists' selfgovernance is itself continuously amended by changing funding relationships ... artist-run is actually better employed as a description of investments ... the construction of working relationships."196 Therefore, even as the activism of a grassroots arts movement entwined with federal policy in order to build the long-desired, networked community of artist-run centres, such funding policy would increasingly further delimit film and arts related activity within both the Canadian cultural sphere at large and the microcosm of the Canada Council.

${ }^{194}$ Fortier and Schafer, p. 29 . The federal cultural policy to which they refer is generally known as 'the Pelletier policy,' actually a series of cultural policies introduced when Gérard Pelletier was Secretary of State for the Liberal government, led by Prime Minister Pierre Elliot Trudeau.

${ }^{195}$ Robertson, p. 18.

${ }^{196}$ Robertson, p. 6. 
On July 4, 1972, Secretary of State Minister Gérard Pelletier gave a speech in Montreal; he outlined the first phase of a national film policy that would facilitate access for creators to professional training, to the means of production, to an expanded national film culture, and to markets. Included in the speech was a much more clearly defined role for the Canada Council, who would "continue to provide substantial amounts of aid to bodies concerned with the conservation and spread of film ... [and] become fully responsible for subsidizing experimental film."197 The federal government had thus finally clarified a mandate for the contribution that the Canada Council was to make to Canadian film culture: in recognition of its more recent support for experimentation within media arts practices, Council was to take full responsibility for experimental media productions. And, in acknowledgement of the work it had been doing on behalf of the distribution and exhibition of film, Council was also to continue with media arts related dissemination activity.

But what exactly was involved in the federal mandate that now held Council responsible for the 'conservation' of film? Was this policy shift meant to direct the Canada Council toward providing specific funding to arts organizations for the maintenance of film collections, including those artist-run centres to which Council already provided financial support for the ongoing distribution and exhibition of independent film? This would then suggest that the Canadian Film Institute, the Cinémathèque Québécoise, ${ }^{198}$ the Canadian Filmmakers Distribution Co-operative,

${ }^{197}$ Gérard Pelletier, "Canada's Film Policy: The First Phase," Cinema Canada, Second Edition, no. 3, (July/August 1972), p. 7.

${ }^{198} \mathrm{La}$ Cinémathèque Canadienne became la Cinémathèque Québecoise in 1971. 
and the Pacific Cinémathèque would all become eligible for grants for the upkeep of each respective collection, including the physical and intellectual control and other detailed conservation prerequisites inherent to such audiovisual preservation.

However, while the Canada Council's budget shrank by $10 \%$ over the next six years, ${ }^{199}$ the film and video community continued to grow. It suddenly seemed increasingly unlikely that the Council itself could do more than minister to the immediate needs of a community of artists that had become increasingly vocal with demands for support of the envisioned national network of artist-run centres. So, as dissemination activities throughout the artists' network grew, the Council and the community continued to adequately meet the Pelletier objective that insisted that Council encourage the spread of film. And perhaps, given that Council already provided direct support to the CFI, which had indeed established the Canadian Film Archive in 1963, it might, at a stretch, be seen as trying to meet the mandate to conserve. But was this effort sufficient to provide for the conservation of independent film culture?

As both the film and the video community diversified, demands from within artist-run culture remained steadfastly focused on solidifying what began as an unwieldy network. In 1976, after the fourth annual Winnipeg Film Symposium, Cinema Canada reported the following:

In a denouement to the proceedings, two meetings were held on the last day of the Symposium, when no panels had been scheduled. Both concentrated on the co-op future, whether for those already in existence or those about to be formed.

\footnotetext{
${ }^{199}$ Fortier and Schafer, p. 35.
} 
The first discussion concerned establishing a national union of co-ops. It was very practical, with political action, exchange of newsletters, using the local media to promote Canadian film; and tentative agreement of a union. The gathering also served as a forum for communication between regions; discussions centred on availability of films to the public within and from without the various regions. The concept of the co-op was debated, and the result was a great deal of common thinking along all the regions. Politicization levels of young and older filmmakers in each region was outlined. Present were the Pacific Film Co-op, the Winnipeg Film Group, the Toronto Filmmakers' Co-op, the Atlantic Film Co-op, and interested individuals.

Later in the afternoon, representatives of the above groups met with Canada Council Film Officer Françoyse Picard...

During the next three years, said Picard, the Council would like to phase out direct grants to co-ops. Perhaps other bodies, such as provincial Arts councils, could contribute instead. Instead of direct funding for operating expenses, each co-op would apply to the Council for a grant for a particular film, under any suitable Council program. ${ }^{200}$

Indeed, provincial parties had not stopped rallying for greater control over cultural funding; in 1976, Jean-Paul L'Allier, Quebec Minister of Cultural Affairs, spoke to what is known as 'the Green Paper,' Pour l'évolution de la politique culturelle. Making a case for provincial jurisdiction over culture, L'Allier wrote simply that, although "enticing and ambiguous, federal action does not sort things out... [further] Quebec claimed a pre-eminent role for the development of arts and culture... [and] wished, in the long run, to repatriate federal funds allocated to the arts and culture. ${ }^{201}$ By 1978, Fernand Dumont and Guy Rocher had also filed, A Cultural Development Policy for Quebec, the 'new white paper, ${ }^{202}$ which proposed the

${ }^{200}$ Cinema Canada, Third Edition, no. 26, (March 1976), p. 7.

${ }^{201}$ Fortier and Schafer, p. 37.

${ }^{202}$ The original 'White Paper' was written by Quebec Cultural Affairs Minister, Pierre Laporte (The White Paper, Nov. 1965) but it was never published or tabled in the National Assembly because the Lesage government was defeated. However, Fortier and Schafer, claim that "this 
development of the Institut Québecois de la recherche sur la culture and La Societé de développement culturelle.

Pelletier had also inaugurated the Assembly of Arts Administrators, which was created to allow both federal and provincial senior civil servants to meet twice a year. This was the precursor to the Federation of Canadian Municipalities, which in 1976 indeed developed a three tiered funding formula to administer to the growing arts community, capping the municipal share for arts funding at $\$ 1$ per capita and the provincial responsibility at $\$ 2$, to match the $\$ 3$ contribution from the federal government. Overall, the artist-run movement might have been considered to be in better shape, relatively speaking, as funding levels appeared to increase in provincial and municipal environments, while those at Council shrank. However, it must always be remembered that very few cities, provinces or territories invested in independent 'experimental' film or media art production in the mid-70s.

\section{The Video Art Community}

Further to the developing video arts community, in 1977 the Canada Council hosted a critical gathering of video artists, now known as the Stanley House Colloquium, where participants discussed the possibility of founding an Electronic Media Programme at the Canada Council. In March 1977, the Electronic Media Programme: Policy Report with Recommendations (subsequently referred to as the 
Electronic Media Report), was filed with the Council as a result of these meetings. ${ }^{203}$

The opening paragraph of the report began:

The evolution of electronic media in Canada has been overwhelmingly influenced by commercial ends. There are possibilities and directions inherent in radio and television which cannot be explored within the context of these mass-media, since audienceratings narrowly limit the parameters and rate of their evolution. They are designed to deliver audiences to commercial sponsors, not creators to an audience. With the recent development and accessibility of small-format (low-gauge) equipment, a much wider scope has been brought to these media than was thought possible in the past. ${ }^{204}$

Directly addressing developments within the media arts community, the Electronic Media Report goes on to state, "the fact remains that 'community media', as it has come to be called, had developed an 'alternative' stance. With no access to commercial and national airwaves, artists and producers have developed methods of operation and distribution-structures intrinsic to their own aspirations. Artists and community-groups have evolved together a strong, interactive working relationship."205

The first heading beyond the Introduction to the Electronic Media Report reads: "Expansion of the Video Programme to Include Audio and Other Electronic Media," suggesting not an amalgamation of the audiovisual programmes already existing within the Visual Arts Sector, (Film, Photography, Holography and Video) but rather, the establishment of a new, technology-specific programme that would

${ }^{203}$ Found at the Canada Council for the Arts, Documentation and Research Library, the document is date stamped March 1977 within a circular insignia naming The Canada Council/Le Conseil des arts du Canada; there is a penned title written on the cover page: Electronic Media Programme: Policy Report with Recommendations.

${ }^{204}$ Electronic Media Programme: Policy Report with Recommendations, p. 1.

${ }^{205}$ Ibid. 
embrace the essence of Challenge for Change - decentralization and democratization, in this case, through community narrow-casting. To that end, the Electronic Media Report recommended the allocation of $\$ 500,000$ over three to five years, which was equivalent to the support Council already provided to the Video Program. Indeed, by raising issues around community radio broadcasting and the CRTC, the report advocated that, instead of accessing the Canada Council's Explorations Programme, "a variety of exciting and dedicated groups not eligible under other Council programmes ... might be better integrated into the Video Programme." ${ }^{206}$ Making a case for a more expansive programme at Council that would directly address the use of electronic technology by artists, the Electronic Media Report acknowledged the breadth of scope within 'community-media', citing "a wide range of artistic disciplines and styles, as well as a diversity of points of view."207

The Electronic Media Report concluded with separate documents written by artists and/or arts administrators from within artist-run culture itself. All encouraged increased support from the Canada Council for video and audio production, exhibition, and specifically, distribution. Paul Wong of Satellite Video Exchange, submitted Concepts and Potentials for Video Exchange, Andy Harvey of Video Inn, Community Video Library, Bob Arn, Distribution and the Artist-Video Producer, and Peggy Gale of Art Metropole, Distribution in a Wider Context. Gale summarized the overall focus with the following: "Small format video tape has many uses, and its circulation of distribution must be tailored accordingly. Those who are using video as

\footnotetext{
${ }^{206}$ Electronic Media Programme, p. 8.

${ }^{207}$ Electronic Media Programme, pp. 1-2.
} 
a means to make art (as a painter would use canvas, paint and brushes) want different outlets and viewing circumstances than does someone using it as a communication tool for teaching, for documentation, or for social change."208 Gale's report also contextualized the approach for artistic production from within artist-run culture, as follows: "Artist's use of video and audio does not lie in a finite, closed sphere within community media. It is an intrinsic part of community use. It is also an attempt to reach a community of people outside the present art context (e.g. public museums)."209

And finally, while overall the Electronic Media Report addressed community networking and distribution as most important, it also reaffirmed the paramount importance of production, urging the Canada Council throughout to adapt its equipment policy to allow access to equipment for individuals, not only organizations:

In grants to organizations, operating costs will have priority. Grants for equipment will only be considered where an organization has adequate funds for its operations. ... for equipment worth more than $\$ 1,000$ [organizations] must be incorporated as non-profit companies... the maximum value of an equipment grant to any one organization in any one year will be $\$ 20,000 \ldots{ }^{210}$

The introduction of Equipment Purchase Grants at the Canada Council in 1976-77 was in direct response to such requests from media artists who desperately needed

${ }^{208}$ Peggy Gale, "Distribution in a Wider Context," Electronic Media Programme: Policy Report with Recommendations, p. 48.

${ }^{209}$ Gale, Electronic Media Programme, p. 4.

${ }^{210}$ Memorandum to Council - Equipment Policy: Arts and Explorations, contained within the Electronic Media Programme, p. 15. This section is dated 24.3.75 and initialled 'T.P.'. 
increased access to the means by which to produce work. ${ }^{211}$

Critically, throughout the push for an expanded arena for media art, there was only the slightest indication that the community was also reflecting upon the conservation aspect ensconced within the Pelletier directive. Gale wrote most directly on the subject: "Art Metropole was conceived without a single model, but rather with elements of an independent filmmaker's distribution centre, cinematheque, commercial art gallery, and library/archive/information centre. We deal with the tapes as original works of art." ${ }^{212}$ Andy Harvey wrote about "the cataloguing system [at Video Inn]... and the functioning of such libraries in general,"213 and Paul Wong addressed the need "to expose videotapes of good technical, visual and content quality."214 While these are overall aspects of the care of audiovisual records, and also reminiscent of early preservation practices undertaken on behalf of circulating film collections, they do not constitute a holistic approach to the conservation, preservation or archival care of audiovisual materials.

Clearly, as the young and vibrant media arts community struggled to assert itself, the critical issue of how it would indeed conserve its work was not immediately prioritized by artists. Instead, the community pushed on with the evolution toward a

${ }^{211}$ Canada Council for the Arts, Trends in Support to the Arts - Technical Tables, $10^{\text {th }}$ Edition, (Ottawa: Canada Council for the Arts, Feb. 1990), p. vii.

${ }^{212}$ Gale, p. 48. Emphasis mine. Art Metropole would receive a grant of $\$ 11,690$ from the Visual Arts Sector of Council in 1979, "for the operation of an archive." Canada Council for the Arts, Artists' Centres: A Twenty Year Perspective, 1972 - 1992 (Ottawa: September, 1993), p. 7.

${ }^{213}$ Andy Harvey, "Community Video Library," Electronic Media Programme: Policy Report with Recommendations, p. 26.

${ }^{214}$ Paul Wong, "Concepts and Potentials for Video Exchange," Electronic Media Programme: Policy Report with Recommendations, p. 28. This paper also discusses copyright issues and remuneration for artists. 
supported, networked community, a goal the Canadian arts community had held onto since the 'Artists' Brief' of 1944. The introduction at the Canada Council of the Visiting Artists Program in 1977-78 further strengthened the coveted network, as it enabled artists to travel and meet more freely, beyond sporadic jury duty at Council. Bearing in mind the many hats worn by those within artist-run centres, artists-asadministrators were also able to strategize for their future with greater ease.

\section{Founding a National Alliance of Media Artists}

Finally, at the Colloquium on Independent Film, November 1979, in Mont St. Marie, Québec, the media arts community formally broached the establishment of the Independent Film Alliance du Cinéma Indépendent (IFACI). ${ }^{215}$ After group consultations in February 1980 during Canadian Images, a festival in Peterborough, Ontario, it was agreed that "regional representatives from various independent film co-operatives across Canada will meet in Winnipeg, May 30 to June 1, to discuss establishing a National Association of Independent Film Producers and Distributors.",216 Three months later, "the Winnipeg meetings ended with agreement by delegates present to loosely affiliate to continue discussions leading to the formation in due course of a formal alliance. ${ }^{217}$ And six months after that, a "Proposed Structure for Affiliation" was presented at the Yorkton Independent Film Conference in November 1980: it was based on "a statement presented to the

${ }^{215}$ Press Release issued by the Alliance, dated December 1979. This document, along with those to follow, was found in the archival records of the Independent Media Arts Alliance (IMAA), Montreal, July 2004. The author was free to make photocopies (documented by written permission).

${ }^{216}$ Winnipeg Film Group, News Release, May 30, 1980.

${ }^{217}$ Structure Committee Report, Yorkton Independent Film Conference, Nov. 1980, p. 1. 
Winnipeg meeting by Atlantic area film groups, ${ }^{, 218}$ made up of the Atlantic Film Coop (Halifax, 1974), NIFCO (St. John's Newfoundland, 1975) and the New Brunswick Filmmaker's Co-operative (Fredericton, 1979). This working paper, which proposed the constitutional structure within a document entitled, "How and Why our Co-op's Started," became the blue print for the bylaws of the IFACI, whose Head Office was to first be in Winnipeg, Manitoba. ${ }^{219}$

The official by-laws of the IFACI are dated March 20, 1981, and the mandate reads as follows:

The Independent Film Alliance du Cinéma Indépendent is a non-profit incorporation whose purpose is to further the production, exhibition, distribution, and preservation of independent film in Canada through action on behalf of its members. ${ }^{220}$ At present, IFACI represents approximately five hundred filmmakers and associates through twelve groups. Members: Canadian Filmmakers' Distribution Centre (Vancouver), Newfoundland Independent Filmmakers' Co-operative, Association Acadienne du Cinéma Inc., Nunatsiamkmiut, Calgary Society of Independent Filmmakers, Ciné-tracts, Liaison of Independent Filmmakers in Toronto, The Funnel Experimental Film Theatre, Cineworks, Winnipeg Film Group, Edmonton Filmmakers' Studio, and Atlantic Filmmaker's Co-operative. ${ }^{221}$

Notably, video co-operatives were not among the initial members of the IFACI, indeed the very title of the organization suggested a film focus. In fact, an invitational form letter for membership went out in the year between official inauguration and the first formal AGM, which addressed members with 'Dear Film Group.' By 1981,

\footnotetext{
${ }^{218}$ Ibid.

${ }^{219}$ Atlantic Region, "Meeting to Discuss a National Association of Filmmakers," n.d.

${ }^{220}$ Emphasis mine.

${ }^{221}$ The By-laws consist of a nine page, legal sized document and detail the following procedures: Conditions of Membership; Head Office; Board of Directors; Indemnities to Directors and Others; Powers of Directors; Officers; Duties of Officers; Execution of Documents, Meetings; Minutes
} 
however, position papers were already being presented to the AGM of the IFACI on behalf of both film and video communities. ${ }^{222}$ Most importantly, however, is the fact that the IFACI immediately recognized preservation as an integral part of their work, which is likely due to concerns from those member-groups responsible for the maintenance, distribution and/or exhibition of increasingly large bodies of work, which will explored in more detail in Chapter Three.

\section{Establishing the Media Arts Sector within the Canada Council}

It was not long after the formation of the Independent Film Alliance du Cinéma that the organization affirmed that 'For a National Organization, there is strength in numbers." 223 Indeed, the IFACI would henceforth become an integral part of the reciprocal support mechanism that both the Canada Council and the independent media arts community of artist-run-centres needed in order to finally establish the Media Arts Sector within the Canada Council.

In February 1980, the Canada Council released Policy Options for the '80's, within which it fought to justify the continued need for a national funding body for the arts. Within the document, Council claimed its support for the following: national standards of excellence; the mobility of artists beyond provincial boundaries; the equalization of funding to level opportunity for artists and audiences; funding to

of Board of Directors and Executive Committees; Voting Members; Financial Year; Amendment of By-laws; Auditors; Books and Records; Rules and Regulations; and, Interpretation.

${ }^{222}$ For example, Funnel, a Toronto-based artist-run centre, presented the position paper "Film and Video Censorship," at the IFACI AGM in Ottawa, December 1981. Video-based artist-run centres would soon begin joining the Alliance.

${ }^{223}$ Minutes: Alliance Steering Committee Meeting, held at the Canadian Images Film Festival, March 9, 1981. 
national service organizations and national cultural events; and, international exposure through foreign exchange. ${ }^{224}$ The Council also summarized its position on federal-provincial responsibility as follows: "While the provincial governments should be encouraged to assume a larger share of responsibility for funding the arts, there remains an essential and a growing role for federal agencies such as the Council. ... neither level of government should be subordinate to the other, nor funded by the other. While there should be as much communication and consultation as possible between the different levels of government, each should be fully responsible for providing funding in the light of its own interests and policies." 225 The report also announced:

The Council's forecast for 1980-81, based on the general policy of restraint in government expenditures, foresees a further decline in the real value of the council's support to the arts... In constant dollars, the value of Council support to the arts has not materially increased since 1976. In 1979-80, for the first time, the total number of dollars available for arts grants will be the same as in the preceding year. The role which the Council plays in relation to the development of the arts in Canada is profoundly affected by this change in its financial situation. The emphasis has necessarily shifted from growth and diversification to consolidation and survival. ${ }^{226}$

However, by this time, the Council was also releasing much larger amounts of money than ever to film and video artists and organizations, in spite of the serious recession. In a press release dated April 30, 1980, grants were awarded to groups in the areas of distribution, production and exhibition, as follows: (11) film

\footnotetext{
${ }^{224}$ Canada Council, Policy Options for the '80's, (Ottawa: Canada Council, February, 1980).

${ }^{225}$ Canada Council, Policy Options for the ' 80 's, p. 15.

${ }^{226}$ Canada Council, Policy Options for the '80's, p. 18.
} 
organizations; ${ }^{227}$ (7) video organizations; ${ }^{228}$ (3) film festivals. ${ }^{229}$ Plus, (4) video organizations received project funding, ${ }^{230}(10)$ film artists received production funding, ${ }^{231}$ and (6) video artists also received production grants. Tellingly, the 1980 Report, Policy Options for the ' 80 's, went on to say that "One of the Council's strongest assets has been its ability to respond to new forms of artistic activity....It would be regrettable for the artistic life of the country if the Council, because of financial restraint, were to lose its ability to encourage new forms of expression. Yet in a period of declining Council budgets it would be irresponsible to launch new programs, however valuable or imaginative, since they would absorb the funds which are required to maintain existing excellence."232

Finally, in 1983, the Media Arts Sector was created as a separate and distinct unit within the Canada Council, which effectively knit together the various independent artistic communities that embraced mediated technologies: film, video, audio and other electronic arts-based activities were now supported through grants to individuals and both production and dissemination related artist-run centres. Initially, the Media Arts Sector was divided into three separate grant programs, (Film and Holography, Video and Audio, plus Integrated Media). The role that the arts

${ }^{227}$ Association acadienne du cinema (Moncton), Atlantic Filmmakers' Cooperative (Halifax), Funnel, CFMDC (Toronto), Cinema Libre, Films du Crépuscule, Cinéma Québécoise (Montréal), New Brunswick Film Coop (Fredricton), Saskatchewan Filmpool (Regina), Winnipeg Film Group.

${ }^{228}$ Fringe Research, Open Space Gallery, Vidéographe, Video Véhicule.

${ }^{229}$ Canadian Film Group (Ottawa), National Film Theatre (Kingston), and the Toronto Super Eight Film Festival.

${ }^{230}$ Art Metropole, A Space Video (Toronto), Centre for Art Tapes (Halifax), and TBA-TV [Television by Artists] (Vancouver).

${ }^{231}$ Michael Snow got the lion's share at $\$ 30,000$, with Norma Bailey following second at $\$ 15,000$.

${ }^{232}$ Canada Council, Policy Options for the '80's, p. 21. 
community itself played in the creation of the Media Arts Sector is evident.

However, even as the arms of cultural policy finally embraced Canadian independent media arts culture, what had become of the Pelletier mandate that intended that the Canada Council manage the conservation of works produced through such artistic practice? Indeed, policy governing the preservation and archiving of audiovisual materials within Canada had followed its own historical trajectory, which will now be addressed in Chapter Three. 


\section{Chapter 3: The Development of Federal Policy Governing Audiovisual}

\section{Archival Practice in Canada - Key Issues}

The attitude within archival institutions toward the preservation of audiovisual documents during the $20^{\text {th }}$ century carries with it a distinct ethos, one that sheds light on the growth and development of basic archival policy and contextualizes the preservation crisis currently facing Canada's media art community. By 1898 , Boleslav Matuzewski, a Polish cinematographer working for Tzar Nicolas II, had already published a manifesto in Paris, "calling for the establishment of a world-wide network of archives to acquire and conserve the product of this new marvel of technology, this new source of history." ${ }^{233}$ Sam Kula writes, however, that as early as 1900, the Ethnographic Congress in Paris urged anthropological museums to add suitable films to their collections. "The mere possession of the potter's wheel, a number of weapons or a primitive loom is not sufficient for a full understanding of their functional use; this can only be handed down to posterity by means of precise cinematographic records." ${ }^{, 234}$ As such, the perception that only certain audiovisual records were acceptable within the archival environment began to fashion acquisition policy immediately, which would not only affect the pursuit and selection of subsequent moving image collections, but of course also limit the ability of historians to reconstruct those aspects of history portrayed or contained within this new medium, including the cultural development of filmic art practices.

${ }^{233}$ Kula, p. 5.

${ }^{234}$ Sam Kula, The Archival Appraisal of Moving Images: a RAMP Study with Guidelines, (Paris: UNESCO, 1983), p. 6. Originally from Francis Speed, "The Function of the Film as Historical Record," in African Notes, Vol. 6, 1968. 
The perception of the worth of the moving image among most archivists shifted only slightly in the early decades of the $20^{\text {th }}$ century, as cinematographic records became further entrenched in the anthropological paradigm and as such, were acknowledged primarily as evidence of human interaction. In this environment, films were not viewed as cultural products in and of themselves, but rather, as images that documented "the slice of life as the cross-section of a nation and a people., ${ }^{, 235}$ As a result, "Even as moving images in the twenties and thirties began to be harnessed in the service of national and international ideologies, and as the impact of moving images as shapers of public opinion and moulders of public taste began to be recognized by politicians and advertisers alike, there was no concerted effort to systematically acquire and conserve the moving images of one generation for the enjoyment and edification of those to follow."236

Chapter Three focuses, therefore, on the development of archival policy in Canada as it knits together key policy issues that arose from within the film, the arts and the archival environments. For beyond the influence of the international archival domain, in Canada it has been the confluence of concurrent policy developments in these three strands of the cultural arena that has lead to the current preservation crisis within the media arts community. The slow emergence of Canadian federal cultural policy regarding the moving image within this trifecta has greatly influenced the contemporary predicament that leaves the independent media arts community devoid

\footnotetext{
235 Ibid.

${ }^{236}$ Kula, p. 7 . Emphasis mine.
} 
of a systematic preservation strategy to care for its contribution to Canadian cultural history.

\section{Establishing the Worth of the Moving Image in Canada}

Public Archives Canada (PAC) was established in 1912 when Canadian archivists were intent on safeguarding primarily paper-based collections, separating these according to physical characteristics and common usage and thus, creating specialists who handled historical textual documents such as government records, maps, stamps, etc. In Canada, moving images were not preserved in Canada's national archive, but certain kinds of audiovisual material were gathered within the administrative infrastructure of Britain's Imperial War Office. Indeed, this initial urge to safeguard such material was linked to the need to foster patriotism in Canada, through the promotion of Canada's participation in the commonwealth war effort. When Canada joined the War Office Cinematographic Committee (1916), related moving images were thus collected primarily so as to provide footage for reuse in newsreels. And as Charles Backhouse documents, "All wartime negatives and prints were stored in the War Office archives, later the Imperial War Museum."237 Hence, unlike some international counterparts, Canada's first repository for moving images resulted from the wish to provide access to contemporary footage for reuse in the compilation of colonial newsreels, not because of any consideration for their longterm archival significance.

${ }^{237}$ Backhouse, p. 5. He adds that this was also "the first recorded instance of government participation in any major way in film production and distribution." 
As detailed in Chapter One, the need to promote immigration and trade also held prominence within Canada and during this era, spurred an increase in the federal government's commitment to the production of moving images through the Trade and Industry Bureau. Further efforts to actively distribute these films established a centralized film repository at Canada House in London, England. Given that such early government productions were widely distributed throughout the Commonwealth, in Belgium, Holland, Switzerland, and across the West Indies, South America and into the Far East, efforts to ensure that only the best prints circulated also resulted in increased attention over the care of the collection. This provides one of the earliest examples of nascent archival policy relating to the physical and intellectual control of audiovisual material on behalf of Canadian film.

As the Canadian public became increasingly receptive to dramatic film, and national cinemas grew in various countries around the world, committed cultural activists continued to rally around various preservation concerns that pertained to archival practice and the governance of moving image collections. ${ }^{238}$ But it was the introduction of sound technology that was perceived as the greatest threat to early film history; as audiences embraced the talkies, silent films were no longer commercially competitive and there were grave concerns that prints would be junked en masse at the end of distribution circuits. A devoted network of international activists grouped together to address the preservation issues, led by Henri Langlois

${ }^{238}$ Between 1894-1912, the United States of America was collecting fossilised versions of motion pictures through the Library of Congress. These paper prints were pulled from the original nitrate films and although the images were used quite simply to register copyright, by 1912 , new American legislation had made room for the deposit of moving images as a distinct art form. http://mic.imtc.gatech.edu/preservationists portal/presv timeline.htm. Accessed on August 9, 2005. 
(La Cinémathèque Française, France), Ernest Lindgren (National Film Archive, United Kingdom), Iris Barry (Museum of Modern Art, New York), and Gustave Lanctôt (Public Archives Canada).

Indeed, Lanctôt is referred to as Canada's 'first preservation pioneer, ${ }^{, 239}$ and although PAC would not receive the assent it needed in 1938 in order to join the newly formed lobby group, International Federation of Film Archives/Fédération Internationale d'archives du film (commonly known as FIAF), it was these circumstances, this sense of urgency, that provided the impetus for the organization of Canada's first audiovisual archive with PAC, one "specifically devoted to the acquisition and conservation of moving images." ${ }^{240}$ For as David Lemieux reports, up until this time, annual reports from PAC listed no film acquisitions; although audiovisual materials had become the responsibility of the Pictorial Division, there was no support for any official policy that would govern the systematic appraisal and selection of moving image documents. ${ }^{241}$ In fact, when the Cinematographic Division of PAC was finally established in December 1937 , there was very little experience or preservation expertise vis-à-vis audiovisual documents within the national archive.

Without acquisition policy, Kula claims that audiovisual accessions "took on the character of accident, or administrative convenience, or allegience [sic] to fashion in selecting the critical and/or popular successes of the day." ${ }^{242}$ Internationally, great debates raged over who, and indeed how, moving image material should be chosen

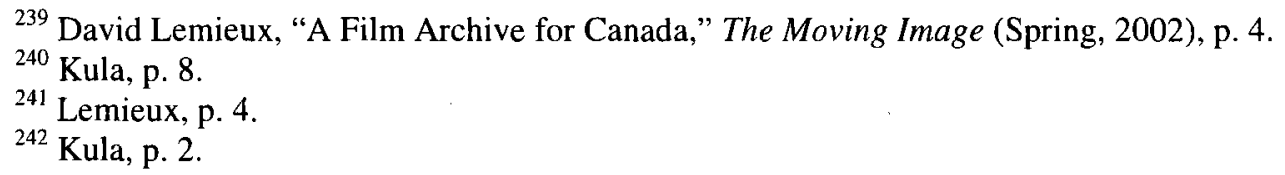


for the archival environment. In keeping with ethnographic propensities, some felt that it was the responsibility of archives to select in order to reflect society. Highly influential among the cultural activists grappling with these issues, however, was Langlois, who felt strongly "that any selection policy was indefensible, that no archivist had the right to play God in determining which films would live and which would die." 243 Indeed, as early as 1922 , Hilary Jenkinson, had also claimed that "neither the historian nor the archivist should share in the creation of archives.",244

David Lemieux asserts that at PAC, however, "Canadian film archiving practices can be traced to a small number of individuals whose personal touches can be recognized in their acquisitions." 245 Indeed, Lemieux claims that, "The first selection criteria regarding the Canadian film archive was in the hands of one man, resulting in an entirely subjective policy based on what he believed to be of greatest significance to Canada.... it was Lanctôt personally who actively sought out films of Canadian interest from producers." 246 Lanctôt, it is said, had a penchant for newsreels, therefore the earliest audiovisual material to be archived within the Cinematographic Division of Public Archives Canada included Associated Screen News of Montreal, Movietone News of New York, and Pathé News of New York. ${ }^{247}$ Tellingly, very few moving images from among the first independently produced dramatic Canadian film works remain, and those now held in the vaults of

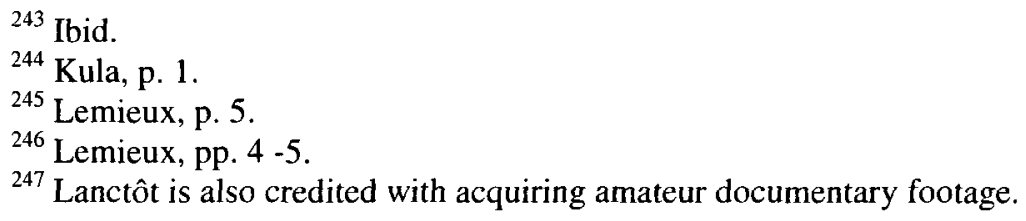


Library and Archives Canada (LAC) exist largely as a result of repatriation efforts by contemporary audiovisual archivists. ${ }^{248}$ By way of example, the Canadian Feature Film Index exhaustively lists Canadian films made from 1913-1985 and indeed, Canada's first feature film, Evangeline (1913) has vanished. Nor are most of the early short-form films any longer available to researchers or the Canadian public, including most of those created by the independent filmmakers referenced in Chapter One. ${ }^{249}$

\section{Calls for Federal Commitment to Canadian Moving Image Heritage}

When in 1941 , by Order in Council, the federal cabinet officially transferred the powers of the Canadian Government Motion Picture Bureau to the National Film Board of Canada, the NFB inherited the old War Office Archive, while the shortlived Cinematographic Division was dismantled within PAC. Yet, even as the newly minted NFB continued to emphasize the production and distribution of film as an educational document, they appeared to be less committed to archiving film than they were intent on providing a contemporary public with access to film prints, both Canadians at home and an international community abroad. Through increasingly well-defined inter/intra national distribution circuits, public access remained the dominant basis for establishing Canadian film collections.

However, by the mid- $20^{\text {th }}$ century, just as activists within the independent film and arts communities were stepping in to pressure the Canadian federal government

\footnotetext{
${ }^{248}$ Canada's national archive began as Public Archives Canada (1912), changed name in 1985 to become National Archives Canada (NAC), and most recently turned into Library and Archives Canada (LAC) in 2004, after the merger of NAC and the National Library of Canada.

${ }^{249}$ In addition to the Canadian Feature Film Index, the reader is also encouraged to source from the extensive account of early Canadian film history written by Peter Morris.
} 
to create policy on behalf of cultural affairs, audiovisual issues also took to the archival stage. In 1948, Hye Bossin, editor of the Canadian Film Weekly, wrote a manifesto calling for the establishment of a Canadian film archive. Perhaps prophetically, he stated that "even now, when Canada has just begun the march toward its great destiny, it is strange that such a powerful industry and art as the moving picture should be without historic records in places designed to house them. How ridiculous will it seem several generations from now. ${ }^{250}$ Indeed, as the cultural proletariat networked throughout Canada, value-laden distinctions that had separated the issues of high art from those of communal edification and public consumption of commercial entertainment by the masses, all now converged within nation-wide activist forums. As documented in Chapters One and Two, the utter lack of federal cultural policy was underscored by both the arts and the film communities, and concerns over audiovisual preservation likewise arose to entwine with these dissident voices as Canadians demanded action from their federal government.

By 1948, William Kaye Lamb was the Dominion Archivist at PAC and he responded to Bossin's article by writing to the NFB, as follows: "I don't think the Archives [PAC] alone could get very far with the project [of establishing a Canadian film archive]. On the other hand, if the film industry itself is interested, or could be interested, and if an agreement could be arrived at whereby films would be deposited regularly in an Archives collection, then I think it is entirely possible that something

\footnotetext{
${ }^{250}$ Lemieux, p. 10. Originally from Hye Bossin, "A Book Review and an Appeal for a Canadian Film Archive," in Canadian Film Weekly, vol. 14, no. 4 (January 26, 1949), p. 12.
} 
might be arranged."251 In fact, throughout the Royal Commission on National Development in the Arts, Letters and Science (1949-51), PAC would remain focused on being a public records office; they did not lobby the Massey Commission on behalf of the creation of an archival moving image collection.

Instead, the lobby for a film archive came from the Canadian Film Institute, a non-profit organization that would soon be supported through the first film-related grant issued by the Canada Council (1958). The CFI, which had emerged newly named from its parent organization, the National Film Society, in 1950, had remained dedicated to its mandate, to the "study and appreciation of the technique and art of films of an artistic or experimental nature." ${ }^{252}$ Again, as was the case at the War Office Archives, at the Canada House in the UK, and at the NFB, at the CFI it was the provision of access to the acquired films that provided the dominant motive and inspired collection. Interestingly, Kula documents that "there were only a handful of archives throughout the world actively acquiring and conserving motion pictures in the first fifty years following the evolution of cinematography, and that those were exclusively non-governmental museums and cinémathèques." ${ }^{253}$ Would the CFI be seen as well positioned to take on a role as the caretaker of Canada's audiovisual heritage?

In 1951, the Massey Report had recommended "that responsibility for maintaining a national film collection be left with the National Film Board, that this

\footnotetext{
${ }^{251}$ Lemieux, p. 11.

${ }^{252}$ Yvette Hackett, p. 137.

${ }^{253}$ Kula, p. 3.
} 
collection be developed not merely as a record of photographic art and techniques but as an historical record of events of national importance." ${ }^{254}$ Yet the NFB, like the War Office Archives and the Exhibits and Publicity Bureau before it, had traditionally cared only for the government works produced within the parameters of its own institutional purpose. The continuance of any such strategy would consequently leave independent productions beyond the vaults, but would the CFI be capable of providing even the most basic of preservation practices, including the intellectual and physical controls that were once afforded to print traffic of government-produced works in the collection at Canada House in the UK?

The NFB itself was painfully aware of the pressing need for improved physical conditions that would properly care for its charge, which included works on highly volatile nitrate stock. ${ }^{255}$ The Board had indeed prepared reports requesting the establishment of new vaults and had also joined the Canadian Film Archive Committee (1951-1957), a group of professionals that boasted an impressive inaugural membership, including Dominion Archivist W.K. Lamb, Hye Bossin of Canadian Film Weekly, independent filmmaker J. Roby Kidd, and the Head of the NFB, W. Arthur Irwin. While the Canadian Film Archive Committee urged the federal government to take the matter of film preservation into hand, the membergroups had each quite individual reasons for sitting at the table, which sheds further

${ }^{254}$ Government of Canada, Report from the Royal Commission on the National Development in the Arts, Letters and Sciences, 1949-1951 (Ottawa: King's Printer, 1951), p. 309.

${ }^{255}$ It was not until 1950 that acetate-based safety film was introduced to replace selfexplosive nitrate stock. 
light on one of the basic issues that has continually plagued the ongoing development of audiovisual archival policy in Canada - why archive audiovisual work?

On behalf of PAC, Lamb wanted some sort of mandatory deposit arrangement that would see producers sharing the responsibility and cost for the preservation of their own work. If independent filmmakers would supply the archives with prints, PAC could care for them and thus, the prickly task of developing acquisition policy and selection criteria to meet meagre (and changeable) budgetary allotments within the largely ambivalent public institution would become mute in the process. Kidd, a representative of commercial independent filmmakers, was more interested in creating a bridge between the archives and those independent producers who needed increased access to archival footage for reuse. Bossin, on the other hand, urged the furtherance of policy to provide for the systematic preservation of filmic work so as to establish the essence of Canadian cultural heritage as recorded through film, which would in turn allow for increased dialogue and an expanded sense of nationalism, both across the country and into the future. And the NFB, of course, desperately needed supplementary resources (or a shift in internal institutional policy) if it was to accomplish the far-reaching mandate proposed by the Massey Commission. ${ }^{256}$

Perhaps unsurprisingly, the Canadian Film Archive Committee was unable to make any progress and the group disbanded in 1957. Understandably, the independent film community, receiving little aid from the federal government for the

${ }^{256}$ According to David Lemieux, PAC had in fact acquired the work of the Canadian Army Newsreel Division from London, England because, "The Army Newsreel Division, represented by Col. William G. Abel, aware of the NFB's already infamous reputation, knew that films stored by the NFB stood a very good chance of being lost or destroyed by poor storage conditions." Lemieux, p. 14. 
continued production, distribution or exhibition of their work, would find it difficult to self-finance an archival initiative such as that suggested by Lamb. Yet without such financial participation, it appeared as though PAC itself was unwilling to invest in the systematic preservation of independent Canadian film. Tragically, nor did the NFB invest in its collection and, also unable to raise additional collateral to meet its preservation needs, in 1967, during Canada's centenary celebrations, the largest collection of legacy Canadian film was destroyed in a disastrous nitrate fire, which occurred in the NFB vaults at Beaconsfield, Québec.

\section{Preservation Policy for Audiovisual Records}

The destruction of half a century of formative Canadian moving image history in the Beaconsfield fire led to recrimination that directly blamed the Canadian federal government for its lack of leadership; federal governance, it was felt, should have produced a policy infrastructure that would adequately safeguard such rich cultural heritage within Canada's national institutions. Because of its role as a national cultural agency, one whose funding mechanisms already supported the CFI, which had indeed established its Canadian Film Archive in 1963, the Canada Council became implicated in the resultant flurry of policy activity. ${ }^{257}$ Council, as has also been noted, had become increasingly involved with the establishment of various film collections through its financial support for 'non-governmental cinematheques' and

${ }^{257}$ The Canadian Film Archive had been immediately accepted as Canada's first full member within the International Federation of Film Archives/Fédération Internationale d'archives du film (FIAF). 
artist-run distribution centres, which were likewise engaged in the publication, distribution and exhibition activities that promoted Canadian film culture..$^{258}$

However, talks were also now fully underway at PAC to assess the feasibility of establishing a film archive with divisional status within this public institution. Beginning with the development of the Sound Archive (1968), PAC also started what became known as the nitrate conversion program shortly thereafter. And in the Annual Report of the following year, the Picture Division also announced that it was creating "archival programs in relatively new media: sound recordings, heraldry, and motion picture film. ${ }^{, 259}$ PAC then commenced actively collecting Canadian audiovisual materials in earnest, acquiring an astounding 14,000 reels of film by $1970 .^{260}$

Although the federal institution appeared finally ready to fully embrace audiovisual materials, the assessment of who would wield control over Canada's film archive was still being analyzed by the Canadian government. ${ }^{261}$ Guy L. Côté, independent producer, activist and prominent member of the feature film community, submitted a report in 1970 that had been commissioned by Secretary of State, Un Politique fédérale des archives cinématographiques. In clear opposition to proposals for continued support of the Canadian Film Institute's Canadian Film Archive, Côté

\footnotetext{
${ }^{258}$ As stated in Chapter Two, in addition to funding the CFI in 1958, as early as 1965 the Canada Council had also funded la Cinémathèque Canadienne (Montréal), the Pacific Cinémathèque (Vancouver), the Canadian Filmmaker's Distribution Centre and Art Metropole (Toronto). See footnote 212 and page 73 for further details.

${ }^{259}$ Public Archives Canada, Annual Report, 1959-1969 (Ottawa: 1971).

${ }^{260}$ Lemieux, p. 15.

${ }^{261}$ For an in-depth account of this entire period in Canadian archival history, the reader is encouraged to read David Lemieux's journal article, A Film Archive for Canada.
} 
underscored the need for a federal infrastructure that would be able to accommodate the many forms of Canadian audiovisual material, and he categorically dismissed the possibility that any existing archival institution beyond federal government control would be capable of handling the overall volume. By now, the mass of audiovisual materials that would need attention was deemed to include not only what was left of the works under the care of the NFB, but also its future output and the bulk of Canadian-produced television programming. Further, imminent feature-length productions from the newly established Canadian Film Development Corporation would have likewise been in the forefront of Coté's mind, given his heavy involvement in this cultural arena. ${ }^{262}$

It is also of significance that it was only now, at this juncture in time, that the International Council of Archives first recognized moving images (1972). ${ }^{263}$ And thus, while it had become clear that audiovisual records were indeed suitable archival contributions to national cultural heritage, the issue of what types of audiovisual material would finally form a federal national moving image archive quickly became imbedded within overriding concerns over resources versus mass, which included issues of media-appropriate physical infrastructure - volume control, climate control, vault space - and of course, basic financial dispensation.

\footnotetext{
${ }^{262}$ Established in 1967 as the Canadian Film Development Corporation, the organization would change its name to Telefilm Canada in 1984, "to better reflect the full range of its activities in film and television." From the Telefilm website, www.telefilm.gc.ca, downloaded March 18, 2003.

${ }^{263}$ Kula cites a report by Wolfgang Kohte, "Archives of Motion Pictures, Photographic Records and Sound Recordings: A Report Prepared for the XIIth International Congress on Archives, Moscow," which was delivered to the Moscow Congress of the International Council of Archives, August 21-25, 1972.
} 
Indeed, as the National Film Archives Division grew in stature at PAC, the Canadian Film Archive withered within the CFI, "despite many attempts to get the funding necessary to carry on this important function." ${ }^{264}$ In 1972 , the film collection at the Canadian Film Archive became one of the first major film acquisitions at PAC. Within a brief that was submitted to the Canada Council sponsored Film Colloquium for Non-profit Film Organizations (1979), it was reported that, "In the two years preceeding [sic] this transfer, the [Canadian Film] Institute was forced to sell to the PAC large increments of archival material in order to survive financially." 265 of course, this reflected poorly upon the Canada Council, underlining its inability, or unwillingness, to provide the basic resources required by its client, the CFI, resources that would have perhaps ensured the survival of the Canadian Film Archive.

Finally, on January 29, 1976, the Canadian government formally established the National Film Archives (NFA). As a new branch of Public Archives Canada, the NFA was awarded "full funding to carry out its operations, with significant growth funding to be made available in the future." 266 According to Richard Lochead, "The mandate of the new Division was large and comprehensive: 'to consolidate and coordinate the archival administration of production resources of the Canadian Broadcasting Corporation, the National Film Board, CTV television network and other producing organizations, to assure conservation of film in the national interest

${ }^{264}$ This quotation was taken from page one of a document simply entitled "Canadian Film Institute." Found in June 2004, within the textual archives of the Independent Media Art Alliance archives (Montreal), it is dated November 1979. No author is credited but a list of the Board of Directors that follows at the end of the report cites people who would go on to further shape Canadian film history, including: Michael Spencer, Wayne Clarkson, André Lamy, and Sydney Newman.

265 "Canadian Film Institute," p. 2.

${ }^{266}$ Public Archives Canada, Annual Report, 1976-77 (Ottawa: 1977), p. 101. 
and to assure access for scholarly reference purposes for all Canadians." 267 The basic business of the day, restructuring for the large-scale acquisition and preservation of long neglected Canadian audiovisual records, continued.

\section{The Canada Council and Film Conservation Policy}

That the Canada Council could not (or would not) adequately fund the CFI to safeguard this single film collection, from among the many that were building within the cinémathèques and the distribution centres that Council now supported, directly calls into question the 1972 policy directive to Council by Secretary of State Minister Gérard Pelletier. While assigning to the Canada Council a more clearly defined role for its experimental film-based activity, Pelletier had also stipulated that Council be responsible not only for the spread of film culture, but also that it work to conserve film, as outlined in Chapter Two. ${ }^{268}$ Yet the Canada Council, working to strengthen its ties with the media arts community, appeared to be separating itself from such thorny (and expensive) archival issues as may have been implied by the Pelletier directives of $1972 .^{269}$

Symbiotically involved with an increasingly militant, multi-media and interdisciplinary client base, Council was strategizing how best to manage its internal policy to meet the changes embedded within a growing community of technologically

${ }^{267}$ Richard Lochead, Audio-visual Heritage in Canada: Survey of Landscape 2009, (Ottawa: Library and Archives Canada, April 2009), pp. 5-6.

${ }^{268}$ See page 76.

${ }^{269}$ For example, when the Canada Council established a Film Collection Program within the Visual Arts Sector in 1974, it is said to have been initiated simply "for the purpose of documenting the results of film production grants." Canada Council for the Arts, "Funding and the Media Arts Sector," Media Arts, 1985: A Brief History of the Development of Media Arts (Ottawa: 1985), p. 1. 
driven artistic practices. Further, the Canada Council did not have a clear mandate from the media arts community to address conservation issues; the newly organized artistic community had instead sounded a general call for the support of increased production and dissemination of film and video across the developing network of artist-run centres in Canada. As has been noted repeatedly throughout Canadian film history, production-oriented activity demands increased access to the public in order to cyclically support creative output. Consequently, Council could be seen to have been actively supporting only one aspect of the Pelletier policy, the spread of film culture. Yet, even as preservation was not part of the day-to-day agenda in the early days of artist-run culture, Council remained mandated to also focus upon the second thread of the Pelletier directives, conservation.

In June 1976, Françoyse Picard, Film Officer at the Canada Council, hosted a nation-wide conference, the Film Resources Colloquium, which focussed solely on preservation, conservation and dissemination. ${ }^{270}$ During the two-day conference, a series of recommendations were put forward, as follows: that the National Film Archive at PAC be recognized as an important part of a national network of film archives; that the NFA be concerned with preserving such aspects of film and related electronic artefacts of long-term interest to the nation as a whole; that the NFA be located in Ottawa and financed by federal funds; and, that it be recognized and understood that regional organizations have different needs and should continue to

\footnotetext{
${ }^{270}$ The invited guests included an array of eminent alumni: Wayne Clarkson, once at the CFI, later to become the head of Telefilm; Fil Fraser, an independent filmmaker who would become a significant player at the Alberta Motion Picture Development Corporation; Jean Lefebvre from Secretary of State; Sam Kula from the National Film Archives; and, Hugh Taylor formerly of PAC.
} 
receive separate funding, "either through the Secretary of State and the Canada Council, or through some similar federal body. Sec. State should create a film archives advisory body for Canada that would reflect the interests of regional archives."271 Clearly, while the national community supported the National Film Archive, regional interests were also represented by Council-funded groups in attendance, groups that articulated the continued need for the diversity of activity contained in pre-existing facilities; artist-run centres specifically noted the critical importance of ongoing recognition and funding for regional dissemination initiatives.

On January 20, 1978, the Canada Council addressed the call for an archival advisory committee and issued a press release announcing that, through the Social Sciences and Humanities Research Council (SSHRC), they had established a Consultative Group on Canadian Archives. The purpose of the Consultative Group was "to examine the function and state of the Canadian archival system, the roles of public and private institutions in the preservation and use of historical records pertaining to Canada, and the implications of Canada Council programs for the development of Canadian archives."272 Ian E. Wilson, then the Saskatchewan Provincial Archivist, ${ }^{273}$ led the SSHRC initiative, and interested groups were invited

There were also two representatives from the independent film community: Leon Johnson of the Winnipeg Film Group, and Gordon Parsons from the Atlantic Filmmakers' Cooperative in Halifax.

${ }^{271}$ Handwritten notes on the agenda as found in the archival papers of the Independent Media Arts Alliance suggest that these recommendations were submitted by Frederick Manter of the Canadian Film Institute (Ottawa), Kirk Tougas of the Pacific Cinematheque (Vancouver), Ken Hughes of the Manitoba Arts Council (Winnipeg), Serge Losique of the Conservatoire d'art cinématographique (Montréal), Robert Daudelin from the Cinémathèque Québècoise (Montréal), and perhaps, Gerald Pratley from the Ontario Film Theatre (Toronto).

${ }^{272}$ Canada Council for the Arts,. Press Release, January 20, 1978.

${ }^{273}$ Wilson became Canada's National Archivist in 1999 and retired from LAC in April 2008, as Librarian and Archivist of Canada. 
to submit briefs before April 15, 1978. Thus, the Canada Council succeeded in firmly aligning the audiovisual archival function with an educational mandate, once again placing moving image preservation adjacent to film's formative, and educative, nation-building roots. Importantly, SSHRC had also just been split from the Canada Council through an Act of Parliament in 1977, neatly redirecting the Pelletier directive.

The resultant proposal from the Consultative Group on Canadian Archives recommended that a National Archival Advisory Committee, as a branch of the national archives, "minister to the entire archival system on the basis of policies and priorities as would be established by the National Archives of Canada." ${ }^{274}$ In fact, the Consultative Group was suggesting that the proposed National Archival Advisory Committee "act as an independent funding and coordinating agency, through which the programs, studies and recommendations for a national 'cooperating system of archives' could be instituted." 275 Given upcoming revisions to the Public Archive Act, it was expected that PAC would facilitate the independent agency, and somehow "provide for the coordination of archival planning throughout the country, in order to make more efficient use of our total archival resources." 276 However, according to records from consultations that took place under the leadership of the 1982 Federal Cultural Policy Review Committee, the recommendations of the Consultative Group on Canadian Archives were not well received by either PAC or the Association of

\footnotetext{
${ }^{274}$ Government of Canada, Department of Communications, Report of the Federal Cultural Policy Review Committee (Ottawa: Minister of Supply and Services Canada, 1982), p. 131.

${ }^{275}$ Ibid.

${ }^{276}$ Ibid.
} 
Canadian Archivists; there would never be such a coordinating agency. ${ }^{277}$ Whether intentional or otherwise, it appears as though the Canada Council had initiated a chain of events that successfully shifted the Pelletier policy issue around the 'conservation' of independent media artworks away from the Canada Council. Yet as the national institution, PAC was clearly not ready, or willing, to embrace such an expanded role as would place them in charge of the coordination of a nation-wide archival infrastructure, one that might indeed have accommodated the independent media arts.

\section{The National Gallery of Canada}

Significantly, the 1972 Pelletier policies had also produced the National Museum Policy, "which aimed at a better distribution of museum and gallery resources across Canada to expose the greatest number of Canadians to their national heritage." 278 The National Gallery of Canada began to acquire media art in the early 1970s, purchasing approximately 160 works in that decade, primarily on film. An increase in commitment to the media art form was evident toward the end of the 1970s, during which time the programming of media art at the National Gallery rose steadily, as it would indeed continue to do throughout the early 1980s, when Rob McFadden became the first part time curator of film and video (1981-85). Notably, the National Gallery of Canada acquired these media artworks as part of the exhibition policy of the gallery; therefore they represent a curated collection of

${ }^{277}$ Ibid.

${ }^{278}$ Jiri Zuzanek, "Democratization of Culture and Cultural Democracy in Canada," in Funding the Arts, Vol. l, eds. H.H. Chartrand, H.S. Hendon, and H. Horowitz (Avignon, France: Feb. 1987), p. 116. Essentially, the publication contains the proceedings of the Fourth International Conference of Cultural Economics and Planning, which took place in Avignon, May, 1986. 
Canadian media art, a reflection of only part of the independent media art landscape.

Yet in 1984 and 1985 alone, 80+ titles were purchased in each year, bringing the total acquisitions in that decade to approximately 320 , an unprecedented volume that has not been matched at the National Gallery of Canada to date. ${ }^{279}$

The National Gallery of Canada continued to buy independent media artworks directly from artists throughout the nineties. In September 1991, Jean Gagnon filled a post that was vacated by Su Ditta in 1990 and became an Associate Curator responsible for media art. Media art acquisition levels remained fairly consistent until he left in 1997, although the figures are skewed somewhat as a result of the over 250 titles that came under the protection of the National Gallery as a result of the ceded collection by Art Metropole in that same year. However, in the first decade of the $21^{\text {st }}$ century, the National Gallery of Canada has purchased a mere handful of independent media artworks. ${ }^{280}$ Most recently, the National Gallery has conducted a study to assess how it might best address the ongoing preservation of its audiovisual collection, much of it on $3 / 4$ " U-Matic video tape; the findings of the final report are not public, however.

${ }^{279} \mathrm{McFadden}$ regularly programmed video in a purpose-built room within the national institution, which was a luxury for video artists. The videos from these programmes were the primary source of acquisitions in the ' $80 \mathrm{~s}$, although not all of the acquired works were by Canadians. In a list obtained from the National Gallery of Canada, produced for the author on May 24, 2006, 948 titles are cited as media art acquisitions, approximately $65 \%$ of which are estimated to be Canadian.

${ }^{280}$ As of 2006, acquisition reports from the National Gallery of Canada detail the purchase of only 21 media artworks for the first six years of the decade. 


\section{The Canada Council Collection}

Meanwhile, Sam Kula, Director of the new National Film Television and

Sound Archives (NFTSA), ${ }^{281}$ had been in dialogue with Picard over the potential acquisition of select media artworks produced through Canada Council grants. On

May 24, 1978, Kula sent a letter to Picard, which read:

...the Council had agreed at one point to let us have copies of the proposals awarded grants so that we would have the opportunity to follow-up on projects or productions we feel should be conserved in the national interest... Several of the recipients of the Senior Arts Grants ... are filmmakers whose contribution is such that we feel that copies of all their productions (whether or not 'commercial' or experimental) should be in the national collection... we are only considering voluntary compliance. As you are aware we may also be of direct assistance to the filmmaker in protecting the original material while the work is being marketed. ${ }^{282}$

The project would finally commence five years after this communiqué, and thus, between 1984 and 1991, 747 audiovisual works, what is known as 'The Canada Council Collection,' came to be archived under a voluntary deposit agreement between the Canada Council and the NFTSA. This represents the only time period during which there has been any large-scale systematic preservation of independent media artworks produced through Canada Council funding at Canada's national archive.

${ }^{281}$ The National Film Archives changed its name to the National Film, Television and Sound Archives (NFTSA) and would later morph to the Moving Image and Sound Archives (MISA), then the Visual and Sound Archives (VSA), until finally settling as a sub-section of the Canadian Archives Special Collections Branch, Film \& Broadcasting, after the 2004 merger that created Library and Archives Canada out of the National Library and the National Archives of Canada.

${ }^{282}$ Sam Kula to Françoyse Picard, May 24, 1978. Kula's offer to archive the original elements required to reproduce prints of films, or dubs from master tapes, would not have been well received by practicing filmmakers, unless these original elements were to remain accessible to the artists, as needed. Deposit agreements that allow such recall by donor are now largely frowned upon within audiovisual archival circles. 
Picard initially provided Kula with a list of 100 film titles, perhaps including those that were collected earlier by the Visual Arts Sector or otherwise amalgamated at Council as a result of funding obligations within the Media Arts Sector, which once required artists to file a copy of their finished work as part of final reporting mechanisms. It is as yet unclear how the materials for the Canada Council Collection were chosen, whether selection criteria were developed beyond Kula's requested list of grant recipients, or whether the media artwork was otherwise hand-picked by the Council or staff at the national archive. ${ }^{283}$ Nevertheless, between 1984 and 1991, the Council transferred a total of 186 films, 546 videos, and 15 audio reels, which were then catalogued in the MISACS database under 32 separate accessions, with six different Council Officers listed as donors. There are several notable artists represented among the legacy works within 'The Canada Council Collection,' which in its totality represents a significant body of early work from the independent media arts community, including an Intermedia sampler, produced by Michael Goldberg between 1970 and $1973 .^{284}$

Since 1991, therefore, the independent media art produced through the Canada Council has not been acquired through any systematic preservation policy at LAC, nor has it been sustained by curators from the National Gallery of Canada. Further

\footnotetext{
${ }^{283}$ The actual deposit agreement has not been located to date; it appears as though, as the technical parameters of the program were fine-tuned, artists were compensated by the Council for costs associated with supplying NAC with archival copies of their work for the national collection.

${ }^{284}$ Without access at this time to Canada Council statistics that attest to exactly how many media artworks were awarded grants and how many of those awarded were completed, it is not possible to draw conclusions as to what percentage of overall media art output 'The Canada Council Collection' represents for this time period. What is clear, however, is that this collection consists of only a portion of the total number of independent media artworks, and obviously, only those produced
} 
distinctions of purpose are critical to increase an understanding of the institutional environment in Canada as pertains to the preservation of audiovisual material, specifically, independent media art. For while museums frequently lend their work, and galleries consistently cull their collections, archives are responsible for the permanent, long-term protection of all records entrusted to them. Given that the acquisition policy of the National Gallery usually entails that the media artwork would also be exhibited (and that artists would be paid), and given that the independent media arts community itself was not concerned with archiving its work in the early days of its existence, arrangements with artists at the National Gallery of Canada may seem a much more favourable and reciprocal relationship than the prospective arrangement between Council and the NFTSA, as the latter saw film prints or video copies deposited, but essentially left the artists with no recompense and without further access to archived material, given that Council itself was designated as donor. Access and the economic right to earn a living from the production of creative materials: these are critical issues within the contemporary independent media arts community.

\section{Fading Away}

While the early decades of the comparatively well-funded NFTSA at National Archives Canada (NAC) succeeded in addressing several key issues pertinent to audiovisual archival policy (the development of acquisition and selection criteria, the 
establishment of intellectual and physical control mechanisms over holdings, the creation of carefully controlled climactic vault space adequate to the containment of volumes of audiovisual records, each medium with disparate needs), by the mid1990s, sustainable funding for ongoing growth management of the breadth of Canadian audiovisual records was proving unattainable.

In The Preservation and the Enhanced Use of our Canadian Audiovisual Heritage: A Passing Heritage (1993), National Archivist, Jean-Pierre Wallot, stated:

For the past ten years at least, it has become increasingly impossible for the National Archives and other archival and cultural institutions across the country to acquire, preserve, organize and make available even the most important elements of our audiovisual heritage. As a result, we risk the irreparable loss of the audiovisual testimonies of the present and of the recent past unless a concerted effort is pursued across the country.... There is recognition that no single archival or cultural institution, including the National Archives, has the means necessary to ensure the safeguarding of all the records of lasting significance... a nationwide strategy is required." 285

Wallot succeeded in his recommendation that a Task Force be established to address urgent archival issues when on March 11, 1994, approval for the Task Force on the Preservation and Enhanced Use of Canada's Audio-Visual Heritage came from the Minister of Communications.

${ }^{285}$ Jean-Pierre Wallot, National Archives Canada, The Preservation and the Enhanced Use of our Canadian Audio-Visual Heritage: A Passing Heritage (Ottawa: December 1993). 'Enhanced Use' was defined as "the preservation of historically significant audio-visual archival records of enduring value" and, "access to and use of them so that these heritage treasures can be used for cultural and economic purposes, with full respect for copyright and related laws." pp. 1-2. 
The Independent Film and Video Alliance ${ }^{286}$ was invited to participate on the Steering Committee of the Task Force. Briefly, as attempts were being made to conduct a nation-wide survey of audiovisual holdings in Canada, led by Jacques Grimard, the Independent Film and Video Alliance (IFVA) was invited to send the survey and questionnaire to its member groups. The IFVA chose to forward this document predominantly to those member groups that were distributors, including the Canadian Filmmakers Distribution Centre (CFMDC) and Vtape, both from Toronto, and the Winnipeg Film Group and Video Pool, both located in Winnipeg.

On January 31, 1995, the IFVA responded to the Task Force with a letter stating that the independent film and video community was unable, on its own, to handle preservation and restoration of the thousands of works that represented its membership, noting that much of its legacy work was in dire need of restoration. The IFVA proposed the creation of a restoration centre and supported working cooperatively with the NAC to develop appropriate strategies that would help to achieve solutions to the preservation and archival problems facing the independent media art's community. ${ }^{287}$ In keeping with developments within the archival community at large, the IFVA saw clearly that their work was at risk for many of the reasons that had been consistently raised in years past: insufficient funding, lack of appropriate facilities, changing formats and subsequent technological obsolescence, the rigour of establishing standards for physical and intellectual control (access), and of course, the

\footnotetext{
${ }^{286}$ First known as the Independent Film Alliance Cinéma Indépendent (est. 1980), this organization was re-named the Independent Film and Video Alliance (IFVA) for a brief period but is currently known as the Independent Media Arts Alliance (IMAA), all of which reflects shifts in technology and media arts-based practices.
} 
lack of inclusive, systematic selection criteria and acquisition policy within major, federally funded cultural institutions in Canada.

In 1995, the final report from the Task Force on the Preservation and Enhanced Use of Canada's Audio-Visual Heritage was released as Fading Away: Strategic Options to Ensure the Protection of and Access to our Audio-visual Memory. The Task Force proposed 20 recommendations and a three-year action plan. ${ }^{288}$ From the Fading Away report, the Alliance for Canada's Audiovisual Heritage was created in June 1996, which became a consortium of "producers, creators, distributors, users and collectors from across Canada who are dedicated to promoting the preservation of Canada's audiovisual heritage and to facilitating access to and usage of regional and national collections through partnerships with members of the audiovisual community." 289 The mandate of the Alliance for Canada's Audiovisual Heritage was "to coordinate a national stategy [sic] for this critical heritage work and to collect funds to restore and copy materials of the past that need immediate attention... [as well as] pro-active preventive mechanisms for the future to ensure long term preservation of and access to our Canadian audiovisual heritage." 290 In some ways, the Alliance was positioning itself to undertake part of the work that had been proposed by the Consultative Group on Canadian Archives in

${ }^{287}$ Kim Tomczak, (Executive Director, Vtape), to Jacques Grimard, - letter on behalf of the IFVA, dated January $31,1995$.

${ }^{288}$ Government of Canada, Task Force on the Preservation and Enhanced Use of Canada's Audio-Visual Heritage, (Ottawa: 1995), p. 47. In conjunction with the report, the NAC also produced a short video, Fading Away, which summarizes key issues raised by the study.

${ }^{289}$ Brian Robertson, Feature Film Policy - Some Comments, Alliance for Canada's AudioVisual Heritage, March 1998. This was a submission to the Canadian Feature Film Review by Robertson, then president of the Alliance. Found on http://www.pch.gc.ca/progs/ac-ca/pol/cinemafilm/pubs/sub78.htm, downloaded April 8, 2005. 
the late 1970s. Yet while slow progress has been made across Canada regarding the establishment of institutional databases that list audiovisual inventory, an invaluable research tool, ${ }^{291}$ most of the goals of this newest advocacy group were not realized.

The Alliance for Canada's Audiovisual Heritage has since morphed into the Audiovisual Preservation Trust (1999), more commonly known as the AV Trust. In June 2003, the organization facilitated a detailed report, the Canadian AV Vault Inventory, ${ }^{292}$ while also providing funding through the Educational Assistance Program, which allowed the Canadian Filmmakers Distribution Centre, as one example, to produce several DVDs for the educational market, including Made by Hand: Experimental Works for Educational Environments, Key Canadian Documentaries, and Winter Kept Us Warm (David Sector, 1965). Perhaps most visibly, the AV Trust also contributed to the canonization of Canadiana by regularly hosting the MasterWorks ceremonies, which "recognize 12 culturally significant classics each year, drawn from the archives of the Canadian film, radio, television and sound recording industries."293

${ }^{290}$ Ibid.

${ }^{291}$ For example, La Cinémathèque Québécoise has a detailed online database that makes it easy to avoid duplicating its efforts, especially given that an informal agreement among audiovisual archivists resolves not to acquire work if it is already safeguarded within another institution.

${ }^{292}$ Villeneuve Media Technologies Inc., "The Canadian A-V Vault Inventory Report," AudioVisual Preservation Trust, 2003. This is an adequate starting point for those who wish to assess the kind and number of vaults that currently contain specific moving image collections in facilities designed for long-term storage, conservation and/or preservation. The report also outlines significant technical issues surrounding such ongoing preservation initiatives. It is available on the AV Trust website: http://www.avpreservationtrust.ca Last accessed April 12, 2004.

${ }^{293}$ AV Preservation Trust, MasterWorks 2006: Jury Guidelines, Version 1.2, May 2006, p. 2. MasterWorks has been running since 2000, and Canadian independent media artist, Michael Snow, was honoured in 2006, for his film, Wavelength. A full list of all award winners for each category is available on the AV Trust website, as is a list of those awarded through the Education Assistance Program. 
These efforts were commendable, in that they heightened awareness of the need to preserve Canadian audiovisual work, which included the promotion of discourse on independent media arts practices. In spring of 2008 , however, the Conservative government of Canada, led by Prime Minister Stephen Harper, cut funding to the AV Preservation Trust, among other cultural programs. As reported in The Hill Times "The Conservative government has announced the cancellation of the A-V Preservation Trust $(\$ 300,000) \ldots$ effective March 31, 2009."294 The MasterWorks program has since been suspended and the organization itself is not expected to survive into the future.

\section{Contemporary Preservation Efforts within the Independent Media Arts Sector}

Focused attention on preservation activity within artist-run centres themselves will perhaps elucidate some of the contemporary struggles that independent media art centres are now facing as they seek to safeguard their own work. The Canadian Filmmakers Distribution Centre, founded in 1967, was "born from a desire within the filmmaking community to establish an institution that would increase the distribution opportunities for Canadian short, non-commercial, artist-driven independently produced films, ... a distribution centre which would contribute to the creation of a culture receptive to artist-made films and which would remit royalties for the

${ }^{294}$ The Hill Times, http://www.thehilltimes.ca/html. Last accessed June 8, 2009. AV Trust President, David Novek, posted an open letter on the website of the Trust in response to cuts to funding. http://www.avpreservationtrust.ca, last accessed June 9, 2009. Note that total funding for the Trust comes from LAC, the NFB, Telefilm Canada, and CBC, although the latter withdrew in 2008. 
exhibition of this work." 295 This centre acknowledged the ongoing deterioration of its heritage film collection in 2006 , when a sophisticated, professional Collection Assessment was conducted to ascertain the condition of its 2,395 titles, of which 1,528 are Canadian. Stabilization and climate-controlled storage conditions are required, as are improved methods for ongoing print maintenance; funding for these important activities is imperative, yet remains unattainable.

Vtape, incorporated in 1983 , houses a collection of 3,760 titles on video, 2,978 of which are Canadian. Committed to preserving its history, Vtape operates a video conservation lab that is fully equipped to migrate tapes from obsolete stock, which is done on a case-by-case, cash basis; they now have the equipment necessary to recover video from $1 ", 1 / 2 "$ open reel, $8 \mathrm{~mm}, 3 / 4 "$ U-Matic, and all VHS and Betamax formats. ${ }^{296}$ Between 1989 and 1990, Vtape also deposited between 20-30 legacy video tapes with NAC, including works by senior video artists, Lisa Steele, Vera Frenkel, Colin Campbell and Rodney Werden, although it is not clear whether or not these works, or indeed any of those within the Canada Council Collection, will become part of the proposed LAC Audiovisual Migration Action Plan between 2009-

${ }^{295}$ All statistics on the distribution centres that follow have been taken from general organizational information within separate applications for funding to the Canada Council, Media Arts Section, through Annual Assistance to Distribution Organizations, November 2005. These documents were accessed with permission from Canada Council Officer, Kelly Langgard, and were cited in an unpublished research report commissioned by the Canada Council, which remains under copyright with this author. Wozny, "An Introduction to Media Arts Preservation Initiatives in Canada" pp. 30-31.

${ }^{296}$ It should be noted that the Film and Broadcasting sector of Library and Archives Canada does not generally accept $1 / 2$ " open reel, 1" open reel, D1, D2, D3, Sony Betamax videocassettes, or any camcorder formats, such as Hi-8 or VHS; such obsolete formats can no longer be supported. Please refer to footnote 2 . 
2014..$^{297}$ With similar commitment to research and education, Vtape also hosts the website, Video Art in Canada. ${ }^{298}$

Video Pool is currently the only Canadian artist-run centre that hosts a climate controlled vault, with 1,309 titles, of which 1,051 are Canadian. They have successfully garnered the funds they need to conduct a complete Vault Collection Assessment, with a view toward implementing procedures that will allow for improved intellectual control over their holdings. They too are committed to preservation and are currently looking for funding to migrate all of their $3 / 4$ " tapes. As of 2005 , all work submitted from the independent media arts community was accepted into the vaults; submasters were migrated to Beta SP for those contemporary works eligible for exhibition or distribution, or otherwise copied to DVD in order to provide community access for research and programming.

Of the other six distribution centres within the independent media arts sector, with a collective total of 3,877 Canadian titles, a handful of works have been transferred to provincial or municipal archives, while the centres themselves continue to lobby for increased awareness of the plight of their collections. Indeed, much of the early video produced by the independent media arts community that is not in distribution remains, to this day, unprotected on the shelves of artist-run centres, with original elements often languishing in the homes of artists across the country.

${ }^{297}$ For more details on the LAC Migration Plan, please refer to footnote 2.

${ }^{298}$ This is a website sponsored by the Department of Canadian Heritage through the Virtual Museum of Canada Investment Program. This site is also linked to Video Art Research Database, which hosts a searchable database of the Vtape inventory and also provides bibliographic information for a wealth of textual material pertaining to video art. www.videoart.virtualmuseum.ca 


\section{From Script to Screen}

In 1998, a new policy directive began with in-depth research and consultations that focused on the feature film industry across Canada, which produced the report, $A$ Review of the Canadian Feature Film Policy. Key preservation financing was issued by the Department of Canadian Heritage beginning in 2000 , through an initiative entitled From Script to Screen: New Policy Directions for Canadian Feature Film, a program that partially funded preservation activity within Library and Archives Canada and the AV Preservation Trust. ${ }^{299}$ Through Script to Screen Canadian Heritage invested in a series of feature film initiatives with an initial \$15 million in $2000-01$, then $\$ 50$ million per year henceforth. Without a doubt, the small portion of this money that was provided to the preservation community has been useful; initially, $\$ 750,000$ per year was shared between Library Archives Canada $(\$ 600,000)$ and the AV Preservation Trust $(\$ 150,000)$, which was governed over the period of a three-year Memorandum of Understanding. ${ }^{300}$

At LAC, the Canadian Feature Film Preservation Fund was split evenly between preservation initiatives and acquisition activities, and this resulted in the acquisition of a relatively significant number of feature films. First of all, in the ensuing nine years LAC has been able to directly purchase copies of independently produced feature-length work, though not from individual filmmakers but rather,

\footnotetext{
${ }^{299}$ Government of Canada, Department of Canadian Heritage, From Script to Screen: New Policy Directions for Canadian Feature Film (Ottawa: Minister of Public Works and Government Services Canada, 2000).

${ }^{300}$ The funds administered through each three-year Memorandum of Understanding between Library and Archives Canada and Department of Canadian Heritage, which is up for a third review in March 2010, have fallen with each successive term. The constant renegotiations over the MOU do not
} 
from labs, so as to maintain control over the archival considerations requisite to longterm preservation of film prints and video dubs. ${ }^{301}$ Script to Screen also took to heart the 1948 proposal made by then Dominion Archivist W.K. Lamb, which suggested that the film industry itself ought to commit to preservation efforts by depositing feature-length film prints with the national archive. Telefilm Canada now requires "that the cost of preservation copies be included in production budgets,",302 which means that Telefilm's feature-length producers must comply with the deliverables cited in their contracts, which reflects the mandatory deposit agreement between Telefilm and LAC and provides incentives that ensure that each these works are archived. ${ }^{303}$

Such participatory recommendations were likewise documented in a 1954 report written by J. Roby Kidd on behalf of the Canadian Film Archive Committee, which advocated that filmmakers themselves become partially responsible for financing the preservation of their own work. For in the process of complying with such requests to archive titles, independent producers must search for original elements, contend with questions from the archives and the labs, supply the archives

allow for permanent dedicated staffing, which might equate with long-term planning and a comprehensive strategy to accommodate older films missing from the vaults.

${ }^{301}$ Independent filmmakers may content themselves with the notion that their work will be held in perpetuity for future generations, though with current migration issues and consistent debates over access to archival works, this is perhaps of little consolation to cash strapped independent producers. It also must be underscored that just because a work is archived does not mean that it will be publicly accessible. For more information on access conditions, please refer to the website of Library and Archives Canada: www.collectionscanada.ca.

302 Government of Canada, Department of Canadian Heritage, From Script to Screen, p. 8.

${ }^{303}$ Essentially, before independent producers qualify to receive their final draw-down payment from Telefilm, they must provide Telefilm Officers with a letter from LAC that states that all of the LAC deliverables cited in the financial contract have been met. Depending on their budgets, producers give LAC copies of their work in variable formats: in addition to DVD copies and key credit 
with key descriptive information, and become ultimately responsible for insuring their until these preservation initiatives are complete. Nevertheless, the fund has only inadvertently redirected small amounts of money toward the acquisition of shorts at LAC. ${ }^{304}$ As it currently stands, there still remains no systematic means by which to safeguard the bulk of independently produced short-form work, including that produced through the funding mechanisms of the Media Arts Sector within the Canada Council for the Arts, itself a government agency.

In summation, Chapter Three has moved through several of the key issues at stake in terms of preserving independently produced audiovisual documents, as circumscribed within federal policy development in Canada throughout the $20^{\text {th }}$ century. While it is now clear that audiovisual records are indeed suitable contributions to national cultural heritage, the types of audiovisual works chosen to inform history remain at the mercy of shifting institutional priorities, as they are subjected to the vagaries of acquisition policy, selection criteria and the penultimate, political will. Although it is beyond the scope of this thesis to expand upon the much contested ground that has informed the development of acquisition policy, or the evolution of selection criteria as this has shifted over the past century, it is clear that a substantial contribution of financial and human resources would be required for the ongoing, systematic preservation of independently produced Canadian media artworks. The longevity of these works, and therefore their contribution to Canadian

lists, budgets over $\$ 1$ million demand the deposit of two film prints, while production companies with budgets under this need only deposit Digital Betacam clones.

304 The annual acquisition budget for short-form work varies considerably from year to year; between 2004 and 2008 the budget shifted from as little as $\$ 12,000$ to a maximum of $\$ 30,000$. 
history, remains subject to the political will of shifting federal governments and that of the national institutions entrusted with policy development on behalf of Canadian culture. Consequently, the preservation of independently produced media artwork, as supported by the Canada Council for the Arts, has fallen into gaps ungoverned by those Canadian federal policies that are designed to secure our preservation infrastructure, and thus inform the future of our cultural heritage. 


\section{Conclusions}

This thesis has woven a picture of the Canadian cultural milieu that encapsulates the evolution of the independent film and media arts communities in tandem with Canadian audiovisual archival policy, so as to show how the survival of audiovisual history is enmeshed within federal cultural policy developments that have served the Canadian cultural arena in the $20^{\text {th }}$ century. Carole Sklan states, "Film culture is the aesthetic, the political, the economic, and the social ... a creative interaction between the films and the vitality of the culture from which they emerge." 305 And while this thesis does not focus on the aesthetics of specific films, or the influence of the conceptual art movement on the development of video art, for example, it does underscore that without access to the actual work produced by the independent media arts community, there can be no such creative interaction with legacy work, no demonstrable vitality for historians who seek to study the role of Canadian media art culture, nor a public who might wish to enjoy it.

Further, because of the nature of contemporary technology and its underpinnings, without adequate governance and a systematic strategy to serve a cohesive preservation infrastructure, the history embedded within independent Canadian media productions is on the verge of becoming obsolete. Canadians may soon be left without the capacity to acknowledge or appreciate the contribution that this cultural community has made to our collective heritage, and certainly, the artistic community itself will be left without the ability to fully trace its own presence.

\footnotetext{
${ }^{305}$ Sklan, p. 236.
} 
This thesis has outlined how certain early filmmaking practices were supported through government institutions (film tags, newsreels and documentaries), while other work (commercial, dramatic and artistic) was essentially considered independent, in that it existed beyond government patronage. Federal cultural policy did not address these independent filmmakers and a as a direct consequence, only some of their creative output was eventually preserved, that work seen as particularly useful to the historic nation-building exercise, which included: war footage, as was kept for reuse within the War Office Archives; newsreels, such as those first moving images gathered at Public Archives Canada; and, select government-sponsored publicity films that promoted Canada internationally. Film was not seen as cultural product in and of itself, so very little independently produced dramatic or artistic works remain accessible from the formative era of Canadian cultural history, largely because neither the federal government nor archival institutions placed any value on this type of work; it was not yet seen as a significant contribution to Canadian heritage.

Certainly, the thesis also demonstrated that by the middle of the $20^{\text {th }}$ century, the Canadian cultural community was indeed overwhelmed by the socio-economic and political repercussions of benign federal policies, which had resulted in a free market mentality around independent film work that left commercial producers open to the forces of foreign cultural imperialism, while an aura of elitism had left artists at the mercy of scant resources beyond waning arts patronage. Importantly, without a federal policy infrastructure that might have tended to the respective needs of the fractured cultural community, the means by which to reach their goals, whether that 
be to augment cultural output or create meaningful networks to foster awareness and/or market indigenous film and art, remained unattainable; needless to say, preservation was not a high priority for most. Even the development of policies that established certain means of production and distribution, then mandated that first the National Film Board preserve, and then that the Canada Council conserve, did not produce internal institutional policies that reallocated the resources necessary to vital archival practices. Subsequent policies within Canada's national cultural institutions, including the National Gallery of Canada, the Canada Council and Public Archives Canada, have not ensured the survival of independently produced contributions to Canadian audiovisual heritage. The lack of political will to provide adequate governance and enable a preservation framework that would systematically support the unique physical needs of moving image materials has meant that only a small percentage of primarily government-funded audiovisual records from the $20^{\text {th }}$ century will survive into the future.

It is indeed tempting to surmise that the audiovisual production and developmental administrative history of independent media-based producers, including that of artist-run culture, is doomed to obscurity. The cultural community of independent media production in Canada has morphed into distinct sectors, now served by policy from the Canadian government, which is administered through the bureaucracy of institutions including the Canada Council for the Arts, Telefilm Canada, the NFB and the CBC. Yet the powerful, early activism that once shaped the community, including the establishment of the Independent Media Art Alliance and the Media Art Sector at Canada Council, has remained largely ineffective in face of 
an unresponsive ad-hoc preservation environment replete with wavering political will. The Canada Council is not working to salvage that part of its own history. Indeed, the Canada Council, while honouring its founding spirit of nationalism by neatly overlapping provincial-national/cultural-educational dichotomies, can be said to have remained only partially true to its mandate. For to 'foster and promote the study and enjoyment' of cultural works produced through Council funding means that future generations of artists, distributors and exhibitors must have the means by which to access, across time, the actual audiovisual works that have been produced through generations of public funding. So while independent media art culture has evolved to now garner the financial support needed to secure production and dissemination avenues, this in itself cannot sustain the vitality of this nation-wide cultural community network - contemporary media artwork must be preserved under careful climactic conditions, and legacy work must be migrated to more suitable contemporary formats, if any of it is to survive into the future.

Of course, the very late and reluctant acceptance of audiovisual material within archival circles in Canada resulted in grave critical mass - quite simply, by the time political will enabled the provision of resources necessary to sway internal institutional goals within the nation's archive, there were far too many moving image records in desperate need of salvation. In fact, as Chapter Three has demonstrated, even contemporary preservation policy that governs the establishment of prospective media-based collections at Library and Archives Canada is as indelibly linked to changeable federal cultural policy now as it has been in the past. The overall result, unfortunately, has yielded the retention of only a smattering of early independent 
audiovisual works and produced only very recent attempts to systematically preserve independently produced feature-length work, the funding for which itself may now be at risk of disappearing. All of which still leaves the short-form work produced through the independent media art sector without archival shelter.

What are the key issues for contemporary media artists working within artistrun culture? Undoubtedly, independent media artists want access to their work throughout the lifetime of the creator; they also want reuse, circulation and proper storage for contemporary and legacy work, in as much as early film practitioners had themselves desired. Artists work within living culture, and they rightfully demand economic recompense for their efforts, the right to foster a professional reputation, to create awareness around their own fonds, and to assure professional career development. That is how they will also secure a place for themselves in history. Ironically, it is this same history that is at risk, for without a preservation infrastructure, contemporary media artwork will never become part of an archival legacy. And while artists haven't always cared to endear themselves to institutions such as Library and Archives Canada, or even the National Gallery of Canada, both of which have been seen as "undemocratically structured, denying to artists' control over their activities [so as to] devalue the historical significance and social effectiveness of the artwork," 306 those very institutions must now be moved to care about the preservation and archival care of contemporary and legacy independent media artworks, if these works are to endure.

${ }^{306}$ Gary Kibbins, quoted in Robertson, p. 14. 
As Foucault suggests, the mechanisms of bureaucratic power refer "as much to the how of power as to who has power within alternative and mainstream art and cultural organizations. ${ }^{307}$ What, therefore, is the role of the Independent Media Arts Alliance in determining a future for its members, both organizational and individual? For the moment, IMAA has begun work to produce Best Practices Guidelines, to encourage artists and artist-run centres to follow basic preservation practices that will insure the immediate future of contemporary audiovisual works. But in no way will this alleviate the crisis that has befallen the legacy of work produced through its membership network.

IMAA may, however, be able to also reinvest its membership with the former power of authority they collectively wielded in the 1970s, and in the process, reposition itself as a strong and effective lobby group within a well-oiled, yet disjointed, federal cultural infrastructure. With a national membership, IMAA is, after all, a National Arts Service Organization, and therefore part of a much larger "federal machinery of political representation." ${ }^{308}$ IMAA exists both within and beyond the federal bureaucratic infrastructure that controls funding to its member groups and indeed, it would not be the first time that the Canada Council has been challenged through this national forum, which is mandated to lobby on behalf of all Canadian media arts centres. ${ }^{309}$ With the power of an abundant, activist national network,

${ }^{307}$ Robertson, p. iii.

${ }^{308}$ Robertson, p. 6.

${ }^{309}$ Anti-racism strategies created through the activism of collectives that established themselves through the network of artist-run centres in the early ' 90 s continue to shape equity policies, both within IMAA and at the Canada Council; such policies, which were once paid mere lip-service, are now visibly effective and healthily embraced. For a full description of certain such developments, the reader is encouraged to consult Robertson, Chapter 2, pp. 36-40. 
IMAA is well-positioned to lobby for the redress of such pertinent preservation issues; consequently, the membership should itself be able to invigorate debate within the Canada Council.

With significant pressure from within IMAA, the Canada Council would be made to feel the full weight of the preservation crisis, which is slowly erasing the history of independent media arts producers and artist-run culture in general, the very community Council has worked so hard to foster. Council is, in turn, well positioned to address these vital preservation issues from within its own bureaucratic hierarchy, that is, at the level of the federal government and within the Department of Canadian Heritage, who also oversee certain aspects of preservation within Library and Archives Canada. At the very least, Council might provide internal governance on behalf of the independent media arts community, first by closely examining the issues and subsequently, by instigating discussions that could exert the necessary influence within the infrastructure of federal cultural institutions to which Council belongs, a network of policy makers whose awareness is crucial to the survival of Canadian cultural audiovisual heritage.

At InFest in 2004, an international conference attended by representatives from artist-run centres across the world, the Head of the Visual Arts Section, François Lachapelle, spoke on behalf of the Canada Council, a major funder of the event. He stated that "the future of artist's centres in Canada is tied to their capacity to be more than alternate [or] parallel. They must locate themselves in the Canadian 
imagination in terms of their own public authority." ${ }^{310}$ To do so, the community of independent media arts organizations does need to become less acquiescent, and perhaps even less dependent upon the federal hand that feeds them. Yet in order to remain in the imagination of the Canadian public, the preservation crisis must also be averted, for in the long run, Canadian historians, theorists and artists must have access the audiovisual work as well as the administrative records of the organizations that have been created to produce them. Certainly, the Canada Council must understand this at its most base level.

So perhaps, in order to rally the resources so vital to the preservation of independent media art and the cultural heritage ensconced within this community, it is again time to expose "the movement's weak investments in its own project of selfdetermination." 311 The fact is, artist-run culture deserves to know itself, so it should be sure it can locate itself within the holdings of archival institutions designed to protect heritage audiovisual works and the administrative history behind such government funded cultural organizations. Certainly, Canada's public institutions; the Canada Council for the Arts, Library and Archives Canada, and their governor, the Department of Canadian Heritage, should be bound by duty to facilitate such historical access on behalf of the Canadian people. To draft policy that would accommodate the independent media arts within the current archival infrastructure, or otherwise reallocate necessary resources within these key institutions to provide for a systematic preservation infrastructure, would finally accomplish a task that has

\footnotetext{
${ }^{310}$ Lachappelle quoted in Robertson, p. 7.

311 Robertson, p. 19.
} 
for too long been ignored. Otherwise, the history of the independent media arts community will indeed fade away.

Thus, this thesis has established the historic cultural policy trajectory that has led to the audiovisual preservation crisis within the independent media arts community, because understanding its complexity is critical to the successful development of a contemporary strategy that will finally address the key issues at hand, for all of the players. And while this thesis also serves to establish a foundation for further scholarship grounded in cultural policy as has affected the emergence of the independent media arts community in Canada, it is hoped that this past will also hold the key that will enable critical discourse in a future that contains the collective works produced by the independent media arts community 


\section{Bibliography}

Abbott, Jennifer, ed. Making Video 'In': The Contested Ground of Alternative Video on the West Coast. Vancouver: Video In Studios, 2000.

Audio-Visual Preservation Trust. http://www.avpreservationtrust.ca

Backhouse, Charles. Canadian Government Motion Picture Bureau, 1917-1941.

Ottawa: Canadian Film Institute, 1974.

Bordwell, David, and Kristin Thompson. Film History: An Introduction. New York: McGraw-Hill, 1993.

Bumsted, J. M.. Interpreting Canada's Past. Toronto: Oxford Press, 1986.

Canada Council for the Arts. http://www.canadacouncil.ca

- Electronic Media Programme: Policy Report with Recommendations. Research \& Evaluation, Ottawa, 1977.

_ Policy Options for the '80's. Research \& Evaluation, Ottawa, 1980.

The Arm's Length Principle and the Arts: An International Perspective Past, Present and Future. Research \& Evaluation, Ottawa, 1985.

Media Arts 1985: A Brief History of the Development of Media Arts. Media Arts Section, Ottawa, 1985.

- Trends in Support to the Arts - Technical Tables, $10^{\text {th }}$ Edition. Research \& Evaluation, Ottawa, February 1990.

_ Artists' Centres: A Twenty Year Perspective, 1972-1992. Visual Arts Section, Ottawa, September 1993.

Canadian Film Institute. November 1979.

Cinema Canada, Second Edition, no. 3, (July/August 1972).

Third Edition, no. 26, (March 1976).

Diamond, Sara. "Turn that Camera Inside Out: Some Thoughts on Synaesthesia." In Abbott, Making Video 'In': 63-88.

Dorland, Michael. So Close to the States: The Emergence of Canadian Feature Film Policy. Toronto: University of Toronto Press, 1998. 
Edmonson, Ray. "Audiovisual Archiving: Philosophy and Principles." In Recommendations for the Safeguarding and Preservation of Moving Images. Paris: UNESCO, 2004.

Ellis, Jack. John Grierson: Life, Contributions, Influence. Carbondale: Southern Illinois University Press, 2000.

Evans, Gary. John Grierson and the National Film Board: The Politics of Wartime Propaganda, 1939-1945. Toronto: University of Toronto Press, 1984.

Forster, Audrey. "From the CPR to the Canada Council." In A Celebration of Canada's Arts, 1930-1970, edited by Glen Carruthers and Gordana Lazarevich. Toronto: Canadian Scholar's Press Inc., 1996: 213-225.

Fortier, André, and Paul Schafer. Development and Growth of Federal Arts Policies in the Arts, 1944-1985. Ottawa: Department of Communications, 1985.

Gagné, Raymond. "French Canada: The Interrelationship between Culture, Language and Personality." In Canadian History Since Confederation: Essays and Interpretations, edited by Bruce Hodgins and Robert Page. Georgetown, Ontario: Irwin-Dorsey, 1972: 521-540.

Gale, Peggy. "Distribution in a Wider Context", in Canada Council for the Arts, Electronic Media Programme: Policy Report with Recommendations, 47-9.

Goldberg, Michael. "Before the Generation Loss: the Early Years of Video." In Abbot, Making Video 'In', 33-44.

Government of Canada, Department of Communications, Report of the Federal Cultural Policy Review Committee. Ottawa: Minister of Supply and Services Canada, 1982.

- National Archives of Canada, Fading Away: Strategic Options to Ensure the Protection of and Access to our Audio-Visual Memory. Ottawa: National Archives Canada, 1995.

_- Department of Canadian Heritage, From Script to Screen: New Policy Directions for Canadian Feature Film. Ottawa: Minister of Public Works and Government Services Canada, 2000.

- http://www.pch.gc.ca

— http://laws.justice.gc.ca/en/C-2/text.html 
Granatstein, J. L.. "Culture and Scholarship: The First Ten Years of the Canada Council." Canadian Historical Review LXV 4. Toronto: University of Toronto Press, 1984: 441-474.

Hackett, Yvette. "The National Film Society of Canada, 1935-1951: Its Origins and Development." In Flashback: People and Institutions in Canadian Film History, edited by Gene Walz. Montreal: Media Text Publications Inc., 1986: 135-165.

Hardy, Forsyth. John Grierson: A Documentary Biography. London: Faber \& Faber, 1979.

Harvey, Andy. "Community Video Library," in Canada Council for the Arts, Electronic Media Programme: Policy Report with Recommendations, 25-6.

Hill Times, The. http://www.thehilltimes.ca/html.

Independent Media Arts Alliance. http://www.imaa.ca

_ "Structure Committee Report: Proposed Structure for Affiliation,"(presented to the Yorkton Independent Film Conference, November 1980).

"Meeting to Discuss a National Association of Filmmakers,"(presented by the Atlantic Region, n.d.).

— "By-laws of the Independent Film Alliance du Cinéma Indépendent" (March 20, 1981).

Jarvie, Ian. "National Cinema: A Theoretical Assessment." In Cinema and Nation, edited by Mette Hjort and Scott MacKenzie. London: Routeledge, 2000: 75-87.

Johnson, Mary M.. "The Federal Government and the Politicization of the Canada Council: Exploring the Fine Line Between Accountability and Interference." Master's thesis, Carleton University, 2000.

Kula, Sam. The Archival Appraisal of Moving Images: A RAMP Study with Guidelines. Paris: UNESCO, 1983.

Lemieux, David. "A Film Archive for Canada." The Moving Image, Spring 2002: 1-23.

Lemieux, René, and Joseph Jackson. The Arts and Canada's Cultural Policy. Ottawa: Parliamentary Research Branch, Political and Social Affairs Division, 1999. 
Library and Archives Canada. http://www.collectionscanada.ca

Litt, Paul. The Muses, the Masses and the Massey Commission. Toronto: University of Toronto Press, 1992.

"The Massey Commission as Intellectual History: Matthew Arnold Meets Jack Kent Cooke," Canadian Issues/Themes Canadiens: Practicing the Arts in Canada, Vol. XII, Montréal: 1990: 23-34.

Magder, Ted. Canada's Hollywood: The Canadian State and Feature Films. Toronto: University of Toronto Press, 1993.

Marchessault, Janine. "Amateur Video and Challenge for Change." In Mirror Machine: Video and Identity, edited by Janine Marchessault. Toronto: YYZ Books, 1995: 13-25.

Moving Image Collections (MIC). http://mic.imtc.gatech.edu/preservationists portal/presv timeline.htm

Milligan, Frank. "The Ambiguities of the Canada Council." In Love and Money: The Politics of Culture, edited by David Helwig. Ottawa: Oberon Press, 1980: 60-89.

Meisel, John, and Jean Van Loon. "Cultivating the Bushgarden: Cultural Policy in Canada." In The Patron State: Government and the Arts in Europe, North America, and Japan, edited by Milton C. Cummings, Jr. and Richard S. Katz. New York: Oxford University Press, 1987: 276-310.

Morris, Peter. Embattled Shadows: A History of Canadian Cinema, 1895-1939. Montreal: McGill-Queens University Press, 1978.

National Archives of Canada, Ottawa. Documents that Move and Speak: Audiovisual Archives in the New Information Age. Edited by Richard Lochead. Müchen: K.G. Saur, 1980.

__ Fading Away, VHS, 1995.

—W Wanda Noël. Staff Guide to Copyright. Her Majesty the Queen in Right of Canada, 1999.

Jean-Pierre Wallot. The Preservation and the Enhanced Use of our Canadian Audio-Visual Heritage: A Passing Heritage. December 1993.

National Gallery of Canada. www.gallery.ca 
Pelletier, Gerard. "Canada's Film Policy: The First Phase." In Cinema Canada. Second Edition, no. 3 (July/August 1972): 6-7.

Public Archives Canada, Annual Report, 1959-1969. Ottawa, 1971.

Annual Report, 1976-77. Ottawa, 1977.

National Film, Television and Sound Archives, General Guide Series 1983.

Ottawa: Canada: Minister of Supply and Services, 1983.

- Canadian Feature Film Index: 1913-1985. D.J. Turner and Micheline Morisset. Ottawa: Minister of Supply and Services Canada, 1987.

Robertson, Brian. "Feature Film Policy - Some Comments." Alliance for Canada's Audio-Visual Heritage, March 1998.

http://www.pch.gc.ca/progs/ac- ca/pol/cinema-film/pubs/sub78.htm

Raboy, Marc. Missed Opportunities: The Story of Canada's Broadcasting Policy. Montréal: McGill-Queens University Press, 1990.

Robertson, Clive. Policy Matters: Administrations of Art and Culture. Toronto: YYZ Books, 2006.

Sklan, Carole. "Peripheral Visions: Regionalism, Nationalism, Internationalism." In Film Policy: International, National and Regional Perspective, ed. Albert Moran. New York: Routeledge, 1996: 234-248.

Telefilm Canada. http://www.telefilm.gc.ca.

Thompson, John, and Allen Seager. Canada, 1922 - 1939: Decades of Discord. Toronto: Toronto University Press, 1985.

Tippett, Maria. "'A Mad Desire to Bring About State Control': Government Patronage and the Arts," in Making Culture: English-Canadian Institutions and the Arts before the Massey Commission. Toronto: University of Toronto Press, 1990: 63-91.

— "The Origins of the Canada Council: 'The Most Generous Sugar Daddy Art Has Ever Known'." In Probing Canadian Culture, edited by Peter Easingwood, Konrad Gross and Wolfgang Kloos. Augsburg: AV-Vert, 1991: 38-51.

Villeneuve Media Technologies. The Canadian A-V Vault Inventory Report. Audio-Visual Preservation Trust, 2003. http://www.avpreservationtrust.ca 
Video Art in Canada. http://www.videoart.virtualmuseum.ca

Vipond, Mary. "The Nationalist Network: English Canada's Intellectuals and Artists in the 1920s," Canadian Review of Studies in Nationalism, Vol. 5.1, Spring 1980: 32-52.

Wise, Wyndham. Take One's Essential Guide to Canadian Film, September, 2001.

Wong, Paul. "Concepts and Potentials for Video Exchange," in Canada Council for the Arts, Electronic Media Programme: Policy Report with Recommendations, 28-31.

Wozny, Michele L. "An Introduction to Media Arts Preservation Initiatives in Canada." Unpublished research paper commissioned by the Canada Council for the Arts, Ottawa, August, 2005: 30-31.

— "National Audiovisual Preservation Initiatives and the Independent Media Arts in Canada," Archivaria, no. 67, 2009: 97-113.

Zuzanek, Jiri. "Democratization of Culture and Cultural Democracy in Canada," In Funding the Arts, Vol. 1. Edited by H. H. Chartrand, H. S. Hendon, and H. Horowitz. Avignon, France: February, 1987: 115-121. 